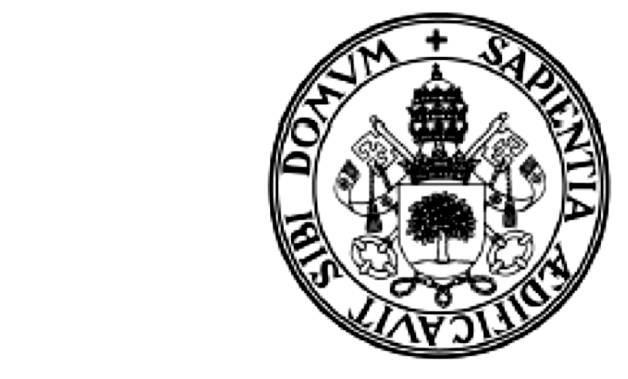

UNIVERSIDAD DE VALLADOLID

ESCUELA DE INGENIERÍAS INDUSTRIALES

\author{
DEPARTAMENTO DE INGENIERÍA QUÍMICA Y \\ TECNOLOGÍA DEL MEDIO AMBIENTE
}

\title{
NITROGEN REMOVAL IN DOMESTIC WASTEWATER AFTER ANAEROBIC TREATMENT
}
Presentada por Lara Pelaz Pérez para optar al grado de Doctor por la Universidad de Valladolid

Dirigida por:

Prof. Dra. María Fdz-Polanco Íñiguez del la Torre 



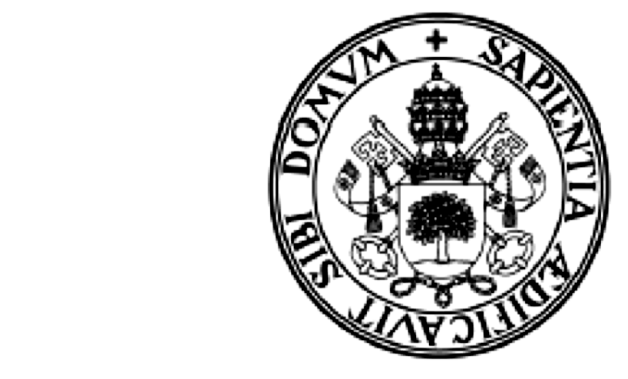

UNIVERSIDAD DE VALLADOLID

ESCUELA DE INGENIERÍAS INDUSTRIALES

\author{
DEPARTAMENTO DE INGENIERÍA QUÍMICA Y \\ TECNOLOGÍA DEL MEDIO AMBIENTE
}

\title{
ELIMINACIÓN DE NITRÓGENO EN AGUAS RESIDUALES \\ DOMÉSTICAS DESPUÉS DE TRATAMIENTO ANAEROBIO
}

\author{
Presentada por Lara Pelaz Pérez para optar al grado de Doctor \\ por la Universidad de Valladolid
}

Dirigida por:

Prof. Dra. María Fdz-Polanco Íñiguez del la Torre 

Memoria para optar al grado de Doctor, presentada por la Ingeniera Química

Lara Pelaz Pérez

Siendo la tutora en la Universidad de Valladolid

Dra. Dạ María Fdz-Polanco Íñiguez de la Torre

Valladolid,

de de 2016 

UNIVERSIDAD DE VALLADOLID

ESCUELA DE INGENIERIAS INDUSTRIALES

\section{Secretaría}

La presente tesis doctoral queda registrada en el folio número del correspondiente libro de registro número

Valladolid,__ de ___ de 2016

Fdo. El encargado de registro 



\section{María Fdz-Polanco Îniguez de la Torre}

Profesora Titular de Universidad

Departamento de Ingeniería Química y Tecnología del Medio Ambiente Universidad de Valladolid

Certifican:

Que la ingeniera química LARA PELAZ PÉREZ ha realizado bajo su dirección el trabajo "Nitrogen removal in domestic wastewater after anaerobic treatment", en el Departamento de Ingeniería Química y Tecnología del Medio Ambiente de la Escuela de Ingenierías Industriales de la Universidad de Valladolid. Considerando que dicho trabajo reúne los requisitos para ser presentado como Tesis Doctoral expresa su conformidad con dicha presentación.

Valladolid,__ de ___ de 2016

Fdo. María Fdz-Polanco íñiguez del la Torre 

Reunido el tribunal que ha de juzgar la tesis doctoral titulada "Nitrogen removal in domestic wastewater after anaerobic treatment" presentada por la ingeniera Lara Pelaz Pérez y en cumplimiento con lo establecido en el Real Decreto 99/2011 de 28 de enero de 2011 ha acordado conceder por la calificación de

Valladolid, a de de 2016 

Reunido el tribunal que ha juzgado la Tesis Doctoral titulada "Nitrogen removal in domestic wastewater after anaerobic treatment" presentada por la Ingeniera Química Lara Pelaz Pérez y en cumplimiento con lo establecido en el Real Decreto 1393/2007 de 29 Octubre ha acordado conceder por la calificación de

Valladolid, a de de 2016 
A mis padres, Silvio y Ma Rosa 
Contents

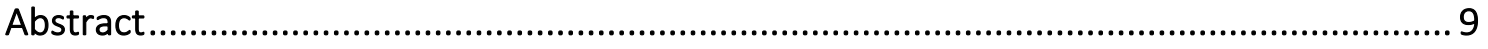

Resumen

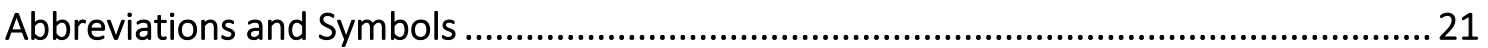

Chapter 1: State of the Art. Nitrogen removal in domestic wastewater after anaerobic

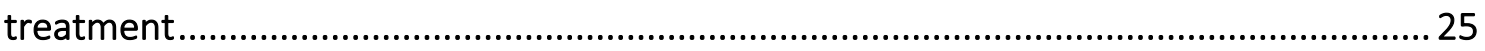

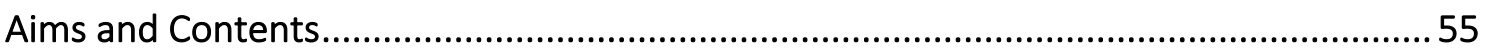

Chapter 2. SBR system for nitrogen removal in domestic wastewater from anaerobic treatment. 61

Chapter 3. Denitrification of the AnMBR effluent with alternative electron donors in domestic wastewater treatment.

Chapter 4. Advanced denitrification of anaerobic treatment effluent of domestic wastewater by using wasted gas. 101

Chapter 5. Nitrogen removal in domestic wastewater. Effect of the nitrate recycling and the $\mathrm{COD} / \mathrm{N}$ ratio.

Chapter 6. Techno-economical study of a domestic wastewater treatment system.... 137

Conclusions 159

Agradecimientos. 165

Acknowledgements 165 
Contenido

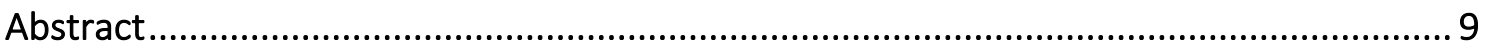

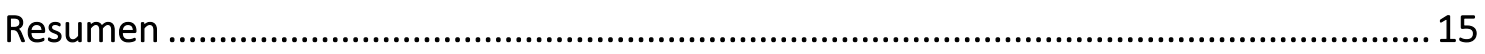

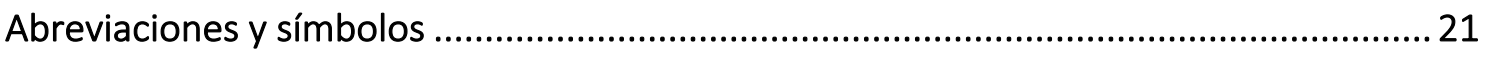

Capítulo 1: Estado del arte. Eliminación de nitrógeno en aguas residuales domésticas

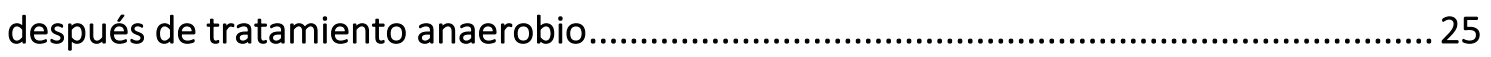

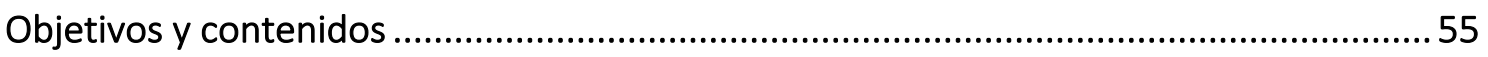

Capítulo 2: Sistema SBR para eliminación de nitrógeno en aguas residuales domésticas después de tratamiento anaerobio.

Capítulo 3: Desnitrificación del efluente de un AnMBR con dadores de electrones alternativos en aguas residuales domésticas.

Capítulo 4: Desnitrificación avanzada del efluente de tratamiento anaerobio utilizando gas usado 101

Capítulo 5: Eliminación de nitrógeno en aguas residuales domésticas. Efecto de la recirculación de nitratos y de la relación $\mathrm{DQO} / \mathrm{N}$.

Capítulo 6: Estudio tecno-económico de un sistema de tratamiento de aguas residuales domésticas.

Conclusiones 159

Agradecimientos. 165

Acknowledgements 165 


\section{Abstract}

Nitrogen removal in domestic wastewater after anaerobic treatment 
Domestic wastewater contains excessive nutrients, harmful bacteria/viruses and household chemicals that may contaminate the land and waters and threaten public health. Therefore, before the domestic wastewaters discharge, it will be necessary a treatment to prevent diseases in people, and to protect the fauna and flora present in the natural receptor body. Wastewater treatment is closely related to the standards set for the effluent quality.

Anaerobic technology for organic matter removal is very favorable under the perspective of sustainable development. However, the anaerobic effluent usually requires a post-treatment step as a means to adapt the treated effluent to the requirements of the environmental legislation and protect the receiving water bodies. The main role of the post-treatment is to eliminate the nutrients and complete the removal of organic matter.

For the biological removal of organic matter and nitrogen, anaerobic, anoxic and aerobic biological processes should be combined. For this purpose, different treatment systems are being developed to maximize the advantages of both aerated and non-aerated processes.

The aim of this PhD Thesis is to develop and evaluate different treatment processes of an anaerobic reactor effluent fed with domestic wastewater. For this purpose, different reactor configurations are developed: SBR and biofilters, with different reaction ways to treat the effluent of an anaerobic reactor. Nitrogen removal efficiency and environmental sustainability have been considered to comply the discharge standards in domestic wastewater.

In Chapter 2, this work presents the performance of a sequencing batch reactor (SBR) system used as nitrogen removal treatment of domestic wastewater previously treated with an anaerobic reactor and as consequence, with a low $\mathrm{C} / \mathrm{N}$ ratio. The aim of the work was to determine the feasibility for the removal of nitrogen from the domestic wastewater. A $5 \mathrm{~L}$ of working volume SBR was investigated at different cycle times of $12 \mathrm{~h}, 8 \mathrm{~h}$ and $6 \mathrm{~h}$, at $18{ }^{\circ} \mathrm{C}$. The treatment efficiency of SBR varied with the duration of the cycle time, being optimal the anoxic/aerobic/anoxic sequence cycle with $6 \mathrm{~h}$ of duration. Due to the low organic matter present in the domestic wastewater after anaerobic treatment, an additional supply of external carbon before the second anoxic stage was necessary. The addition of methanol was a key point in the denitrification process employed as a model for the wastewater by-pass in wastewater treatment plants (WWTP). The removal efficiencies obtained were: $98 \%$ for TKN, $84 \%$ for total nitrogen and $77 \%$ for soluble COD. The reactor showed viability, so this process can be successfully applied as a post-treatment of an anaerobic reactor treating domestic wastewater, for the removal of nitrogen. 
In Chapter 3, the performance of a fixed film bioreactor for partial and total denitrification of the effluent from an anaerobic membrane bioreactor (AnMBR) treating domestic water was investigated. Wastewater after anaerobic treatment, with a low $\mathrm{C} / \mathrm{N}$ ratio, contains a remaining COD which is not enough for the conventional heterotrophic denitrification. As the effluent from the low-temperature anaerobic reactor holds methane and sulfide dissolved and oversaturated, it was evaluated the feasibility of using these reduced compounds as electron donors to remove $80 \mathrm{mg} \mathrm{NO}{ }^{-}-\mathrm{N} / \mathrm{L}$ at different $\mathrm{HRT}$ obtaining the optimum at $2 \mathrm{~h}$. In addition, the influence of the $\mathrm{NO}_{2}{ }^{-} / \mathrm{NO}_{3}{ }^{-}$ratio $(100 \% / 0 \% ; 50 \% / 50 \% ; 25 \% / 75 \%$ and $0 \% / 100 \%)$ in the feed was studied. Satisfactory results were obtained achieving total nitrogen removal in the denitrifying effluent, being aware of the case with $100 \% \mathrm{NO}_{3}{ }^{-}$in the feed, that was at the limit of the process. Methane was the main electron donor used to remove the nitrites and nitrates, with more than $70 \%$ of participation.

In Chapter 4, a pilot plant of denitritation was operated for more than five months treating domestic wastewater with high ammonium nitrogen concentration from anaerobic process under ambient temperature conditions ( $18 \stackrel{\circ}{\circ}$ ). The process consisted on one biofilter with $2 \mathrm{~h}$ of HRT for denitritation. To study the feasibility of the denitritation process, different synthetic nitrite concentrations were supplied to the anoxic reactor to simulate the effluent of a nitritation process. The present work investigates an advanced denitritation of wastewater using the organic matter and other alternative electron donors from an anaerobic treatment: methane and sulfide. The denitrifying bacteria were able to treat water at an inlet nitrite concentration of $75 \mathrm{mg} \mathrm{NO}{ }_{2}^{-}-\mathrm{N} / \mathrm{L}$ with removal efficiency of $92,9 \%$. When the inlet nitrite concentration was higher it was necessary to recirculate the gas obtained in the anoxic reactor to enhance the nitrite removal, achieving $98,3 \%$ of $\mathrm{NO}_{2}{ }^{-}$elimination efficiency.

In Chapter 5, a denitrification/nitrification pilot plant was designed, built and operated to treat the effluent of an anaerobic reactor. The plant was operated to examine the effect of the nitrate recycling and the $\mathrm{C} / \mathrm{N}$ ratio on the nitrogen and the remaining organic matter removal. The system consisted of a two stages treatment process: anoxic and aerobic. The HRT of the system was $2 \mathrm{~h}$ for the anoxic bioreactor and $4 \mathrm{~h}$ for the aerobic one. The increase in the nitrate recycling ratio did not suppose a significant improvement in the nitrogen removal due to the insufficient carbon source. The wastewater to be treated had a $\mathrm{C} / \mathrm{N}$ ratio of 1.1 showing a lack of organic carbon. The addition of methanol was a key point in the denitrification process employed as a model for the traditional wastewater by-pass in the WWTP. The maximum 
nitrogen and organic matter removal ( $84.7 \%$ and $96 \%$, respectively) was achieved with a nitrate recycling ratio of $600 \%$ and a $\mathrm{C} / \mathrm{N}$ of 8.25 , adjusted by methanol addition.

In Chapter 6, the techno-economical feasibility of the membrane anaerobic treatment of wastewater eliminating nitrogen has been simulated. The process was simulated using experimental data analyzing the influence of different electron donors (methane, organic matter and sulfide) on the nitrogen elimination capacity. Different scenarios have been assessed changing the concentration of the involved components and evaluating their effect on the nitrogen elimination capacity as well as the ability to produce biogas in the anaerobic treatment. These scenarios imply on the one hand, the increment of the available soluble COD for the nitrogen elimination stage. The COD feed to the reactor was adjusted at values between $15 \%$ and $30 \%$ assuming different mixing ratios with the influent stream of the anaerobic reactor. On the other hand, different flows of biogas from the anaerobic reactor were pumped to the denitritation reactor. The goal was to achieve a nitrogen elimination capacity to reach an effluent with $10-20 \mathrm{mg} \mathrm{N} / \mathrm{L}$. Then, the most promising scenario was studied in detail and it was compared to the costs associated to the WWTP with a biological anaerobic treatment using a MBR system. The results indicated that the proposed process is feasible since the fixed and variables costs of both treatment plants are similar. 


\section{Resumen}

Eliminación de nitrógeno

en aguas residuales domésticas

después de tratamiento anaerobio 
Las aguas residuales domésticas contienen un exceso de nutrientes, bacterias/virus dañinos y sustancias químicas domésticas que puedan contaminar la tierra y el agua y poner en peligro la salud pública. Por lo tanto, antes de la descarga de aguas residuales domésticas, es necesario un tratamiento para prevenir enfermedades en las personas, así como para proteger la fauna y la flora presente en el cuerpo receptor natural. El tratamiento de aguas residuales está estrechamente relacionado con las normas establecidas para la calidad del efluente.

La tecnología anaerobia para la eliminación de materia orgánica es muy favorable desde el punto de vista del desarrollo sostenible. Sin embargo, el efluente anaerobio generalmente requiere una etapa de post-tratamiento para adaptar el efluente tratado a los requisitos de la legislación ambiental y proteger los cuerpos de agua receptores. El papel principal del posttratamiento es eliminar los nutrientes y completar la eliminación de la materia orgánica.

Para la eliminación biológica de la materia orgánica y nitrógeno, los procesos biológicos de tratamiento anaerobio, anóxico y aerobio deben combinarse. Para este propósito, están siendo desarrollados diferentes sistemas de tratamiento para maximizar las ventajas de ambos procesos aerobios y no aerobios.

El objetivo de esta tesis doctoral es desarrollar y evaluar diferentes procesos de tratamiento del efluente de un reactor anaerobio alimentado por aguas residuales domésticas. Para este propósito, se han desarrollado diferentes configuraciones de reactor: SBR y biofiltros, con diferentes caminos de reacción para tratar el efluente de un reactor anaerobio. Para acatar las normas de descarga de aguas residuales domésticas, se han considerado la eficiencia de eliminación de nitrógeno y la sostenibilidad ambiental.

En el capítulo 2, se presenta el rendimiento de un reactor discontinuo secuencial (SBR), utilizado como tratamiento para la eliminación de nitrógeno de las aguas residuales domésticas previamente tratadas con un reactor anaeróbico y, como consecuencia, con una baja relación $\mathrm{C} / \mathrm{N}$. El objetivo del trabajo fue determinar la factibilidad para la eliminar nitrógeno en aguas residuales domésticas. Un reactor SBR de 5 litros de volumen de trabajo fue investigado con ciclos de diferentes tiempos: 12 h, 8 h y 6 h, a 18 ํ C. La eficiencia del tratamiento del SBR varió en función de la duración del tiempo de ciclo, siendo óptimo el ciclo con la secuencia anóxico/aerobio/anóxico con 6 horas de duración. Debido a la poca concentración de materia orgánica presente en el agua residual doméstica después del tratamiento anaerobio, fue necesario un suministro adicional de carbono externo antes de la segunda etapa anóxica. La adición de metanol fue un punto clave en el proceso de desnitrificación, empleado como un 
modelo para simular el by-pass de parte de la corriente al reactor anaerobio, en las plantas de tratamiento de aguas residuales. Las eficiencias de eliminación obtenidas fueron: 98\% para el NKT, el $84 \%$ de nitrógeno total y el 77\% para la DQO soluble. El reactor mostró viabilidad, por lo que este proceso puede ser aplicado con éxito como post-tratamiento de un reactor anaerobio que trata de aguas residuales domésticas, para la eliminación de nitrógeno.

En el capítulo 3, se investigó el rendimiento de un biorreactor de película fija para la desnitrificación parcial y total del efluente de un AnMBR que trata el agua doméstica. El agua residual después del tratamiento anaerobio, con baja relación $\mathrm{C} / \mathrm{N}$, contiene parte de la DQO no eliminada previamente que no es suficiente para la desnitrificación heterótrofa convencional. Como el efluente del reactor anaerobio de baja temperatura contiene metano y sulfuro disuelto y sobresaturado, se evaluó la viabilidad de utilizar estos compuestos reducidos como dadores de electrones para eliminar $80 \mathrm{mg} \mathrm{N}-\mathrm{NO}_{x}{ }^{-} / \mathrm{L}$ a diferentes tiempos de residencia, obteniendo el óptimo en 2 h. Además, se estudió la influencia de la relación $\mathrm{NO}_{2}{ }^{-} / \mathrm{NO}_{3}{ }^{-}(100 \% / 0 \% ; 50 \% / 50 \%$; $25 \% / 75 \%$ and $0 \% / 100 \%$ ) en la alimentación. Se obtuvieron resultados satisfactorios consiguiendo la eliminación total de nitrógeno en el efluente de desnitrificación, siendo conscientes del caso con $100 \%$ de $\mathrm{NO}_{3}{ }^{-}$en la alimentación, que estaba en el límite del proceso. El metano fue el dador de electrones principal que se utilizó para eliminar los nitritos y nitratos, con más de 70\% de participación.

En el capítulo 4, una planta piloto de desnitritación operó durante más de cinco meses tratando de aguas residuales domésticas con alta concentración de nitrógeno amoniacal procedente del proceso anaerobio, en condiciones de temperatura ambiente $(18 \stackrel{\circ}{ } \mathrm{C})$. El proceso consistía en un biofiltro con $2 \mathrm{~h}$ de tiempo de residencia hidráulico (TRH) para desnitritación. Para estudiar la viabilidad del proceso desnitritación, se suministraron al reactor anóxico distintas concentraciones de nitrito sintético para simular el efluente de un proceso nitritación. Se investigó la desnitritación avanzada de aguas residuales utilizando materia orgánica y dadores de electrones alternativos procedentes de un tratamiento anaerobio: metano y sulfuro. Las bacterias desnitrificantes fueron capaces de tratar el agua con una concentración de entrada de nitrito de $75 \mathrm{mg} \mathrm{N}-\mathrm{NO}_{2}{ }^{-} / \mathrm{L}$ con una eficacia de eliminación del 92.9\%. Cuando la concentración alimentación de nitrito fue más alta, fue necesario recircular el gas obtenido en el reactor anóxico para mejorar la eliminación de nitrito, logrando una eficacia de eliminación de $\mathrm{NO}_{2}{ }^{-}$de $98.3 \%$. 
En el capítulo 5, una planta piloto de desnitrificación/nitrificación fue diseñada, construida y operada para tratar el efluente de un reactor anaerobio. Se examinó el efecto de la recirculación de nitrato y la relación $\mathrm{C} / \mathrm{N}$ en la eliminación de nitrógeno y materia orgánica residual. El sistema consistía en un proceso de tratamiento de dos etapas: anóxica y aerobia. El TRH del sistema fue de $2 \mathrm{~h}$ para el biorreactor anóxico y de $4 \mathrm{~h}$ para el aerobio. El aumento de la recirculación de nitrato no supuso una mejora significativa en la eliminación de nitrógeno debido a la insuficiencia de fuente de carbono. El agua residual a tratar tenía una relación de C/N de 1.1, mostrando falta de carbono orgánico. La adición de metanol fue un punto clave en el proceso de desnitrificación empleado como un modelo simular el by-pass de parte de la corriente en el reactor anaerobio. La máxima eliminación de nitrógeno y materia orgánica (84,7\% y 96\%, respectivamente) se logró con una relación de recirculación de nitrato de 600\% y un $\mathrm{C} / \mathrm{N}$ de 8.25 , ajustado por la adición de metanol.

En el capítulo 6, se ha simulado la viabilidad técnica y económica del tratamiento anaerobio de membrana de aguas residuales y la eliminación nitrógeno. El proceso se simuló usando datos experimentales analizando la influencia de diferentes dadores de electrones (metano, materia orgánica y sulfuro) en la capacidad de eliminación de nitrógeno. Se evaluaron diferentes escenarios cambiando la concentración de los componentes implicados y evaluando su efecto sobre la capacidad de eliminación de nitrógeno, así como la capacidad de producir biogás en el tratamiento anaerobio. Estos escenarios implican por una parte, el incremento de la DQO soluble disponible para la etapa de eliminación de nitrógeno. La alimentación de la DQO en el reactor se ajustó a valores entre $15 \%$ y 30\%, asumiendo diferentes relaciones de mezcla con la corriente de alimentación del reactor anaeróbico. Por otro lado, se bombearon diferentes flujos de biogás procedentes del reactor anaerobio al reactor de desnitritación. El objetivo fue lograr una capacidad de eliminación de nitrógeno tal que se pueda conseguir un efluente con 10-20 mg N/L. A continuación, se estudió en detalle el escenario más prometedor y se comparó con los costes asociados a la EDAR con un tratamiento biológico anaerobio usando un sistema de membranas. Los resultados indicaron que el proceso propuesto es viable ya que los costos fijos y variables de las dos plantas de tratamiento son similares. 
Abbreviations and Symbols 
AnMBR Anaerobic membrane bioreactor

AOB Ammonium oxidizing bacteria

BOD Biological oxygen demand $\left(\mathrm{mg} \mathrm{O}_{2} / \mathrm{L}\right)$

BOE Official Spanish Bulletin

BNR Biological nutrient removal

COD Chemical oxygen demand $\left(\mathrm{mg} \mathrm{O}_{2} / \mathrm{L}\right)$

DO Dissolved oxygen $\left(\mathrm{mg} \mathrm{O}_{2} / \mathrm{L}\right)$

FA Free ammonia

FNA Free nitrous acid

GC Gas chromatography

GHG Greenhouse gases

HPLC high-liquid performance chromatography

HRT Hydraulic retention time (h)

MBR Membrane bioreactor

NLR Nitrogen loading rate $\left(\mathrm{kg} \mathrm{N} / \mathrm{m}^{3} \mathrm{~d}\right)$

NOB Nitrite oxidizing bacteria

OM Organic matter

ORP Oxidation-reduction potential $(\mathrm{mV})$

$Q_{\text {in }} \quad$ Inlet flow

QL Quantification limit

SAF Submerged aerated filters

sCOD Soluble chemical oxygen demand $\left(\mathrm{mg} \mathrm{O}_{2} / \mathrm{L}\right)$

SBR Sequencing batch reactors

SND Simultaneous nitrification/denitrification

SRT Solid retention time (d) 
TKN Total Kjeldahl nitrogen (mg N/L)

TN Total nitrogen

TSS Total suspended solids (mg/L)

UASB Upflow anaerobic sludge blanket

VSS Volatile suspended solids ( $\mathrm{mg} / \mathrm{L}$ )

WWTP Wastewater treatment plant 


\title{
Chapter 1: State of the Art. Nitrogen removal in domestic wastewater after anaerobic treatment
}

\begin{abstract}
A wastewater treatment system has to remove suspended material, dissolved $\mathrm{OM}$, pathogens and dissolved inorganic material. Such treatment systems must fulfill many requirements to be feasibly implemented, such as simple design, use of non-sophisticated equipment, high treatment efficiency, and low operating and capital costs. Conventional nitrification/denitrification and other alternatives are proposed to remove N. Anaerobic processes achieve high OM removal efficiencies without oxygen requirement. Anaerobic membrane technology can produce a solid free effluent, and enables short HRT and high SRT. To obtain an effluent that meets requirements of the environmental legislation regarding $N$ and protects the receiving water bodies, anaerobic membrane bioreactors can play an important role with post-treatment systems based on biofilters and sequencing batch reactors among others. Much progress has been achieved in the last years in terms of understanding the pollutants elimination from wastewater. However, some challenges must still be overcome before a sustainable and efficient domestic wastewater treatment technology is achieved.
\end{abstract}

Keywords: Domestic wastewater - Nitrogen - Organic matter - SBR - Biofilters. 


\section{INTRODUCTION: Water and Wastewater}

The uncontrolled disposal to the environment of domestic, industrial and agricultural liquid, solid and gaseous wastes constitutes one of the most serious threats to the sustainability of the human race because of water sources, land and air contamination and because its potential contribution to global warming ${ }^{[1]}$. The amount and type of waste produced in households is influenced by the behavior, lifestyle and life standard of inhabitants as well as the technical and juridical framework that regulates the disposal standards. In the case of household wastes, the composition of wastewater and solid wastes from households is a result of the distribution of contributions from various sources within the household ${ }^{[2,3]}$. Moreover, every community produces air emissions. In this introduction, the technologies review is focused in the analysis of the wastewater generation and treatment.

The liquid wastewater is basically the water supplied to the community after it has been used in a variety of applications. From the standpoint of generation sources, wastewater may be defined as a combination of the liquid wastes removed from residences, institutions, and commercial and industrial establishments, together with such groundwater, surface water, and stormwater as may be present ${ }^{[4]}$. Increasingly amounts of domestic and industrial sewage are generated due to rapid population growth, expansion of cities and industrial development. These increasing activities make it of ultimate importance to redouble efforts to maintain a clean and safe environment ${ }^{[5,6]}$. In this context, the quality of water is central to all of the roles

that water plays in our lives ${ }^{[7]}$. Water is the source of life on earth, and human civilizations blossomed where there was reliable and clean freshwater. Use of water by humans - for drinking, washing, and recreation - requires water free of biological, chemical, and physical contaminations. Plants, animals, and the habitats that support biological diversity also need clean water to develop themselves. Water of a certain quality is also needed to grow food, power cities and run industries ${ }^{[7]}$.

Wastewaters are discharged into rivers and streams, which could cause deterioration of the environment if the wastewater is not correctly adapted to the receiving source. This activity modifies the nature of the river and receiving bodies, which can provoke several problems, such as eutrophication and pollution. As consequence, big problems for human health as well as for aquatic flora and fauna can be arisen. For these reasons, wastewaters must be treated before they are discharged to the receiving water bodies. "Treatment" is defined as the process of reducing the pollutants into less harmful end products, adapting the wastewater composition to 
a desired one that does not change the natural composition of the receiving bodies. The process may be accomplished by either physical, chemical, or biological means ${ }^{[8,9]}$.

\subsection{DOMESTIC WASTEWATER: definition}

Domestic wastewater, also known as municipal wastewater or sanitary wastewater or simply sewage, is the used water, which has been discharged from the residential, commercial and institutional zones of a city or a town or a community and collected through sewerage system. Sometimes, partially treated liquid wastes form small industries are also collected and discharged into the sanitary sewers and thus included with domestic wastewater ${ }^{[10]}$. Domestic wastewater is the most abundant type of wastewater that falls into the category of lowstrength waste streams, characterized by low organic strength and high particulate organic matter content ${ }^{[11]}$. It is composed of human body wastes (faeces and urine) together with the water used for flushing toilets, and the wastewater resulting from personal washing, laundry, food preparation and the cleaning of kitchen utensils ${ }^{[12]}$.

\subsection{DOMESTIC WASTEWATER: constituents and composition}

Typical domestic wastewater consists of about $99.9 \%$ wt. water and $0.1 \%$ wt. pollutants. About 60 to $80 \%$ of the pollutants are found as dissolved material and the rest are found as suspended matter. The pollutants include mineral and organic matters, suspended solids, oil and grease, detergents, nitrogen, phosphorous, sulfur, phenols, and heavy metals among others. Domestic wastewaters also contain large amounts of bacteria and viruses, some of them pathogenic ${ }^{[1]}$. The constituents in domestic wastewater can be divided into nine main categories, which are displayed in Table 1.

The concentrations found in wastewater result from a combination of pollutant load and the amount of water in which the pollutant is "diluted". The composition of a municipal wastewater varies significantly from one location to another. On a given location the composition will vary with time due to variations in the discharged amounts of substances. The composition of typical domestic wastewater is shown in Table 2 where concentrated wastewater (high) represents cases with low water consumption and/or infiltration. Diluted wastewater (low) represents high water consumption and/or infiltration. 
Table 1. Categories of constituents found in domestic wastewater ${ }^{[2]}$.

\begin{tabular}{|c|c|c|}
\hline Constituents Categories & Actual Constituents & Risks \\
\hline Microorganisms & $\begin{array}{l}\text { Pathogenic bacteria, virus and } \\
\text { worms eggs }\end{array}$ & $\begin{array}{l}\text { Risk when bathing and eating } \\
\text { shellfish }\end{array}$ \\
\hline $\begin{array}{l}\text { Biodegradable organic } \\
\text { materials }\end{array}$ & $\begin{array}{l}\text { Oxygen depletion in rivers, } \\
\text { lakes and fjords }\end{array}$ & Fish death, odors \\
\hline Other organic materials & $\begin{array}{l}\text { Detergents, pesticides, fat, oil } \\
\text { and grease, coloring, solvents, } \\
\text { phenols, cyanide }\end{array}$ & $\begin{array}{l}\text { Toxic effect, aesthetic } \\
\text { inconveniences, bio accumulation } \\
\text { in the food chain }\end{array}$ \\
\hline Nutrients & $\begin{array}{l}\text { Nitrogen, phosphorus, } \\
\text { ammonium }\end{array}$ & $\begin{array}{l}\text { Eutrophication, oxygen depletion, } \\
\text { toxic effect }\end{array}$ \\
\hline Metals & $\mathrm{Hg}, \mathrm{Pb}, \mathrm{Cd}, \mathrm{Cr}, \mathrm{Cy}, \mathrm{Ni}$ & Toxic effect, bioaccumulation \\
\hline $\begin{array}{l}\text { Other inorganic } \\
\text { materials }\end{array}$ & $\begin{array}{l}\text { Acids, for example hydrogen } \\
\text { sulfide, bases }\end{array}$ & Corrosion, toxic effect \\
\hline Thermal effects & Hot water & $\begin{array}{l}\text { Changing living conditions for } \\
\text { flora and fauna }\end{array}$ \\
\hline Odor (and taste) & Hydrogen sulfide & $\begin{array}{l}\text { Aesthetic inconveniences, toxic } \\
\text { effect }\end{array}$ \\
\hline Radioactivity & & Toxic effect, accumulation \\
\hline
\end{tabular}

Table 2. Typical composition of raw domestic wastewater $(\mathrm{ppm})^{[2]}$. COD: Chemical Oxygen Demand. BOD: Biological Oxygen Demand. VFA: Volatile Fatty Acids. N Total: Total Nitrogen. Ammonia-N: Nitrogen as ammonia. P total: Total phosphorus. Ortho-P: phosphorous as phosphate. TSS: Total Suspended Solids. VSS: Volatiles Suspended Solids.

\begin{tabular}{lccc} 
Parameter & $\begin{array}{c}\text { High } \\
\text { concentration }\end{array}$ & $\begin{array}{c}\text { Medium } \\
\text { concentration }\end{array}$ & $\begin{array}{c}\text { Low } \\
\text { concentration }\end{array}$ \\
\hline COD total & 1200 & 750 & 500 \\
\hline COD soluble & 480 & 300 & 200 \\
\hline COD suspended & 720 & 450 & 300 \\
\hline BOD & 560 & 350 & 230 \\
\hline VFA (as acetate) & 80 & 30 & 10 \\
\hline N total & 100 & 60 & 30 \\
\hline Ammonia-N & 75 & 45 & 20 \\
\hline P total & 25 & 15 & 6 \\
\hline Ortho-P & 15 & 10 & 4 \\
\hline TSS & 600 & 400 & 250 \\
VSS & 480 & 320 & 200
\end{tabular}


The organic matter is the major pollutant in domestic wastewater ${ }^{[2]}$. The amount of organic matter in domestic wastes determines the degree of biological treatment required ${ }^{[13]}$. Some studies have reported that the organic matter in domestic wastewaters is composed mainly of proteins, lipids and carbohydrates. ${ }^{[12,14,15]}$. Since most of the nutrients are normally soluble, they cannot be removed by settling, filtration, flotation or other means of solid-liquid separation $^{[2]}$.

\section{WASTEWATER TREATMENT}

There is an increasing need to develop reliable technologies for the treatment of domestic wastewater to protect both public health and those of the receiving bodies or users. Treatment generally means the partial reduction or complete elimination of the impurities present in the wastewater so that their concentration reaches an acceptable level for its final disposal or proper reuse. Defining the level of wastewater treatment and selecting the treatment processes depends mainly on the effluent quality standards prescribed by the Law. A treatment system has to remove suspended material, dissolved organic material, pathogens and, sometimes, dissolved inorganic material. Such treatment systems must fulfill many requirements to be feasibly implemented, such as simple design, use of non-sophisticated equipment, high treatment efficiency, and low operating and capital costs ${ }^{[1,10,16,17]}$.

As outlined in Figure 1, a conventional treatment plant consists of a train of individual unit processes set in a series, with the effluent of one process becoming the influent of the next inline process. The sewage treatment processes can be classified in four groups: preliminary treatment, primary treatment, secondary treatment and tertiary treatment. Many treatment processes also generate sludge as by-product and there are several alternatives for sludge treatment ${ }^{[1,16]}$.

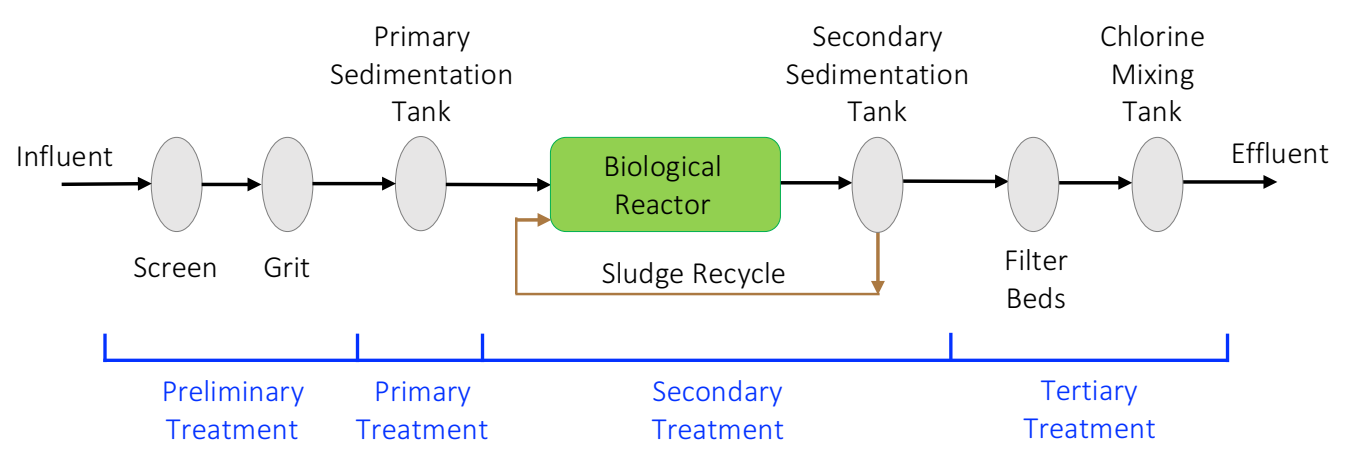

Figure 1: Process diagram of a conventional sewage treatment plant. 
A general treatment scheme includes a preliminary treatment (e.g. screens and grit chambers) that removes most of the coarse and heavy inorganic (typically garbage and grit) and organic solids (coarse food particles). A large fraction of total suspended solids and a fair proportion of the organic matter in suspended solids can be removed by gravity in a primary sedimentation tank. Preliminary and primary treatments are based on physical processes. The secondary treatment is based on biological processes. Biological reactors are employed to remove the biodegradable organics. Tertiary treatment is usually based on physicochemical processes. Polishing to remove fine particles and disinfection are typically carried out in filtration and chlorination or UV disinfection reactor respectively ${ }^{[16]}$. Wastewater treatment plants (WWTPS) have been evolved over the time to adapt to the growth of cities, the environmental changes (including climate change), the economic conditions and, finally, the requirements of society under the influence of both environment and economy ${ }^{[18,19]}$.

Suspended solids are the most visible of all impurities in wastewater and may be either organic or inorganic in nature. It is therefore not surprising that the first wastewater treatment systems, introduced by the end of the $19^{\text {th }}$ century, were designed as units for the separation of solids from liquids by means of gravity settling: a process known as the primary treatment of wastewater. When the first efficient and reliable treatment units entered into operation, it soon became clear that these could treat wastewaters only partially for a simple reason: a large fraction of the organic material in wastewater is not settleable and therefore is not removed by primary treatment. With the objective of improving the treatment efficiency of wastewater treatment plants, secondary treatment was devised in the early years of the $20^{\text {th }}$ century, and now forms the basis of wastewater treatment worldwide. Secondary treatment is characterized by the use of biological methods to remove the organic material present in the wastewater ${ }^{[20,}$ 21]. With appropriate analysis and environmental control, almost all wastewaters containing biodegradable constituents with a BOD/COD ratio of 0.5 or greater can be treated easily by biological means. In comparison to other methods of wastewater treatment, it also has the advantages of lowering treatment costs with no secondary pollution ${ }^{[22]}$.

Both, aerobic and anaerobic, processes can be used as biological treatments to the wastewater streams. Aerobic processes involve the use of free or dissolved oxygen by microorganisms (aerobes) in the conversion of organic wastes to biomass and $\mathrm{CO}_{2}$. In anaerobic processes, complex organic wastes are degraded into methane, $\mathrm{CO}_{2}$ and $\mathrm{H}_{2} \mathrm{O}$ through four basic steps (hydrolysis, acidogenesis, acetogenesis and methanogenesis) in the absence of oxygen. Aerobic biological processes are commonly used in the treatment of organic wastewaters for 
achieving high degree of treatment efficiency. On the other hand, considerable progress has been achieved in anaerobic biotechnology for waste treatment based on the concept of resource recovery and utilization while still achieving the objective of pollution control ${ }^{[22]}$.

Spain, as a member of the European Union, is obliged to comply with the Community rules. Council Directive 91/271/EEC of 21 May 1991, established the minimum requirements for the collection, treatment and disposal of domestic wastewater. This Directive was transposed into Spanish law by Royal Decree Law 11/1995, committed to achieve good ecological status of waters for 2015 set out in the Water Framework Directive (Directive 2000/60/EC of the European Parliament and the Council of 23 October 2000, establishing a Community framework action in the field of water policy) ${ }^{[23]}$.

Initially, the goal of WWTPs was to simply release the water of the drains from the pollutants before discharging it back to the environment. As a result, the WWTPs were designed on the principle of the activated sludge process. Aeration of municipal sewage resulted in an increased removal rate of organic material, while at the same time the formation of macroscopic flocs was observed, which could be separated from the liquid phase by settling, forming a biological sludge. The addition of this sludge to a new batch of wastewater tremendously accelerate the removal rate of the organic material. The sludge bacteria, together with some protozoa and other microbes, are collectively referred to as activated sludge. The concept of treatment is very simple. The bacteria remove small organic carbon molecules by 'eating' them. As a result, the bacteria grow, and the wastewater is cleansed. The activated sludge process is energy consuming and does not take into account the potential of energy and nutrient recovery ${ }^{[18,20,}$ ${ }^{21]}$. Conventional activated sludge requires high electrical power consumption for pumping and aeration. The excess of sludge generated in this system is a secondary solid waste, and its disposal is a major environmental concern ${ }^{[19,24]}$. Furthermore, this technology is inefficient in eliminating contaminants, resulting thus in their dissemination into the environment. Advanced effluent treatment has also severe limitations depending on the type of treatment and compound to be removed. All of them can only remove certain compounds completely. Some compounds are removed only partially and others are not removed at all ${ }^{[25]}$.

The technological achievements in the fields of monitoring and controlling the design of stable and efficient processes (both physicochemical and biological) together with the development of suitable benchmarking and economic tools have begun to change the philosophy of WWTPs from treatment to valorization facilities. This means that sewage 
treatment should be incorporated into a more holistic management scheme, which aims at reducing the pollutants as well as enhancing nutrient, water and energy recycling in order to maintain the environment's integrity in an economic feasible but also efficient way ${ }^{[18]}$.

The presence of mineral compounds in the effluent, especially the nutrients nitrogen and phosphorus, could cause a serious disruption of the ecological equilibrium in the receiving water ${ }^{[20]}$. Some of the problems of excessive nutrients in water bodies include reduced oxygen concentration in water, which can lead to fish death, eutrophication, and over-fertilization ${ }^{[26]}$. Eutrophication reduces water quality, alters the ecological structure and function of freshwater, and poses many potential hazards to human and animal health ${ }^{[27]}$. The increasing public concern for environmental protection has led to stricter nutrient discharge standards in domestic wastewater ${ }^{[28]}$. As consequence, to protect the water quality in the receiving water bodies, most of the efforts have been focused on the development of new technologies in which, in addition to the removal of suspended solids and organic material, also the nutrients nitrogen and phosphorus were eliminated ${ }^{[20,28]}$. A variety of physicochemical, chemical, and biological methods have been used to remove nutrients from wastewater ${ }^{[26]}$. However, biological nitrogen removal is preferred over physicochemical processes because it is capable of removing fixed nitrogenous compounds to harmless dinitrogen gas $\left(\mathrm{N}_{2}\right)$ in a more effective and economical way ${ }^{[27]}$.

In the next three sections, the biological process of nitrogen elimination is reviewed. Section 2.1 in this chapter reviews the mechanisms of nitrogen elimination from wastewater. Section 2.2 reviews the Sequential Batch Reactor Technology and finally, section 2.3 reviews the developed technologies of anaerobic biological treatments for nitrogen and organic matter removal from wastewater as a secondary treatment in a WWTP.

\subsection{NITROGEN REMOVAL FROM WASTEWATER: Biological mechanisms}

Nitrogen is essential for life, as it is the fourth most abundant element in the biosphere. The $\mathrm{N}$ cycle in the biosphere is governed by various catabolic processes, anabolic processes and ammonification. These processes have been engineered over the years and applied in WWTPS to implement biological $\mathrm{N}$ removal to produce effluents with a lower environmental impact ${ }^{[28]}$.

\subsubsection{Conventional Nitrification/Denitrification.}

In the 1950s, additional to the organic material removal, nitrification was introduced in the activated sludge process ${ }^{[20]}$. Conventional $\mathrm{N}$ removal comprises two completely different 
microbial processes: nitrification and denitrification ${ }^{[29]}$.

Nitrification is a two-step biological oxidation of ammonium, using oxygen ${ }^{[20]}$. The first step, nitritation (Eq. [1]), is the oxidation of ammonium to nitrite $\left(\mathrm{NO}_{2}{ }^{-}\right)$. The $\mathrm{NH}_{4}{ }^{+}$serves as $\mathrm{N}$ source for the synthesis of new biomass and as the sole energy source for the growth of ammoniumoxidizing bacteria (AOB).

Nitritation: $\quad \mathrm{NH}_{4}^{+}+2 \mathrm{HCO}_{3}{ }^{-}+1.5 \mathrm{O}_{2} \rightarrow \mathrm{NO}_{2}{ }^{-}+2 \mathrm{CO}_{2}+3 \mathrm{H}_{2} \mathrm{O}$

The second step, nitratation (Eq. [2]), is the oxidation of nitrite to produce nitrate $\left(\mathrm{NO}_{3}{ }^{-}\right)$by nitrite-oxidizing bacteria ${ }^{[30]}$.

Nitratation: $\quad \mathrm{NO}_{2}^{-}+1.5 \mathrm{O}_{2} \rightarrow \mathrm{NO}_{3}^{-}$

The complete oxidation of $\mathrm{NH}_{4}{ }^{+}$to $\mathrm{NO}_{3}{ }^{-}$by $\mathrm{AOB}$ and $\mathrm{NOB}$ is overall called nitrification ${ }^{[20,28]}$. Both functional groups of nitrifiers are aerobic and chemolithoautotrophic ${ }^{[29]}$.

Denitrification is the reduction of nitrate (Eq. [3]) to nitrogen gas. It is a sequential process that consists of the following reduction steps: $\mathrm{NO}_{3}{ }^{-}$to $\mathrm{NO}_{2}{ }^{-}$, nitric oxide (NO), nitrous oxide $\left(\mathrm{N}_{2} \mathrm{O}\right)$, and $\mathrm{N}_{2}$. Biological denitrification is carried out entirely by heterotrophic bacteria, which requires a biodegradable organic carbon source as an electron donor to complete the reduction process ${ }^{[28]}$. Denitrification only develops in an anoxic environment, which is characterized by the presence of nitrate or nitrite and the absence of dissolved oxygen.

Heterotrophic denitrification over nitrate:

$$
\mathrm{NO}_{3}{ }^{-}+1.08 \mathrm{CH}_{3} \mathrm{OH}+0.24 \mathrm{H}_{2} \mathrm{CO}_{3} \rightarrow 0.056 \mathrm{C}_{5} \mathrm{H}_{7} \mathrm{O}_{2} \mathrm{~N}+0.47 \mathrm{~N}_{2}+\mathrm{HCO}_{3}{ }^{-}+1.68 \mathrm{H}_{2} \mathrm{O}
$$

As the nitrifying process is extremely slow compared to denitrification, two separate reactors to accommodate different sets of conditions are required.

In the first units constructed for biological nitrogen removal, the nitrified effluent from an activated sludge process was discharged in a second reactor, operated without aeration. In this second reactor, the demand of organic carbon was often not satisfied because of the high $\mathrm{N}$ load and relative low carbon content of the wastewater. To increase the denitrification rates under such conditions, usually readily biodegradable organic compounds like methanol and acetate was added to the second reactor ${ }^{[20,29]}$. Thus, the treatment system was composed of two reactors with different sludge, the first one being for organic material removal and 
nitrification; and the second one, for denitrification. However, it was established soon that the organic material present in the wastewater could be very well used for nitrate reduction ${ }^{[20,29]}$.

The modified designs placed the denitrification tank before the aerobic stage. Therefore, the classic bioreactor configuration to perform nitrification-denitrification consisted of an anoxic tank followed in used by an aerobic tank and the secondary settler. In this process, known as $\mathrm{A} / \mathrm{O}$, the denitrification tank directly receives the wastewater containing relatively high amounts of carbon sources, and external organic material is not needed. Two recirculation flows are traditionally used: (1) internal recirculation from the aerobic compartment to the anoxic tank to supply electron acceptors for denitrification $\left(\mathrm{NO}_{2}{ }^{-}\right.$and $\left.\mathrm{NO}_{3}{ }^{-}\right)$and (2) external recirculation from the secondary settler to the biological process inflow to maintain a target biomass retention time (normally higher than 7 days) and a proper sludge concentration. These processes have unaerated zones for denitrification and aerated zones where nitrification takes place together with organic material removal. An important issue is the aeration, which must be adjusted to provide enough dissolved oxygen (DO) for nitrification (3.16 $\mathrm{g} \mathrm{O}_{2} \mathrm{~g}^{-1} \mathrm{NH}_{4}^{+}$) but avoiding unnecessary energy consumption. The aeration requirements represent one of the main fractions of the treatment cost in WWTPs performing conventional nitrification/denitrification $[20,28,29]$. In WWTP it is common to include an anaerobic tank before the anoxic/oxic stages. This process $\mathrm{A}^{2} / \mathrm{O}$ with separate anaerobic, anoxic, and aerobic tanks is a suitable method for biological nitrogen removal (schema shown in Figure 2). Denitrification of the $\mathrm{NO}_{3}{ }^{-}$recirculated from a downstream aerobic tank occurs in an anoxic tank where denitrifiers can utilize the organic matter present in the influent, avoiding the need for an additional organic carbon source. However, the $\mathrm{A}^{2} / \mathrm{O}$ configuration normally requires a high mixed liquid return ratio (2$4 \mathrm{Q}_{\text {in }}$ ) from the aerobic zone to the anoxic zone to bring more $\mathrm{NO}_{3}{ }^{-}$back for denitrification. High return ratios can result in a DO concentration increase and COD dilution in the anoxic zone. This inevitably deteriorates the denitrification efficiency, especially when the organic matter present in the influent wastewater is insufficient to deplete the DO present in the recycled mixed liquor. In addition, high return ratios also lead to higher energy consumption and increased operating costs ${ }^{[27]}$.

The denitrification potential of wastewater is primarily a function of the available organic carbon, usually expressed as chemical oxygen demand (COD)/nitrogen(N) or carbon/nitrogen $(C / N)^{[27]}$. One of the main factors limiting the nitrogen removal efficiency in municipal WWTPs is the $\mathrm{C} / \mathrm{N}$ ratio. Typical values in domestic wastewater range between 10.5 and 12.5 and are sufficient to complete the denitrification of total N (TN) of the influent wastewater. However, 
the sludge digestion recirculation to the inflow of the plant or the reception of N-rich external inputs may increase the $\mathrm{N}$ load of the WWTP. This means actual lower $\mathrm{C} / \mathrm{N}$ ratios that fail to meet the discharge quality standards ${ }^{[28]}$. One way to get satisfactory nitrogen removal performance for wastewater with a $\mathrm{C} / \mathrm{N}$ ratio lower than the critical value is to introduce an innovative nitrogen removal pathway, or treatment processes, which can support nitrogen removal with low or zero organic carbon demand. These pathways are presented below. An alternative way is to add external carbon for denitrification ${ }^{[27]}$.

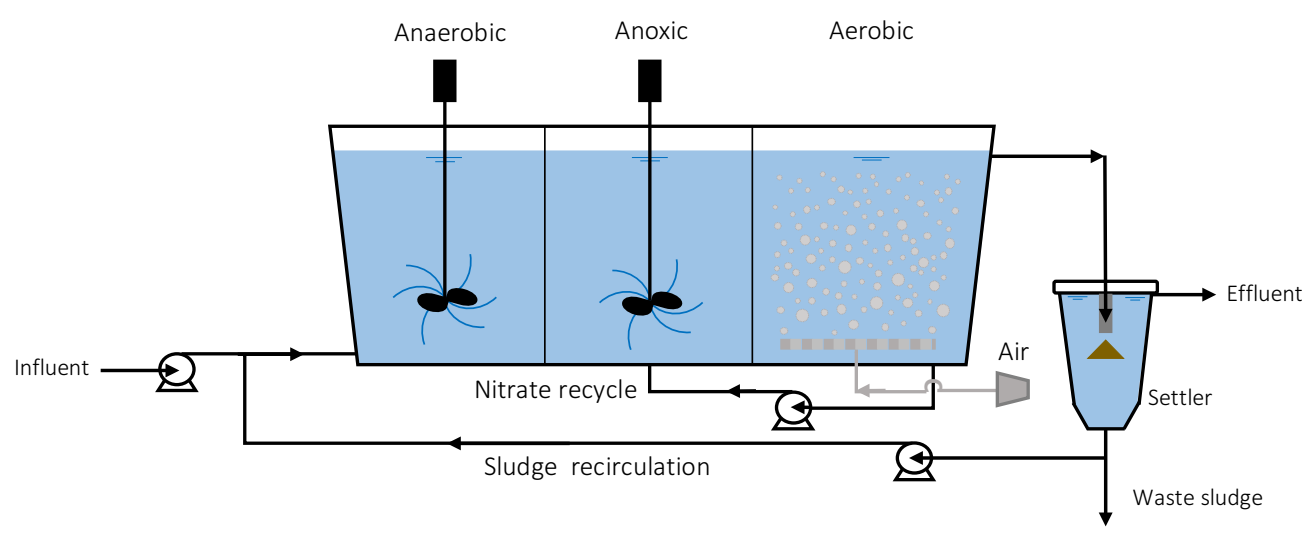

Figure 2: Schematic diagram of the anaerobic/anoxic/oxic $\left(\mathrm{A}^{2} / \mathrm{O}\right)$ process.

\subsubsection{Simultaneous Nitrification/Denitrification}

As seen before, the nitrification and denitrification processes are usually carried out separately in aerobic and anoxic compartments, respectively. However, as it has been reported, some heterotrophic nitrifiers could denitrify nitrite and nitrate aerobically. Nitrification and denitrification take place concurrently in a single reactor under aerobic conditions. This is often referred as Simultaneous Nitrification/Denitrification (SND) process. Generally, SND occurs naturally inside microbial biofilms and flocs due to the dissolved oxygen (DO) gradient established across the biomass. The biodegradable organic matter availability in the deep biofilm regions, the DO concentration gradients and the floc size are the three main parameters affecting SND performance. In this sense, a limited DO level in the bulk liquid (0.5-1.5 g- $\mathrm{O}_{2} \mathrm{~m}^{-3}$ ) favors the presence of SND in aerobic tanks. The optimal C/N ratio for SND was calculated at 11.1, where the nitrification and denitrification reactions are balanced ${ }^{[28,31]}$.

SND is more cost effective than the conventional process because the C-source consumption is $22-40 \%$ lower and the sludge yield is reduced by $30 \%$. Due to the low DO level set point used, the aeration intensity is also reduced. SND is performed in a single reactor, which represents a smaller footprint, and could be a good solution to upgrade WWTP without expanding the 
existing facilities. It could be also considered an option to treat domestic wastewater with relatively low $\mathrm{C} / \mathrm{N}$ and/or inorganic $\mathrm{C}$ limitation for autotrophic nitrifiers ${ }^{[28,32,33]}$.

\subsection{3. $\mathrm{N}$ removal over $\mathrm{NO}_{2}^{-}$.}

Nitrite $\left(\mathrm{NO}_{2}{ }^{-}\right)$is an intermediate in both, nitrification and denitrification pathways. In the combined nitrification/denitrification process, $\mathrm{NH}_{4}{ }^{+}$is oxidized to $\mathrm{NO}_{2}{ }^{-}$and then to $\mathrm{NO}_{3}{ }^{-}$, which is again converted to $\mathrm{NO}_{2}{ }^{-}$before $\mathrm{N}_{2}$ gas formation. Therefore, the production of $\mathrm{NO}_{3}{ }^{-}$is not required to complete the whole $\mathrm{N}$-removal process ${ }^{[28]}$. The partial nitrification pathway may be formed by controlling the $\mathrm{NH}_{4}{ }^{+}$oxidation to $\mathrm{NO}_{2}{ }^{-}$(nitritation) instead of to $\mathrm{NO}_{3}{ }^{-}$(nitratation) and the coupled by reduction of the accumulated $\mathrm{NO}_{2}{ }^{-}$via denitrification ${ }^{[27]}$.

As can be seen in Equations [4] and [5], the application of the shortcut nitrification followed by denitrification of $\mathrm{NO}_{2}{ }^{-}$instead of complete nitrification/denitrification can reduce the treatment costs due to $25 \%$ less aeration and $40 \%$ less biodegradable COD consumption. Therefore, the process becomes highly cost effective for the treatment of wastewater with low $\mathrm{C} / \mathrm{N}$ ratio, as part of the methanol addition can be saved. Moreover, it is known that denitrification rates for $\mathrm{NO}_{2}^{-}$are 1.5-2 times faster than $\mathrm{NO}_{3}{ }^{-}$denitrification rates, allowing higher removal capacities. Moreover, sludge production is reduced by $40 \%$ in shortcut nitrification/denitrification ${ }^{[27,28,34,35]}$.

$\mathrm{NH}_{4}^{+}$removal via $\mathrm{NO}_{3}^{-}$(nitrification/denitrification)

$$
\mathrm{NH}_{4}{ }^{+}+2 \mathrm{O}_{2}+4 \mathrm{~g} \mathrm{COD} \rightarrow 0.5 \mathrm{~N}_{2}+\mathrm{H}_{2} \mathrm{O}+\mathrm{H}^{+}+1.5 \text { g biomass }
$$

Shortcut nitrification/denitrification (nitritation/denitritation):

$$
\mathrm{NH}_{4}^{+}+1.5 \mathrm{O}_{2}+2.4 \mathrm{~g} \mathrm{COD} \rightarrow 0.5 \mathrm{~N}_{2}+\mathrm{H}_{2} \mathrm{O}+\mathrm{H}^{+}+0.9 \text { g biomass }
$$

Unfortunately, $\mathrm{NO}_{2}-\mathrm{N}$ accumulation is difficult to attain. The key factor is to limit as much as possible the oxidation of $\mathrm{NO}_{2}{ }^{-}$to $\mathrm{NO}_{3}{ }^{-}$. Although $\mathrm{NOB}$ generally have higher substrate utilization rates than $A O B$, a forced biological conversion through the $\mathrm{NO}_{2}{ }^{-}$route has been successfully obtained by different approaches. This is always based on the different physiological characteristics of $A O B$ and $N O B$ and their responses to three environmental factors: the temperature, the DO, and the concentration of free ammonia (FA) and free nitrous acid (FNA). These factors can vary significantly and unpredictably in wastewater and treatment processes, so it is difficult to achieve and maintain high removal via nitrite $[27,28,36]$.

\subsubsection{The Anammox process.}


The classical $N$ removal pathway via nitrification and denitrification is costly, because the nitrification stage must be aerated and, if needed, organic carbon sources must be added to maintain denitrification. Therefore, current interest focuses on pathways to $\mathrm{N}$ elimination that require less aeration and external carbon supply. In this context, the anaerobic ammonium oxidizers (Anammox) are highly relevant. These autotrophic bacteria can oxidize $\mathrm{NH}_{4}{ }^{+}$and $\mathrm{NO}_{2}{ }^{-}$ as electron acceptor to produce $\mathrm{N}_{2}$ and a small part of $\mathrm{NO}_{3}{ }^{-}$under anoxic conditions without the requirement of an organic carbon source (Eq. [6]). Thus, this anaerobic process constitutes a 'shortcut' in the $\mathrm{N}$ cycle. Future full-scale implementations of the Anammox process could markedly reduce the space requirements and costs of $\mathrm{N}$ removal from wastewater ${ }^{[27,29]}$.

\section{Anaerobic ammonium oxidation}

$\mathrm{NH}_{4}{ }^{+}+1.32 \mathrm{NO}_{2}{ }^{-}+0.066 \mathrm{HCO}_{3}{ }^{-}+0.13 \mathrm{H}^{+} \rightarrow 1.02 \mathrm{~N}_{2}+0.26 \mathrm{NO}_{3}{ }^{-}+0.066 \mathrm{CH}_{2} \mathrm{O}_{0.5} \mathrm{~N}_{0.15}+2.03 \mathrm{H}_{2} \mathrm{O}$

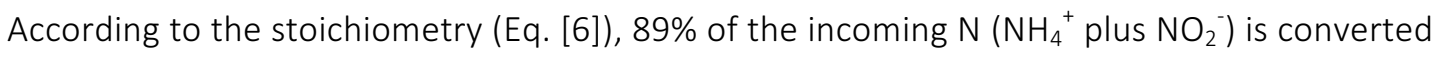
to $\mathrm{N}_{2}$ gas, while the rest (11\%) corresponds to $\mathrm{NO}_{3}{ }^{-}$production. From the environmental engineering point of view, this $\mathrm{NO}_{3}$ produced is considered as a waste of the Anammox process and must be treated further. The anaerobic ammonium oxidation reaction requires a $\mathrm{NO}_{2}{ }^{-}$ supply. Therefore, the process needs to be coupled to a partial nitrification process, in order to aerobically oxidize $60 \%$ of the $\mathrm{NH}_{4}{ }^{+}$of the wastewater to $\mathrm{NO}_{2}{ }^{-}$. Compared to the conventional biological nitrogen removal, the Anammox process presents several advantages such as: 63\% less oxygen demand and $100 \%$ savings on an external $\mathrm{C}$ source for denitrification, because it is a low-oxygen consuming process ${ }^{[27,28,37]}$. Moreover, the Anammox process has the interesting characteristics of very low production of sludge, and very low $\mathrm{CO}_{2}, \mathrm{~N}_{2} \mathrm{O}$, and $\mathrm{NO}$ emissions. For all these reasons, the Anammox process as a cost-effective and energy-saving biotechnology has a great potential in the treatment of $\mathrm{NH}_{4}{ }^{+}$-rich wastewaters with very low $\mathrm{C} / \mathrm{N}$ ratio, such as sludge treatment effluents ${ }^{[27,28,38]}$.

The main handicap to implement this process is the slow growth rate of anaerobic ammonium-oxidizing bacteria. Long start-up periods are required even when working at high temperatures, limiting its application ${ }^{[28,38]}$. In addition, several environmental factors can perturb the Anammox process and affect the N-removal efficiency. The optimum temperature for a maximum growth rate of anaerobic ammonium-oxidizing bacteria was set at 35-37 으, but recent works have obtained high $\mathrm{N}$-removal efficiencies in reactors operated at low temperatures $(<20 \stackrel{\circ}{ })^{[28]}$. Currently, the Anammox process is still confined to a few types of wastewaters (sludge digestate and animal wastewaters) ${ }^{[38]}$. 


\subsubsection{Alternative treatment processes or reactors.}

Common biological nitrogen removal processes occur in various treatments train configurations in WWTPs, including the A/O process and the $\mathrm{A}^{2} / \mathrm{O}$ process. All these processes rely on a predenitrification zone where a portion of the nitrified wastewater is recycled and mixed with the influent to serve as an electron donor for denitrification. Disadvantages include the need for high recirculation rates and the addition of external carbon substrate when the influent $\mathrm{C} / \mathrm{N}$ ratio is not high enough. To overcome this situation, advanced process control methods, new biological treatment processes and reactors such as the modified $\mathrm{A}^{2} / O$ process, the multistage A/O step-feed process have been developed ${ }^{[27]}$.

\subsubsection{Modified $A^{2} / O$ process.}

The modified $\mathrm{A}^{2} / \mathrm{O}$ process avoids the above disadvantages (Figure 3 ). In the modified $\mathrm{A}^{2} / \mathrm{O}$ process $^{[27]}$ :

1. The recycle sludge is directed to a separate preanoxic basin where hydrolysis processes can release biodegradable organic carbon. This carbon can be used in the denitrification processes taking place downstream.

2. The influent wastewater goes directly to the anaerobic zone of the reactor and gets mixed with the wastewater from the pre-anoxic tank. Part of mixed wastewater in this reactor is recirculated to the postanoxic zone at a ratio of $0.4 \mathrm{Q}_{\text {in }}$ to provide available organic carbon for denitrification.

3. In the first aerobic zone, $\mathrm{NH}_{4}{ }^{+}$is oxidized to $\mathrm{NO}_{2}{ }^{-}$and $\mathrm{NO}_{3}{ }^{-}$, and both are fed continuously to the so-called postanoxic zone for denitrification.

4. The treated wastewater passes through a final aerobic tank to minimize the amount of COD in the effluent, and enhances the settling ability of the sludge by minimizing denitrification in the secondary settler. Pilot-scale results showed more than $88 \%$ COD and $70 \%$ TN was removed. 


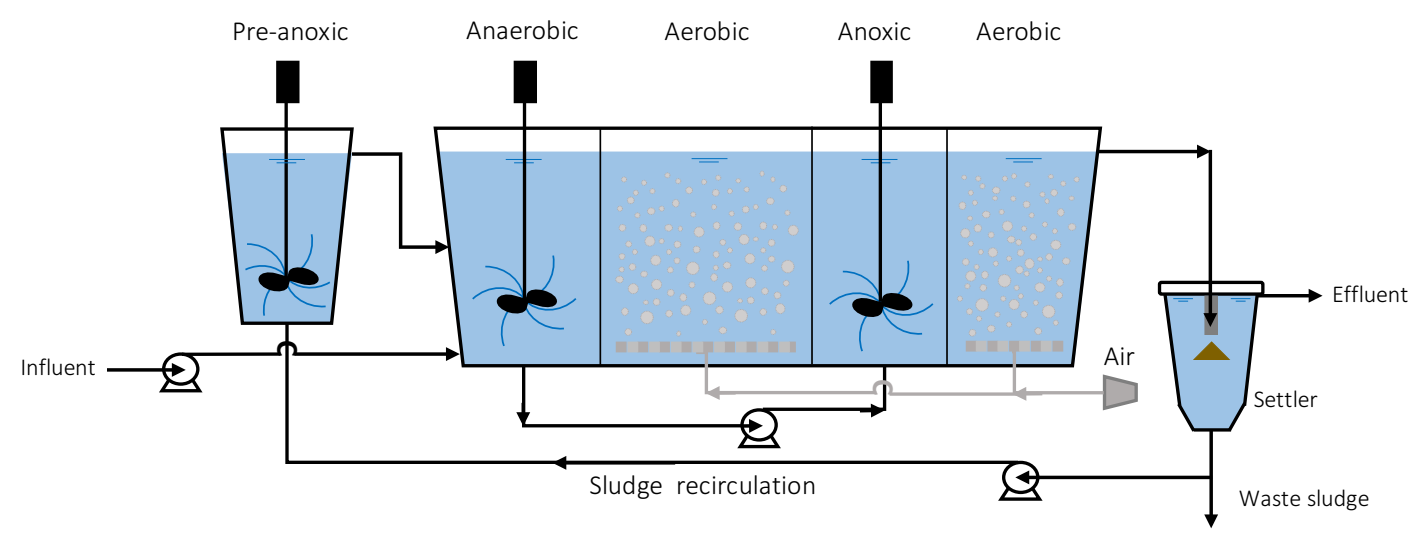

Figure 3: Schematic diagram of the modified $\mathrm{A}^{2} / \mathrm{O}$ process.

\subsubsection{Step-feed multistage A/O process.}

The step-feed multistage A/O process consists of two or more denitrification-nitrification units in series with wastewater distributed at several reactor points so that an internal $\mathrm{NO}_{3}{ }^{-}$ recirculation is unnecessary. A schema of step-feed multistage A/O process is shown in Figure 4. The biodegradable organic material in the influent is utilized for denitrification, and also simultaneous nitrification/denitrification may occur in this process ${ }^{[27]}$.

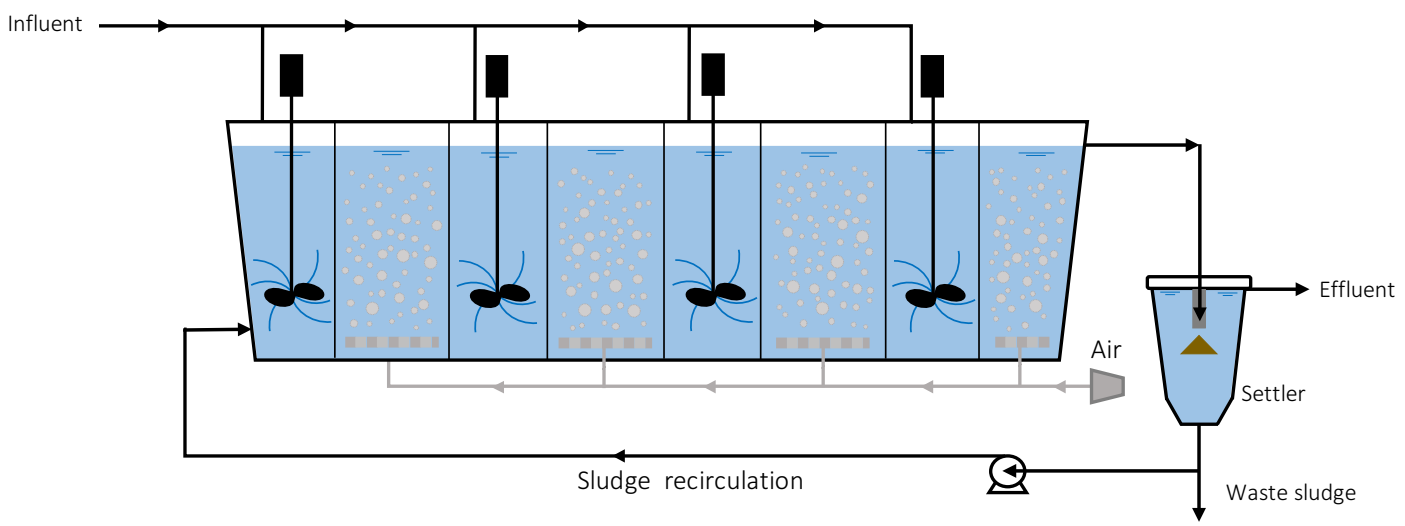

Figure 4: Schematic diagram of the step-feeding multistage anaerobic/oxic $(A / O)$ process.

\subsection{ORGANIC MATTER REMOVAL FROM WASTEWATER: Anaerobic biological treatment.}

The anaerobic process operates in absence of molecular oxygen in the reactor for the growth of microbes and normally fails in the presence of excessive oxygen. Removal of organic content in wastewater is carried out by anaerobic and facultative microorganisms by stabilizing the organic matter into liquid, gases (mainly methane and carbon dioxide) and other stable end products in the absence of oxygen ${ }^{[10]}$. 
Though the process was primarily developed for stabilization and volume reduction of wastewater sludge, it was later on employed for the treatment of industrial wastewater containing high organic wastes ${ }^{[10]}$. Anaerobic treatment of wastewaters is nowadays widely accepted as a probed technology and extensively used ${ }^{[39]}$. Compared to the most conventional aerobic process, anaerobic process should be considered for domestic wastewater treatment as an alternative because of a variety of reasons. Anaerobic treatment can be carried out with technically simple setups, at any scale, and at almost any place. It produces a small amount of excess, well stabilized sludge, and energy can be recovered in the form of biogas ${ }^{[17,40]}$. The sludge quantities produced in the anaerobic process are much smaller that the sludge quantity formed while decomposing the same amount of organic matter under an aerobic pathway. Only about $5-15 \%$ of the organic carbon is converted to biomass during anaerobic decomposition of organic matter, while in aerobic decomposition, the equivalent number is about $50-60 \%{ }^{[1]}$. In addition to the energy that can be recovered from methane-rich biogas, the application of anaerobic processes distinctly reduces the overall energy demand for municipal wastewater treatment because no aeration energy is required for mineralizing the organics ${ }^{[11]}$. Complete anaerobic treatment of domestic wastewater has the potential to achieve net energy production while meeting stringent effluent COD standards ${ }^{[37]}$. Anaerobic treatment of domestic wastewater is receiving increased attention because of the recognized potential for net energy recovery and low sludge production when compared with traditional aerobic processes $^{[41]}$.

Both aerobic and anaerobic systems are capable of achieving high organic removal efficiency. In general, aerobic systems are suitable for the treatment of low strength wastewaters (biodegradable COD concentrations less than $1000 \mathrm{mg} / \mathrm{L}$ ) while anaerobic systems are suitable for the treatment of high strength wastewaters (biodegradable COD concentrations over $4000 \mathrm{mg} / \mathrm{L}$ ). Anaerobic processes achieve organic removal in the range $40-85 \%$ depending on the type of reactor used. The advantages of anaerobic treatment outweigh the advantages of aerobic treatment when treating influents with high concentrations. In addition, anaerobic treatment generally requires less energy with potential bioenergy and nutrient recovery. However, compared to anaerobic systems, aerobic systems achieve higher removal of soluble biodegradable organic matter material and the produced biomass is generally well flocculated, resulting in lower effluent suspended solids concentration. As a result, the effluent quality from an aerobic system is generally higher than the anaerobic system ${ }^{[1,22]}$.

Among the drawbacks in the use of anaerobic reactor for domestic wastewater are found: 
- Temperature: anaerobic wastewater treatment becomes increasingly difficult as temperatures drop below 20 o ${ }^{[42]}$. These difficulties can be attributed to changes in the physico-chemical nature of the wastewater and sludge and the slowing of biochemical reactions. Both have consequences for the microbiological processes in the different trophic levels of anaerobic digestion: hydrolysis, acid- and acetogenesis and methanogenesis.

- Regarding nutrients, the effluent quality do not meet the requirement for wastewater effluent to surface receivers ${ }^{[43,44]}$.

- Biomass: their slow growth rates could create challenges in treating wastewater, especially in start-up periods, due to washout of these slow growing microorganisms ${ }^{[45,}$ 46].

\subsubsection{Upflow anaerobic sludge blanket (UASB).}

There is a large variety of types of anaerobic reactors for treatment of wastewater including: anaerobic digesters of excess sludge, septic tanks, anaerobic lagoons, rotating bed reactor, expanded bed reactor, fluidized bed reactor, upflow anaerobic sludge blanket (UASB), expanded bed granular reactor ${ }^{[1]}$. One of the most employed technologies is the UASB that has successfully been used to treat a variety of wastewaters ${ }^{[39]}$.

The success of the UASB reactor relies on the establishment of a dense sludge bed in the bottom of the reactor where all biological processes take place. This sludge bed is basically formed by accumulation of incoming suspended solids and bacterial growth. Under certain conditions, bacteria can naturally aggregate in flocks and granules ${ }^{[39]}$. The granules have a high density, excellent mechanical strength, and a high settling velocity in combination with a high specific methanogenic activity. The granules form a blanket through which the influent wastewater flows. Organic substances in the wastewater are digested by anaerobic microbes, while the wastewater flows through this sludge blanket. As a result of anaerobic digestion of the organic substances, biogas consisting of methane, carbon dioxide, hydrogen, nitrogen, hydrogen sulfide, etc. is generated ${ }^{[40]}$. The optimal operational conditions of upflow velocity, influent $\mathrm{COD}, \mathrm{pH}$ and temperature are needed for an efficient biological treatment of wastewater to produce biogas in the UASB reactor ${ }^{[47]}$. Due to its high biomass concentrations, the conversion rate in UASB is several times higher than that in conventional anaerobic processes $^{[40]}$. 
Natural turbulence caused by the influent flow rate and biogas production provides good wastewater biomass-contact in UASB systems ${ }^{[39]}$. Neither mechanical mixing within the reactor nor recirculation of sludge and effluent is needed, resulting in little external energy requirement [40].

Numerous studies on small and large scale UASB processes have been rapidly recognized as a good option in the treatment of sewage ${ }^{[40]}$. Although this technology cannot by itself produce an effluent of the quality of a convention secondary process like activated sludge, it can still achieve significant organic matter removal rates in the range of $60-75 \%$ of $\mathrm{BOD}_{5}$ at a fraction of the construction, operating and maintenance costs of activated sludge ${ }^{[1]}$.

Among existing anaerobic treatment processes, the UASB process has to a large extent proven to satisfy the factors. The positive factors have made UASB an attractive option for the treatment of municipal sewage in developing countries because of the warm climatic conditions $[39,40,48]$. However, UASB treatments also have disadvantages. The main advantages and disadvantages of UASB reactors used for the treatment of domestic wastewater are described in Table $3^{[10,39,40,49]}$.

Table 3. Advantages and disadvantages of UASB reactors.

\section{UASB advantages}

Good removal efficiency, even at high loading rates and low temperatures.

Construction and operation relatively simple.

Highly skilled personnel for its operation not required.

Process tolerant of flow variations or shock loads.

High strength wastewater can be treated with no energy penalty.

Sludge production lower compared to conventional aerobic methods, due to the slow growth rates of anaerobic bacteria.

Low nutrients and chemical requirement.

\section{UASB disadvantages}

Long startup takes before steady state operation, due to the low growth rate of methanogenic organisms. Hydrogen sulfide is produced and a proper handling of the biogas is required. Loss of dissolved methane in the effluent (loss of energy and high global warning potential). Proper temperature control (15-35 $\mathrm{O}$ ) required for colder climates. Post-treatment of the effluent is generally required to reach the discharge standards for organic matter, nutrients and pathogens.

\subsubsection{Anaerobic Membrane Bioreactors (AnMBR).}


Anaerobic membrane technology brings together the advantages of anaerobic processes with the production of solid free effluent, which provides an appropriate alternative to complete biomass retention, enabling short hydraulic residence time (HRT) and high solid retention time $(\mathrm{SRT})^{[46,49,50]}$. As a consequence, the particulate organics retained in the reactor can eventually be hydrolyzed and decomposed because of the long solids retention time. Also the AnMBR allows the anaerobic microbes proliferate without being washed out from the process ${ }^{[46]}$. One of the goals of anaerobic treatment processes is to maintain a long SRT because of the slow growth rate of anaerobic microorganisms, especially when operating at psychrophilic conditions and with low strength wastewater, such as domestic wastewater ${ }^{[49]}$. AnMBRs have been demonstrated to be capable of achieving high effluent quality in terms of suspended solids, chemical oxygen demand (COD), and pathogen count, even at low temperatures, thus demonstrating their potential for meeting more rigorous effluent quality requirements ${ }^{[41,49]}$.

\subsection{AnMBR + N REMOVAL.}

The effluents from anaerobic reactors rarely meet discharge standards for wastewater reuse due to the kinetic limitations of anaerobic metabolism. In contrast to the high COD and TSS elimination, the removal of nitrogen or phosphorus in the AnMBR systems is usually negligible. The low removal of nitrogen and phosphorus is expected because both nutrients removal processes required anoxic or aerobic zone. This can be beneficial if the effluent is to be used for agriculture or irrigation purpose. However, in most cases, this means that the downstream treatment is needed if the effluent is to be reclaimed ${ }^{[51]}$.

The anaerobic effluents reactors usually require a post-treatment step as a means to adapt the treated effluent to the requirements of the environmental legislation and protect the receiving water bodies ${ }^{[52,53]}$. The main role of the post-treatment is to complete the removal of organic matter, as well as to remove constituents little affected by the anaerobic treatment, such as nutrients ( $\mathrm{N}$ and $\mathrm{P}$ ) and pathogenic organisms (viruses, bacteria, protozoans and helminths) ${ }^{[52]}$.

When nitrogen removal has to be accomplished, the application of nitrificationdenitrification processes are so far selected to complement the UASB reactor ${ }^{[54]}$. In such case, the anaerobic reactor should be used to treat initially only a part of the influent raw sewage (possibly no more than $50-70 \%$ ), and the remaining part (30-50\%) should be directed to the complementary biological treatment, aiming at nitrification and denitrification, so that there is 
enough organic matter for the denitrification step ${ }^{[52,54]}$.

To couple with nitrogen removal limitation, anaerobic membrane bioreactors can play an important role with post-treatment systems based on biofilters, sponge-bed filters and sequencing batch reactors among others.

Among the different possible types of post-treatment for the removal of nitrogen, down below, sequencing batch systems and biofilters are presented.

\subsubsection{Sequencing batch systems}

Sequencing batch reactors (SBR) are considered as fill and draw version of the activated sludge process. SBRs are basically suspended growth biological wastewater treatment reactors, in which all the metabolic reactions and solid-liquid separation takes place in one tank and in a well-defined and continuously repeated time sequence. ${ }^{[55]}$.

The first activated sludge systems were composed of a single reactor that processed sequential batches of wastewater for a certain period while aeration was applied. This was followed by a period in which the aeration was switched off, which transformed the reactor into a settler. From there, the effluent was discharged and a new batch could be taken in. SBR operates under a series of periods that constitute a cycle. The cycle generally consists of fill, react, settle, discharge and an optional period of pause (see Figure 5$)^{[20,55]}$.

(1) Fill: a wastewater batch is fed to the sludge mass already present in the tank from the previous cycle. During this phase the aerator may or may not be switched on.

(2) React: Reactions for substrate removal initiated during fill are completed during react. The treatment is controlled by air, either on or off, to produce anoxic and aerobic conditions. Controlling the time of mixing and/or aeration produces the degree of treatment required.

(3) Settle: sludge settling in the reactor. The entire tank acts as a clarifier without any inflow or outflow. Aeration and/or mixers off.

(4) Discharge: the clarified supernatant (treated effluent) is discharged from the reactor as effluent and, if required, excess sludge is withdrawn as well.

(5) Pause: optional phase which is generally required when several SBRs are in operation. 


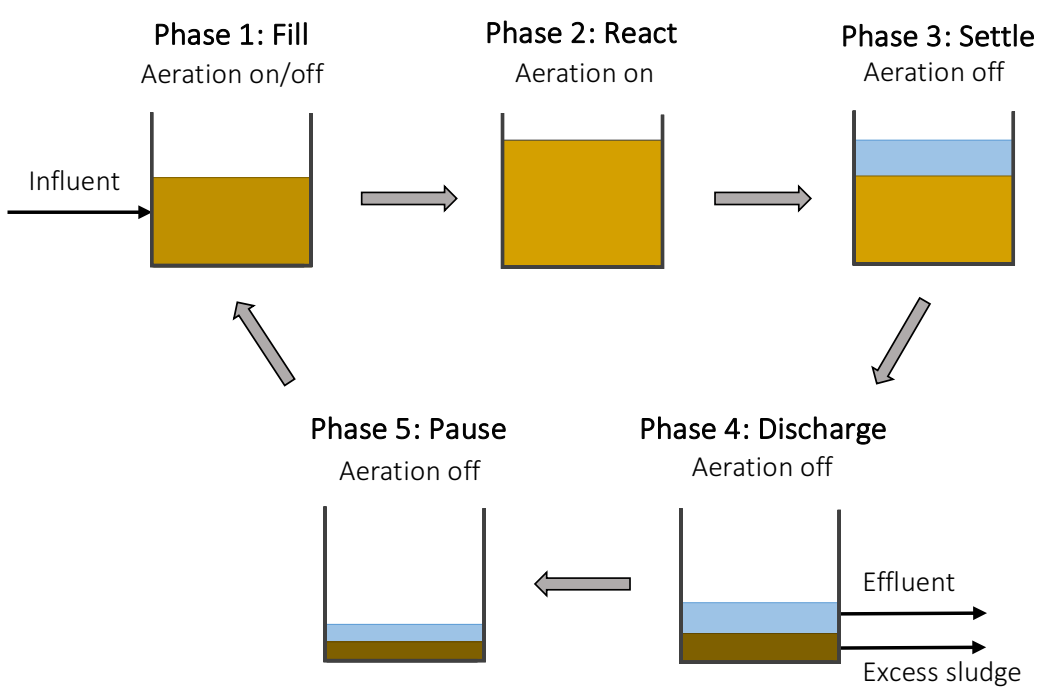

Figure 5: Typical operational cycle of a sequential batch reactor (SBR).

Multifunctional SBR, allows the removal of not only the remaining COD but also nutrients. The carbon and nutrient removal efficiencies of in SBR vary with the duration of the cycle time and time for each phase of the process in a cycle of operation. The cycle time dictates the number of cycles per day, the volume of reactor required and the cost of the WWT system and is based on the strength of the wastewater. Normally, the system as batch process does not require secondary clarifier and pumping of return activated sludge ${ }^{[20,56,57]}$.

The SBR processes are known to save more than $60 \%$ of the expenses required for conventional activated sludge process in operating cost and achieve high effluent quality in a very short aeration time ${ }^{[55]}$. SBR technology is more advantageous than the extended aeration process due to higher COD and $N$ removal rates at comparatively shorter HRT. Other advantages attributed to SBR apart of the good effluent quality, are the simplicity of operation and the lower investment costs, due to the absence of a final settler. One disadvantage that is often attributed to SBR systems is the inflexibility in dealing with flow variations, as the SBR only receives influent during a minor part of the total cycle time ${ }^{[20,58]}$.

Conventional activated sludge systems are space oriented. Wastewater flow moves from one tank into the next on a continuous basis and virtually all tanks have a predetermined liquid volume. The SBR, on the other hand, is a time-oriented system, with pre determined flow, energy input and tank volume varying according to some predetermined, periodic operating strategy ${ }^{[56,59]}$.

In its original version, the activated sludge process was operated as a batch process. Although this activated sludge process has been replaced gradually by other configurations, it 
has survived in the form of SBR. The SBR has regained popularity over the last decades, especially for application to smaller wastewater streams ${ }^{[20]}$.

\subsubsection{Biofilters}

Biofiltration seems to be an interesting option for efficiently remove both residual organic matter and nutrients from domestic wastewater ${ }^{[60]}$.

The submerged aerated filters (SAFs) are biofilm systems in which a biofilm support medium is submerged in wastewater to create a large contact area for aerobic biological treatment ${ }^{[61,}$ ${ }^{62]}$. Due to the immobilization of biomass on media, the loss of biomass by shearing is the only mechanism for the escape of biosolids in the bioreactor effluent. The sloughed biomass has good settling characteristics and can be readily separated from the liquid ${ }^{[63]}$. As organic matter and nutrients are absorbed from the wastewater, the film of biological growth grows and thickens ${ }^{[64]}$.

There are two main configurations for denitrification filters commercially available: down flow and up flow continuous backwash filters. Down flow denitrification filters operate in a conventional filtration mode and consist of media and support gravel laying on an underdrain. In up flow continuous-backwash filters, wastewater flows upward through the filter, countercurrent to the movement of the sand bed ${ }^{[65]}$.

Biofiltration systems are typically robust, simple to construct and have low energy requirements ${ }^{[60,66]}$. The most salient advantages are: no problems with bulking sludge, high sludge age enables degradation of complex compounds and biofilm mitigates inhibition and toxic impacts ${ }^{[61,63]}$. The biofilter can be used in aerated and unaerated modes. Thus, these systems can be designed for carbon removal, nitrification and/or denitrification depending on process objectives $^{[61]}$.

\section{FINAL REMARKS}

Much progress has been achieved in the last years in terms of understanding the pollutants elimination from waste water. This progress has been accompanied and motivated by increasing legislation towards a cleaner and safer world. This represents a promising scenario to the waste water treatment companies and the technology developers in research institutes and universities. The current needs of the wastewater "system" point to the development of combined processes of pollutant abatement while transforming it into useful products. In 
addition, this development should be accompanied by intensified processes, getting compact apparatus able to run with high yields, and selectivity's. Improving the biology, mass transfer and chemistry of the process will allow the development of this king of process in reduced treatment times. At the end, compact and efficient processes allow a massive implementation of the technology in an economical way.

The main challenges of the nitrogen removal technology lie in the development of an adequate combination of biological reactor and organic matter usage, which allows: (a) COD elimination and its non-contaminant recycling to facilitates nitrogen elimination, (b) fast and selective reactor and (c) economically feasible configurations.

To address the problem involved with the nitrogen removal in domestic wastewater, in this $\mathrm{PhD}$ Thesis are developed different reactor configurations and different reaction ways to treat the effluent of an anaerobic reactor. 


\section{References}

1. M. Libhaber and Á. Orozco-Jaramillo, Sustainable Treatment and Reuse of Municipal Wastewater: For Decision Makers and Practicing Engineers, IWA Publishing Alliance House, 2012.

2. M. Henze, Biological Wastewater Treatment: Principles, Modelling and Design, IWA Pub., 2008.

3. A. M. Eilersen and M. Henze, Energy related to sustainable waste handling technology., Danish Research Centre for Organic Farming., 2002.

4. G. Tchobanoglous, F. L. Burton, H. D. Stensel, Metcalf and Eddy, Wastewater Engineering: Treatment and Reuse, McGraw-Hill Education, 2003.

5. G. Z. Teklehaimanot, M. A. A. Coetzee and M. N. B. Momba, Faecal pollution loads in the wastewater effluents and receiving water bodies: a potential threat to the health of Sedibeng and Soshanguve communities, South Africa, Environmental Science and Pollution Research, 2014, 21(16), p.9589-9603.

6. B. D. Shoener, I. M. Bradley, R. D. Cusick and J. S. Guest, Energy positive domestic wastewater treatment: the roles of anaerobic and phototrophic technologies, Environ. Sci.: Processes Impacts, 2014, 16(6), p.1204-1222.

7. M. Palaniappan, P. H. Gleick, L. Allen, M. J. Cohen, J. Christian-Smith and C. Smith, Clearing the waters: a focus on water quality solutions, United Nations Environment Programme (UNEP), Nairobi, Kenya, 2010.

8. N. M. DEMIR, E. DEBIK and T. COŞKUN, Municipal wastewater treatment with a pilot scale two-stage cascade biological nutrient removal process, Sigma, 2016, 34(1), p.7179.

9. C. Gonçalves Athanásio, D. Prá and A. Rieger, Water Quality of Urban Streams: The Allium cepa Seeds/Seedlings Test as a Tool for Surface Water Monitoring, The Scientific World Journal, 2014, 20147.

10. G. L. Karia and R. A. Christian, Wastewater Treatment: Concepts and Design Approach, PHI Learning, 2013.

11. H. Ozgun, R. K. Dereli, M. E. Ersahin, C. Kinaci, H. Spanjers and J. B. v. Lier, A review of anaerobic membrane bioreactors for municipal wastewater treatment: Integration options, limitations and expectations, Separation and Purification Technology, 2013, 11889 - 104.

12. D. Mara, Domestic Wastewater Treatment in Developing Countries, Taylor \& Francis, 2013. 
13. I. L. Pepper, C. P. Gerba, T. J. Gentry and R. M. Maier, Environmental Microbiology, Elsevier Science, 2011.

14. C. Sophonsiri and E. Morgenroth, Chemical composition associated with different particle size fractions in municipal, industrial, and agricultural wastewaters, Chemosphere, 2004, 55(5), p.691-703.

15. M.-h. Huang, Y.-m. Li and G.-W. Gu, Chemical composition of organic matters in domestic wastewater, Desalination, 2010, 262(1-3), p.36-42.

16. S. Vigneswaran, Waste Water Treatment Technologies - Volume I, EOLSS Publ., 2009.

17. S. Aiyuk, J. Amoako, L. Raskin, A. v. Haandel and W. Verstraete, Removal of carbon and nutrients from domestic wastewater using a low investment, integrated treatment concept, Water Research, 2004, 38(13), p.3031 - 3042.

18. K. Stamatelatou and K. P. Tsagarakis, Sewage Treatment Plants: Economic Evaluation of Innovative Technologies for Energy Efficiency, International Water Assn, 2015.

19. A. Goldoni, C. Golfeto, J. B. Teixeira, G. Blumm, C. M. Wilhelm, F. Telöken, E. Bianchi, J. L. Schmitt, G. Gehlen, M. A. S. Rodrigues and L. B. da Silva, Cytotoxic and genotoxic evaluation and chemical characterization of sewage treated using activated sludge and a floating emergent-macrophyte filter in a municipal wastewater treatment plant: a case study in Southern Brazil, Environmental Earth Sciences, 2014, 72(5), p.1503-1509.

20. A. C. van Haandel and J. G. M. van der Lubbe, Handbook of Biological Wastewater Treatment: Design and Optimisation of Activated Sludge Systems, IWA Pub., 2012.

21. P. S. Davies, The biological basis of wastewater treatment, Strathkelvin Instruments Ltd, 2005.

22. Y. J. Chan, M. F. Chong, C. L. Law and D. G. Hassell, A review on anaerobic-aerobic treatment of industrial and municipal wastewater, Chemical Engineering Journal, 2009, 155(1-2), p.1-18.

23. CHD, Guía práctica para la depuración de aguas residuales en pequeñas poblaciones, Confederación Hidrográfica del Duero. Ministerio de Agricultura, Alimentación y Medio Ambiente. Gobierno de España, 2013.

24. Y. Liu, Chemically reduced excess sludge production in the activated sludge process, Chemosphere, 2003, 50(1), p.1-7.

25. D. Fatta-Kassinos, D. D. Dionysiou and K. Kümmerer, Advanced Treatment Technologies for Urban Wastewater Reuse, Springer International Publishing, 2016.

26. A. Azhdarpoor, P. Mohammadi and M. Dehghani, Simultaneous removal of nutrients in a novel anaerobic-anoxic/aerobic sequencing reactor: removal of nutrients in a novel 
reactor, International Journal of Environmental Science and Technology, 2015, 13(2), p.543-550.

27. S.-P. Sun, C. Pellicer i Nàcher, B. Merkey, Q. Zhou, S. Q. Xia, D. H. Yang, J. H. Sun and B. F. Smets, Effective Biological Nitrogen Removal Treatment Processes for Domestic Wastewaters with Low C/N Ratios: A Review, Environmental Engineering Science, 2010, 27(2), p.111-126.

28. M. Ruscalleda Beylier, M. D. Balaguer, J. Colprim, C. Pellicer-Nàcher, B. J. Ni, B. F. Smets, S. P. Sun and R. C. Wang, in Comprehensive Biotechnology (Second Edition), ed. M. MooYoung, Academic Press, Burlington, 2011, pp. 329-340.

29. R. J. Seviour and P. H. Nielsen, Microbial Ecology of Activated Sludge, IWA Publishing, 2010.

30. M. Hatamoto, K. Ohtsuki, N. Maharjan, S. Ono, K. Dehama, K. Sakamoto, M. Takahashi and T. Yamaguchi, Performance evaluation of the sulfur-redox-reaction-activated upflow anaerobic sludge blanket and down-flow hanging sponge anaerobic/anoxic sequencing batch reactor system for municipal sewage treatment, Bioresource Technology, 2016, 204171 - 176.

31. J. Zhang, W. Jia, R. Wang, H. H. Ngo, W. Guo, H. Xie and S. Liang, Microbial community characteristics during simultaneous nitrification-denitrification process: effect of COD/TP ratio, Environmental Science and Pollution Research, 2015, 23(3), p.2557-2565.

32. G. Vijayan, R. Saravanane and T. Sundararajan, Influence of Nitrogen Residue on the Performance of Sequencing Batch Reactor (SBR) in Wastewater Treatment - A Review, International Journal of Environmental Monitoring and Protection, 2016, 3(1), p.1-16.

33. M. Seifi and M. H. Fazaelipoor, Modeling simultaneous nitrification and denitrification (SND) in a fluidized bed biofilm reactor, Applied Mathematical Modelling, 2012, 36(11), p.5603-5613.

34. D. Wei, X. Xue, L. Yan, M. Sun, G. Zhang, L. Shi and B. Du, Effect of influent ammonium concentration on the shift of full nitritation to partial nitrification in a sequencing batch reactor at ambient temperature, Chemical Engineering Journal, 2014, 23519 - 26.

35. F. Fatone, M. Dante, E. Nota, S. Di Fabio, N. Frison and P. Pavan, Biological short-cut nitrogen removal from anaerobic digestate in a demonstration sequencing batch reactor, Chem Eng Trans, 2011, 241135-1140.

36. C. Wu, Z. Chen, X. Liu and Y. Peng, Nitrification-denitrification via nitrite in SBR using real-time control strategy when treating domestic wastewater, Biochemical Engineering Journal, 2007, 36(2), p.87 - 92. 
37. P. L. McCarty, J. Bae and J. Kim, Domestic Wastewater Treatment as a Net Energy Producer-Can This be Achieved?, Environmental Science \& Technology, 2011, 45(17), p.7100-7106.

38. L. Zhang, P. Zheng, C.-j. Tang and R.-c. Jin, Anaerobic ammonium oxidation for treatment of ammonium-rich wastewaters, Journal of Zhejiang University. Science. B, 2008, 9(5), p.416-426\%W PMC2367381.

39. M. A. Latif, R. Ghufran, Z. A. Wahid and A. Ahmad, Integrated application of upflow anaerobic sludge blanket reactor for the treatment of wastewaters, Water Research, 2011, 45(16), p.4683 - 4699.

40. H. H. P. Fang, Environmental Anaerobic Technology: Applications and New Developments, 2010.

41. R. Yoo, J. Kim, P. McCarty and J. Bae, Effect of temperature on the treatment of domestic wastewater with a staged anaerobic fluidized membrane bioreactor, Water science \& Technology, 2014, 69(6), p.

42. E. J. Bowen, J. Dolfing, R. J. Davenport, F. L. Read and T. P. Curtis, Low-temperature limitation of bioreactor sludge in anaerobic treatment of domestic wastewater, Water Science and Technology, 2014, 69(5), p.1004-1013.

43. D.-W. Gao, Q. Hu, C. Yao, N.-Q. Ren and W.-M. Wu, Integrated anaerobic fluidized-bed membrane bioreactor for domestic wastewater treatment, Chemical Engineering Journal, 2014, 240362 - 368.

44. R. Yoo, J. Kim, P. L. McCarty and J. Bae, Anaerobic treatment of municipal wastewater with a staged anaerobic fluidized membrane bioreactor (SAF-MBR) system, Bioresource Technology, 2012, 120133 - 139.

45. X. Yue, Y. K. K. Koh and H. Y. Ng, Effects of dissolved organic matters (DOMs) on membrane fouling in anaerobic ceramic membrane bioreactors (AnCMBRs) treating domestic wastewater, Water Research, 2015, 8696 - 107.

46. B. Lew, S. Tarre, M. Beliavski, C. Dosoretz and M. Green, Anaerobic membrane bioreactor (AnMBR) for domestic wastewater treatment, Desalination, 2009, 243(1-3), p.251 - 257.

47. A. M. Enitan, J. Adeyemo, F. M. Swalaha and F. Bux, Anaerobic Digestion Model to Enhance Treatment of Brewery Wastewater for Biogas Production Using UASB Reactor, Environmental Modeling \& Assessment, 2015, 20(6), p.673-685.

48. N. Khalil, R. Sinha, A. Raghav and A. Mittal, 2008.

49. J. Gouveia, F. Plaza, G. Garralon, F. Fdz-Polanco and M. Peña, A novel configuration for an anaerobic submerged membrane bioreactor (AnSMBR). Long-term treatment of 
municipal wastewater under psychrophilic conditions, Bioresource Technology, 2015, 198510-519.

50. J. Bae, R. Yoo, E. Lee and P. McCarty, Two-stage anaerobic fluidized-bed membrane bioreactor treatment of settled domestic wastewater, Water Sci. Technol, 2013, 68(2), p.394-399.

51. H. Lin, W. Peng, M. Zhang, J. Chen, H. Hong and Y. Zhang, A review on anaerobic membrane bioreactors: Applications, membrane fouling and future perspectives, Desalination, 2013, 314169 - 188.

52. C. A. L. Chernicharo, Post-treatment options for the anaerobic treatment of domestic wastewater, Reviews in Environmental Science and Biotechnology, 2006, 5(1), p.73-92.

53. A. Kumar Mungray, Z. V. P. Murthy and A. J. Tirpude, Post treatment of up-flow anaerobic sludge blanket based sewage treatment plant effluents: A review, Desalination and Water Treatment, 2010, 22(1-3), p.220-237.

54. C. A. L. Chernicharo, J. B. van Lier, A. Noyola and T. Bressani Ribeiro, Anaerobic sewage treatment: state of the art, constraints and challenges, Reviews in Environmental Science and Bio/Technology, 2015, 14(4), p.649-679.

55. M. Singh and R. K. Srivastava, Sequencing batch reactor technology for biological wastewater treatment: a review, Asia-Pacific Journal of Chemical Engineering, 2011, 6(1), p.3-13.

56. R. Pannirselvam and Y. Ibrahim, Simultaneous carbon and nutrien removal from dairy wastewater in sequencing batch reactor (SBR), 2015.

57. E. Foresti, M. Zaiat and M. Vallero, Anaerobic Processes as the Core Technology for Sustainable Domestic Wastewater Treatment: Consolidated Applications, New Trends, Perspectives, and Challenges, Reviews in Environmental Science and Bio/Technology, 2006, 5(1), p.3-19.

58. R. Ganesh, P. Sousbie, M. Torrijos, N. Bernet and R. A. Ramanujam, Nitrification and denitrification characteristics in a sequencing batch reactor treating tannery wastewater, Clean Technologies and Environmental Policy, 2014, 17(3), p.735-745.

59. S. Vigneswaran, Waste Water Treatment Technologies - Volume II, EOLSS Publ., 2009.

60. A. Nogueira, J. Bassin, A. Cerqueira and M. Dezotti, Integration of biofiltration and advanced oxidation processes for tertiary treatment of an oil refinery wastewater aiming at water reuse, Environmental Science and Pollution Research, 20161-12.

61. A. Jácome, J. Molina, R. Novoa, J. Suárez and S. Ferreiro, Simultaneous carbon and nitrogen removal from municipal wastewater in full-scale unaerated/aerated submerged filters, Water science \& Technology, 2014, 69(1), p. 
62. A. Ramos, M. Gomez, E. Hontoria and J. Gonzalez-Lopez, Biological nitrogen and phenol removal from saline industrial wastewater by submerged fixed-film reactor, Journal of Hazardous Materials, 2007, 142(1), p.175-183.

63. G. Nakhla, J. Zhu and Y. Cui, Liquid-solid circulating fluidized bed waste water treatment system for simultaneous carbon, nitrogen and phosphorus removal, 2007.

64. R. L. Pehrson, W. J. Flournoy and S. B. Hubbell, Wastewater treatment method, 2010.

65. A. G. Capodaglio, P. Hlavínek and M. Raboni, Advances in wastewater nitrogen removal by biological processes: state of the art review, Revista Ambiente \& Água, 2016, 11(2), p.250-267.

66. J. Reungoat, B. Escher, M. Macova, M. J. Farré, F. X. Argaud, P. G. Dennis, W. Gernjak and J. Keller, Biofiltration for Advanced Treatment of Wastewater, 2012. 


\section{Aims and Contents}

Nitrogen removal in domestic wastewater after anaerobic treatment 


\section{Outlook}

The increasing urban growth, the unsustainable use of the natural resources and the society awareness of the environmental impact, highlight the necessity to develop and implement advanced technologies aimed to prevent, mitigate and correct the pollution problems derived from anthropogenic origin. Currently, one key environmental problem is the wastewater production.

Organic matter and nutrients present in domestic wastewater should be removed or valorized to reduce its impact on the environment. Conventional wastewater treatments are focused on the removal of these pollution sources at the minimum cost. The idea of resource recovery from wastewater is changing the concept of the conventional wastewater treatment plants that tend to incorporate little by little processes as anaerobic digestion.

Anaerobic treatment processes are well-known to achieve high organic matter removal efficiencies without oxygen requirement, low biomass production and energy generation from biogas. The growing interest in anaerobic treatment of domestic wastewater requires a parallel approach in the development of downstream technologies because the effluent often requires a post-treatment to remove nutrients, especially nitrogen.

Nitrogen removal has become one of the most significant cost factors a wastewater facility faces. To comply with the regulations, facilities are confronted with major plant upgrades that include nitrification and denitrification. These systems typically require significant space, substantial capital upgrades, and impact both energy and chemical operational costs.

As it was analyzed in State of the Art, the main challenges of the nitrogen removal technology lie in the development of a fast and selective biological reactor that allows an adequate electron donors usage with an economically feasible configuration. The accomplishment of this goal was analyzed in this PhD Thesis by using different reactor configurations as well as different reaction ways.

The aim of this PhD Thesis is to develop and evaluate different treatment processes of an anaerobic reactor effluent fed with domestic wastewater.

The AIM OF THIS WORK is to develop and evaluate different treatment processes of an anaerobic reactor effluent fed with domestic wastewater. For this purpose, nitrogen removal 
efficiency and environmental sustainability have been considered to comply the discharge standards in domestic wastewater.

In order to accomplish the general aim of this thesis, the following partial objectives were established:

- Design and construction of a SBR process to remove nitrogen of a domestic wastewater previously treated in an anaerobic reactor at $18 \stackrel{\circ}{ } \mathrm{C}$.

- Study of different cycles and determination of the optimum.

- Design and construction of a fixed film bioreactor for partial and total denitrification of the effluent from an anaerobic reactor treating domestic water under psychrophilic conditions.

- Feasibility of the removal of nitrates and nitrite using methane, sulfide and organic matter as electron donors to remove nitrates and nitrites at different HRT.

- Study of the influence of the $\mathrm{NO}_{2} / \mathrm{NO}_{3}$ ratio in the feed.

- Design and construction of a denitrification/nitrification pilot plant treating domestic wastewater after anaerobic treatment.

- Study the influence evaluation of the $\mathrm{COD} / \mathrm{N}$ ratio and the nitrate recycling ratio in nitrogen removal.

- Evaluate the economical feasibility of the nitrogen elimination technology.

- Comparison of a conventional denitrification/nitrification and denitritation/nitritation process as a post-treatment of membrane anaerobic effluent.

- Search of the sensitive parameter that can be modified to get the biggest conversion of nitrite to nitrogen gas in the denitritation process

In order to achieve the objectives of this thesis, the work was structured in five chapters. In each of them, the partial objectives and challenges are presented. In each chapter, a literature review was done in order to know the main achievements and challenges of the analyzed study. 
The main content of the chapters is described below.

In Chapter 1, "SBR process for nitrogen removal of a domestic wastewater from anaerobic treatment", the performance of SBR is presented to treat the effluent of an anaerobic reactor. The $5 \mathrm{~L}$ of working volume was investigated at different cycle times of $12 \mathrm{~h}, 8 \mathrm{~h}$ and $6 \mathrm{~h}$, at 18 oc, and the $6 \mathrm{~h}$ cycle time was selected as the optimal for the treatment. Results from nitrification and denitrification of domestic wastewater in the SBR showed COD and nitrogen removal efficiencies of about $73 \%$ and $81 \%$. The process was successful in an anoxic/aerobic/anoxic cycle sequence with the addition of methanol just before the second anoxic stage.

In Chapter 2, "Denitrification of the AnMBR effluent with alternative electron donors in domestic wastewater treatment", the performance of a fixed film bioreactor for partial and total denitrification was investigated. Wastewater after anaerobic treatment contains a remaining COD not enough for the conventional heterotrophic denitrification. As the effluent from the low-temperature anaerobic reactor holds methane and sulfide, it was evaluated the feasibility of using them as electron donors to remove $\mathrm{NO}_{2}$ and $\mathrm{NO}_{3}$ at different $\mathrm{HRT}$, obtaining the optimum at $2 \mathrm{~h}$. In addition, the influence of the $\mathrm{NO}_{2} / \mathrm{NO}_{3}$ ratio in the feed was studied. Nitrogen removal was demonstrated obtaining a successful $\mathrm{NO}_{2}$ and $\mathrm{NO}_{3}$ elimination when the feed was $80 \mathrm{mg} \mathrm{N}-\mathrm{NO}_{*} / \mathrm{L}$, except when the feeding was formed only by nitrate, that the process was at the limit. Methane was the main electron donor used to remove $\mathrm{NO}_{2}$ and $\mathrm{NO}_{3}$, with more than $70 \%$ or participation.

In Chapter 3, "Advanced denitrification of anaerobic treatment effluent of domestic wastewater by using wasted gas", the denitritation process using alternative electron donors present in the water at $18 \stackrel{\circ}{\circ}$ and $2 \mathrm{~h}$ of HRT was investigated. Different synthetic nitrite concentrations were supplied to the anoxic reactor to simulate the effluent of a nitritation process. The results demonstrated that the process was able to remove around $95 \%$ and $93 \%$ of nitrite when the inlet was $50 \mathrm{mg} \mathrm{NO}-\mathrm{N} / \mathrm{L}$ and $75 \mathrm{mg} \mathrm{NO}{ }_{2}^{-}-\mathrm{N} / \mathrm{L}$ from a simulated recirculation of aerobic treatment effluent. For high inlet concentrations of $\mathrm{NO}_{2}$, recirculation of the gas collected in the anoxic reactor was a successful solution, thus achieving a nitrite removal efficiency upper than $98 \%$ when the nitrite concentration in the feed was $95 \mathrm{mg} \mathrm{NO} \mathrm{N}_{2}^{-} \mathrm{N} / \mathrm{L}$.

In Chapter 4, "Nitrogen removal in domestic wastewater. Effect of nitrate recycling and COD/N ratio", a denitrification/nitrification pilot plant was designed, built and operated to examine the effect of the nitrate recycling and the $\operatorname{COD} / \mathrm{N}$ ratio on the nitrogen and the 
remaining organic matter removal. The system consisted of an anoxic reactor and an aerobic one, with HRTs of $2 \mathrm{~h}$ and $4 \mathrm{~h}$, respectively. The increase in the nitrate recycling ratio did not suppose a significant improvement in the nitrogen removal due to the insufficient carbon source. The addition of methanol was a key point in the denitrification process. The maximum nitrogen and organic matter removal ( $85 \%$ and $96 \%$, respectively) was achieved with a nitrate recycling ratio of $600 \%$ and a $\mathrm{C} / \mathrm{N}$ of 8.25 , adjusted by methanol addition. Actually, instead of the addition of methanol, the enhancement of the $C / D$ ratio can be made by bypassing part of the feedstream from a point before the anaerobic treatment to another point in the end of this reactor.

In Chapter 5, "Techno-economical study of a domestic wastewater treatment system", the techno-economical feasibility of the nitrogen elimination technology with a MBR pre-treatment was simulated. The influence of different electron donors (methane, organic matter and sulfide) on the nitrogen removal capacity was analyzed. Different scenarios have been assessed changing the concentration of the involved components and evaluating their effect on the nitrogen removal capacity as well as the ability to produce biogas in the anaerobic treatment. These scenarios imply on the one hand, the increment of the available soluble COD for the nitrogen elimination stage; On the other hand, different flows of biogas from the anaerobic reactor were pumped to the denitritation reactor. The goal was to achieve a nitrogen removal capacity to reach an effluent with $10-20 \mathrm{mg} \mathrm{N} / \mathrm{L}$. Then, the most promising scenario was studied in detail and it was compared to the costs associated to the WWTP with a biological MBR anaerobic treatment. The results indicated that the proposed process is feasible since the fixed and variables costs of both treatment plants are similar.

This work is part of the IPT-2011-1078-310000 research project within the INNPACTO 2011 program funded by the Ministry of Economy and Competitiveness, the European Regional Development Fund, and the company Cadagua S.A. 


\title{
Chapter 2. SBR system for nitrogen removal in domestic wastewater from anaerobic treatment.
}

\begin{abstract}
This work presents the performance of a sequencing batch reactor (SBR) system used as nitrogen $(\mathrm{N})$ removal treatment of domestic wastewater previously treated with an anaerobic reactor and as consequence, with a low $\mathrm{C} / \mathrm{N}$ ratio. The aim of the work was to determine the feasibility for the removal of nitrogen from the domestic wastewater. A $5 \mathrm{~L}$ of working volume SBR was investigated at different cycle times of $12 \mathrm{~h}, 8 \mathrm{~h}$ and $6 \mathrm{~h}$, at $18 \stackrel{\circ}{ } \mathrm{C}$. The treatment efficiency of SBR varied with the duration of the cycle time, being optimal the anoxic/aerobic/anoxic sequence cycle with $6 \mathrm{~h}$ of duration. Due to the low organic matter present in the domestic wastewater after anaerobic treatment, an additional supply of external carbon before the second anoxic stage was necessary. The addition of methanol was a key point in the denitrification process employed as a model for the wastewater by-pass in wastewater treatment plants (WWTP). The removal efficiencies obtained were: $98 \%$ for total Kjeldahl nitrogen (TKN) and 84\% for total nitrogen (TN) and 77\% for soluble chemical oxygen demand (COD). The reactor showed viability, so this process can be successfully applied as a post-treatment of an anaerobic reactor treating domestic wastewater, for the removal of nitrogen.
\end{abstract}

Keywords: Denitrification - Nitrification - Nitrogen removal • Organic matter $\bullet$ Sequencing batch reactor. 


\section{INTRODUCTION}

Conventional activated sludge treatment, commonly used to treat domestic wastewater, causes problems such as excessive generation of sludge and involves consumption of a large amount of energy ${ }^{[1,2]}$. In contrast, anaerobic biological treatment has a number of advantages favoring energy balances because of the reduced sludge production, , the not requirement of aeration and the energy recovery as methane gas ${ }^{[2-4]}$.

The anaerobic reactors treating domestic wastewater can produce two main valuable products, which can be recovered and utilized: methane and the effluent. The methane gas, which is produced during the COD removal can be recovered and transformed into energy ${ }^{[5]}$. The effluent contains solubilized organic matter, high ammonia-nitrogen and organic-nitrogen concentrations. Therefore, application of a post-treatment process is necessary in order to remove nutrients from the wastewater and achieve the desired effluent quality ${ }^{[2,6,7]}$. Advancing treatment of domestic wastewater requires implementing energy efficient nitrogen removal technologies that avoid nullify the energy savings realized from the anaerobic process. This process also mitigates greenhouse gas emissions and maintains or reduces the footprint ${ }^{[4,5]}$.

Biological nutrient removal (BNR) constitutes the most economical and sustainable technique for removing organic carbon and nitrogen, and then, to meet rigorous discharge requirements ${ }^{[8-10]}$. The biological nitrogen $(N)$ removal involves two processes: nitrification and denitrification. Nitrification is an aerobic process performed by autotrophic bacteria, in which ammonium $\left(\mathrm{NH}_{4}^{+}\right)$is oxidized to nitrite $\left(\mathrm{NO}_{2}{ }^{-}\right)$, by means of ammonium oxidizing bacteria (AOB). Then, nitrite is oxidized to nitrate $\left(\mathrm{NO}_{3}{ }^{-}\right)$by nitrite oxidizing bacteria ${ }^{[2]}$. Denitrification is an anoxic process performed by a functional group of bacteria that use oxidized nitrogen as electron acceptor in respiration. In this process, $\mathrm{NO}_{3}{ }^{-}$is reduced to $\mathrm{NO}_{2}{ }^{-}$and then to nitric oxide (NO), nitrous oxide $\left(\mathrm{N}_{2} \mathrm{O}\right)$ and finally to molecular nitrogen $\left(\mathrm{N}_{2}\right)^{[8,10]}$.

Both nitrification and denitrification possess nitrite $\left(\mathrm{NO}_{2}^{-}\right)$as an intermediate. Hence, if nitrification is stopped at nitrite (nitritation), then complete denitritation from nitrite to nitrogen gas can be achieved. Nitritation-denitritation may save $25 \%$ of aeration consumption and $40 \%$ of chemical oxygen demand (COD), as well as low biomass production and increased kinetic. However, the difficulty to utilize nitrogen removal via nitrite lies in achieving specific inhibition of the nitrite oxidizing bacteria while retaining ammonia oxidizing bacteria, thereby attaining nitritation ${ }^{[11-13]}$. 
The biological process with an anaerobic-aerobic-anoxic system is a feasible and sustainable technology for removing nitrogen and organic matter from domestic wastewater. High organic and ammonium removal efficiencies are achieved by using this systems, but the total nitrogen (TN) removal efficiency is not high due to the shortage of carbon source available for denitrification ${ }^{[9]}$. Organic substrates such as methanol can be used for carbon and electron source for biological denitrification ${ }^{[14,15]}$. The main disadvantage of using methanol is the safety issues associated with its transportation, handling, and storage ${ }^{[16]}$. One of the most effective methods to increase the organic matter concentration of the influent without the addition of external organic substrates is achieved by mixing a fraction of the influent to the anaerobic reactor with the effluent of that reactor. In such case, the anaerobic reactor should be used to treat initially only a part of the influent raw sewage (possibly no more than 50-70\%), and the remaining part $(30-50 \%)$ should be directed to the complementary biological treatment. The use of this "by-pass" will increase the COD of the reactor effluent making it more adequate to the next denitrification stage ${ }^{[17,18]}$.

SBR is a flexible system that has been used successfully for developing the classical nitrification and denitrification process ${ }^{[19]}$. The SBR is a fill and draw type modified activated sludge process that operates under a series of periods that constitute a cycle. Four basic steps of filling, reaction, settling and discharge phases take place sequentially in a single batch reactor. The SBR process offers minimum operator interaction, good oxygen contact with microorganisms and substrate, small floor space, good removal efficiency and the operation can be adjusted to obtain aerobic and anoxic conditions in the same tank ${ }^{[5,6]}$. In contrast to continuous systems, SBRs have become quite common for obtaining high nitrite accumulation due to the flexibility of process control ${ }^{[19]}$.

The main objective of the present study was the design and the feasibility of SBR process to remove nitrogen of a domestic wastewater previously treated in an anaerobic reactor.

\section{MATERIALS AND METHODS}

\subsection{Experimental Setup}

The lab-scale system developed for this study consisted on the one hand, of two reactors with a total volume of $1 \mathrm{~L}$. Air was supplied through porous diffusers at the bottom of each reactor to promote mixing and allowing a good diffusion of oxygen in the wastewater.

On the other hand, the system was developed with a SBR bioreactor and two tanks: feeding and effluent tanks. The reactor of $6 \mathrm{~L}$ of total volume and $5 \mathrm{~L}$ of working volume, was 
completely mixed with a mechanical stirrer and contained a fine bubble air diffuser, which was part of the aeration system. Two peristaltic pumps were used for the reactor filling and the effluent discharge. The two pumps, the stirrer and the aeration system were connected to an electric timer system. A schematic diagram of the SBR plant is given in Figure 1. The reactor was kept in a room under a controlled temperature of around $18 \stackrel{\circ}{ } \mathrm{C} \pm 1 \stackrel{\circ}{ } \mathrm{C}^{[20]}$. This was the working temperature of a previous anaerobic reactor that produced the effluent to treat. For the denitrification step, it was necessary the addition of methanol (1:100), supplied with another peristaltic pump. The addition of methanol was a model to simulate a by-pass of part of the feedstream from a point before the anaerobic reactor, to another point just in the end of it. The reactor was operated during 730 days.

In the two parts of the study, the aeration rate was controlled through a flow meter, maintaining the dissolved oxygen (DO) concentration between 2.0-2.5 $\mathrm{mg} \mathrm{O}_{2} / \mathrm{L}$.

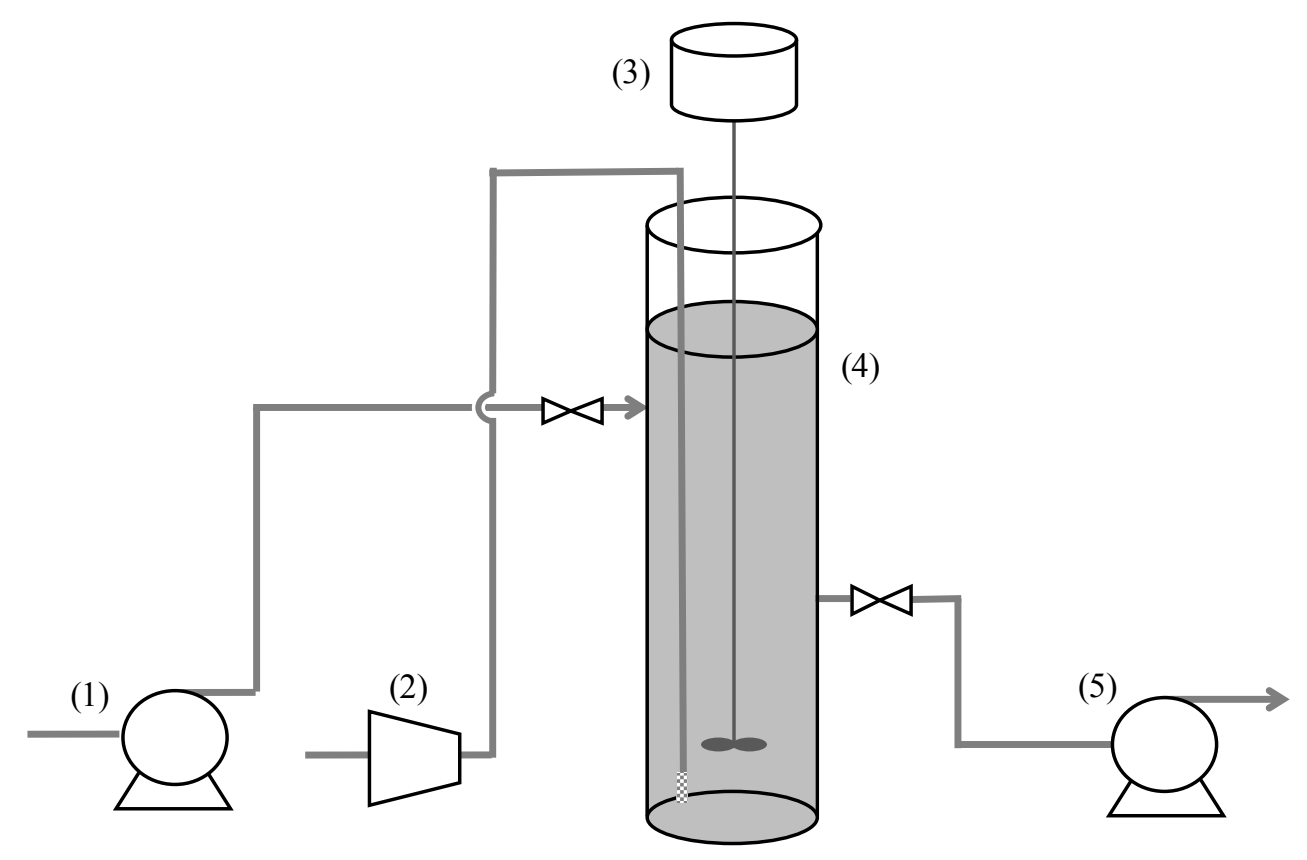

Figure 1. Scheme of the SBR plant. (1) Filling pump, supplies the wastewater from anaerobic treatment to the reactor, (2) Compressor, responsible for supplying the air for the aeration step, (3) Mechanical stirrer, (4) SBR reactor, (5) Pump that drains the water after treatment.

\subsection{Inoculum and Feeding Characteristics}

The inoculum of the three reactors studied was secondary aerobic sludge from the WWTP of Valladolid (Spain).

The reactors were fed with the effluent from an anaerobic membrane bioreactor (AnMBR) fed with raw domestic wastewater from the city of Valladolid (Spain). The AnMBR pilot plant is 
explained in detail in a previous work ${ }^{[20]}$. The mean concentration of the main parameters of the influent feeding the denitrification/nitrification plant are given in Table 1. It is a residual water with a high content in ammoniacal nitrogen and a low concentration of organic matter, leading to a COD/TN ratio as low as 1.2. In the inlet stream (from anaerobic treatment), sulfur is the corresponding amount of sulfide oxidation without quantify the oversaturation, so the real value for sulfide is higher.

Table 1: Average composition of the wastewater after anaerobic treatment.

\begin{tabular}{ccccccc}
$\begin{array}{c}\mathrm{sCOD} \\
\left(\mathrm{mg} \mathrm{O}_{2} / \mathrm{L}\right)\end{array}$ & $\begin{array}{c}\mathrm{TKN} \\
(\mathrm{mg} \mathrm{N} / \mathrm{L})\end{array}$ & $\begin{array}{c}\mathrm{NH}_{4}{ }^{+} \\
(\mathrm{mg} \mathrm{N} / \mathrm{L})\end{array}$ & $\begin{array}{c}\mathrm{NO}_{2}{ }^{-} \\
(\mathrm{mg} \mathrm{N} / \mathrm{L})\end{array}$ & $\begin{array}{c}\mathrm{NO}_{3}{ }^{-} \\
(\mathrm{mg} \mathrm{N} / \mathrm{L})\end{array}$ & $\begin{array}{c}\mathrm{SO}_{4}{ }^{2-} \\
(\mathrm{mg} \mathrm{S} / \mathrm{L})\end{array}$ & $\begin{array}{c}\text { sol P } \\
(\mathrm{mg} \mathrm{P} / \mathrm{L})\end{array}$ \\
\hline 100.6 & 81.9 & 77.7 & 0.0 & 0.0 & 8.5 & 9.2
\end{tabular}

\subsection{Analytical Methods}

Samples of wastewater were taken before and at the end of each treatment cycle. The concentration of nitrite, nitrate, sulfate and soluble phosphorus were measured by HPLC. The ammonium concentration was determined using an ammonia-selective electrode: Orion, model 9512HPBNWP. The analyses of COD, TKN as well as total and volatile suspended solids (TSS, VSS) were determined according to standard methods suggested by the Standard methods manual ${ }^{[21]}$. Temperature was measured using a temperature probe. The measurement of dissolved oxygen (DO) concentration was determined with an oximeter WTW, model oxi 330/SET and a dissolved oxygen probe CeliOx 325.

\subsection{Operation Strategy}

In the first part of the study (Section 3.1), before starting with the SBR system, the aeration period was optimized to ensure the nitrification process. To do so, two reactors with a total volume of $1 \mathrm{~L}$ were used. One reactor was aerated during $12 \mathrm{~h}$ and the other during $7 \mathrm{~h}$. These time was considered more than enough to oxidize the ammonium present in the wastewater.

For the rest of the work, the denitrifying/nitrifying SBR was used and operated with successive cycles. Each cycle consisted of 15 min of feeding stage, a reaction period, and finally, the supernatant draw was discharged during the last $15 \mathrm{~min}$, after $30 \mathrm{~min}$ of biomass settling. For the operation cycles determination, the cycles were initiated (after the filling) with an aerated stage and continued with an anoxic one (Sections 3.2 and 3.3). During the aeration phase, the average DO was between $2-2.5 \mathrm{mg} \mathrm{O} / \mathrm{L}$. In the discharge stage, $3.5 \mathrm{~L}$ of the total 
working volume were discharged, remaining in the reactor $1.5 \mathrm{~L}$, to be treated in the following cycle. The different cycles studied are presented in the Table 2.

Table 2: Time distribution of the stages of the different cycles.

\begin{tabular}{c|ccccc} 
Stage & Case 1 & Case 2 & Case 3 & Case 4 & Case 5 \\
\hline Filling & $15 \mathrm{~m}$ & $15 \mathrm{~m}$ & $15 \mathrm{~m}$ & $15 \mathrm{~m}$ & $15 \mathrm{~m}$ \\
Pre-anoxic & - & - & - & - & $30 \mathrm{~m}$ \\
Aeration & $7 \mathrm{~h}$ & $3 \mathrm{~h}$ & $5 \mathrm{~h} \mathrm{30 \textrm {m }}$ & $4 \mathrm{~h}$ & $3 \mathrm{~h} 45 \mathrm{~m}$ \\
Anoxic & $4 \mathrm{~h}$ & $4 \mathrm{~h}$ & $1 \mathrm{~h} \mathrm{30}$ & $1 \mathrm{~h}$ & $45 \mathrm{~m}$ \\
Sedimentation & $30 \mathrm{~m}$ & $30 \mathrm{~m}$ & $30 \mathrm{~m}$ & $30 \mathrm{~m}$ & $30 \mathrm{~m}$ \\
\hline Discharge & $15 \mathrm{~m}$ & $15 \mathrm{~m}$ & $15 \mathrm{~m}$ & $15 \mathrm{~m}$ & $15 \mathrm{~m}$ \\
\hline Cycle time: & 12 hours & 8 hours & 8 hours & 6 hours & $6 \mathrm{hours}$
\end{tabular}

Modifications of the cycle took place to enhance the organic matter and nitrogen removal efficiencies. In Case 5 (Section 3.4), a pre-anoxic stage was added and the cycles consisted of an anoxic stage, aeration stage and another anoxic stage. Finally, a new cycle was achieved by adding methanol before the last anoxic stage, to provide more organic matter to the denitrification step and in this way, enhance the reactions in this stage (Section 3.5).

\section{RESULTS AND DISCUSSION}

\subsection{Optimization of the aeration period.}

The required time to assure the nitrification process was study. In the Figure 2 , it can be seen the evolution of the nitrogen species during the aeration period of 7 and 12 hours. In the Figure $2 \mathrm{~A}$, where it is represented the TKN concentration in time, it can be seen the average values in the feed of 90 and $115 \mathrm{mg} \mathrm{N} / \mathrm{L}$ while in the effluent it was in the range of $20 \mathrm{mg} \mathrm{N} / \mathrm{L}$. During the first two hours of aeration, around $60 \%$ and $70 \%$ of the TKN concentration was decreased for the two cases studied, and the final TKN removal efficiency was about $79.4 \%$. In aerobic conditions ammoniacal nitrogen was nitrified, i.e. it was used as the energy source by nitrifying bacteria leading to the formation of nitrite and nitrate. Residual ammonium was utilized as the nitrogen source for the biomass synthesis by the bacteria. At the same time that ammonium was oxidized, nitrite and nitrate concentrations increased, although the latter more slowly, 3.5 hours vs 5 hours (Figure 2B). Nitrate and nitrite co-existed in the reactor, but having an accumulation of nitrite almost four times higher than nitrate. Nitrite was the primary 
product of nitrification during the aeration experiment, which was accumulated up to $63 \mathrm{mg}$ $\mathrm{NO}_{2}{ }^{-} \mathrm{N} / \mathrm{L}$, while the nitrate concentration was always below $15 \mathrm{mg} \mathrm{NO}{ }^{-} \mathrm{-N} / \mathrm{L}$. A higher level of nitrite accumulation indicates a high activity of $A O B$, suggesting that the partial nitrification performance of the aeration process was good. By contrast, the activity of NOB was limited in the aerobic phase. High nitrite accumulation has been reported by ${ }^{[19,22,23]}$ in SBR systems.

The optimum time considered for the aeration process was four hours. After four hours of aeration, the effluent showed a mean concentration of $15.0 \mathrm{mg} \mathrm{NH}_{4}{ }^{+} / \mathrm{L}, 58.5 \mathrm{mg} \mathrm{NO}_{2}{ }^{-} \mathrm{N} / \mathrm{L}$ and $12.3 \mathrm{mg} \mathrm{NO}_{3}{ }^{-} \mathrm{N} / \mathrm{L}$. After this time, there were a variation in the parameters lower than $5 \%$.
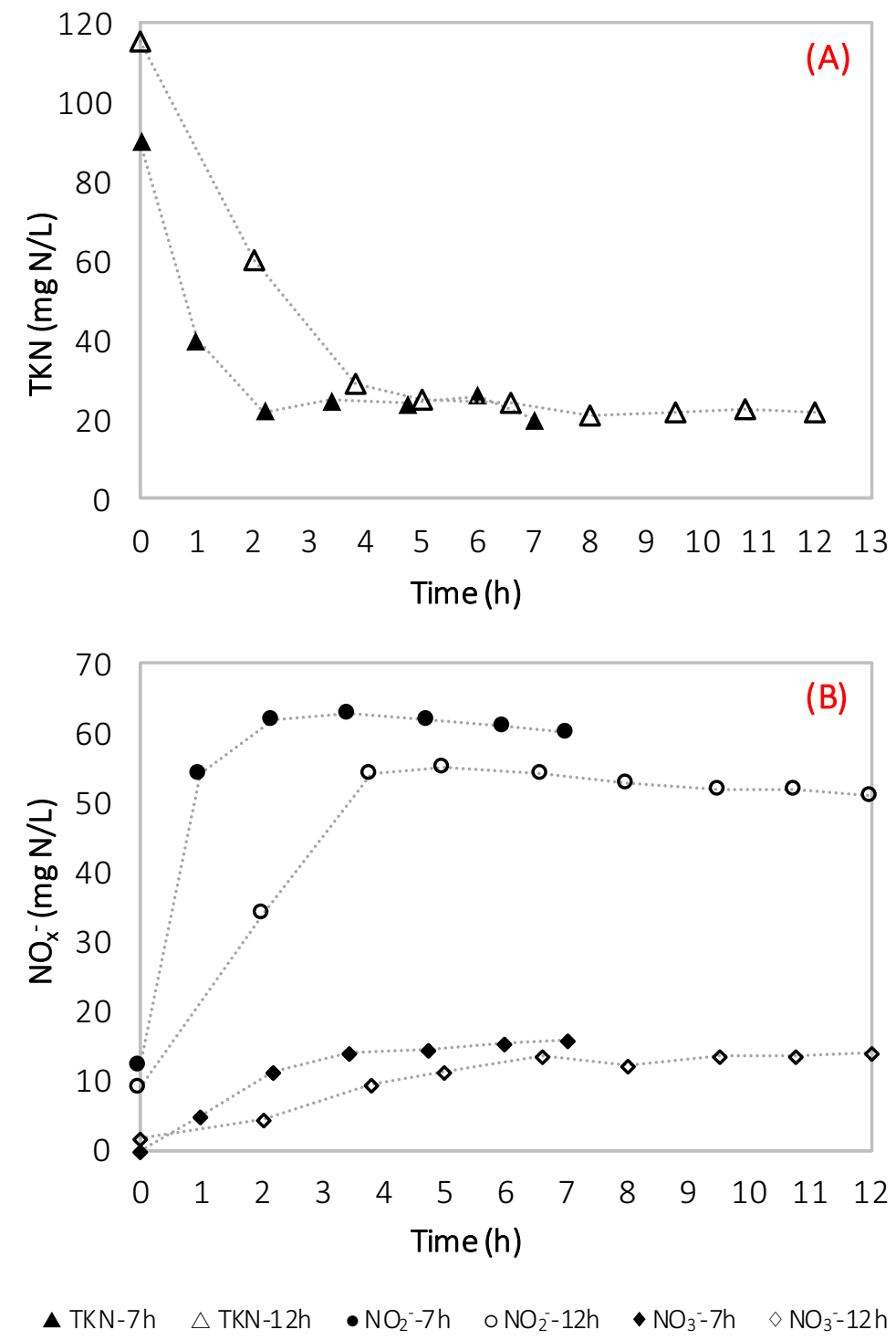

Figure 2. (A) Profile of TKN concentration during aeration; (B) Profile of nitrite and nitrate concentration during aeration. 


\subsection{Definition of the reactor operation cycles.}

The time of the aerobic and anoxic stages were changed with the aim of determining the influence of the duration of these stages in the nitrogen removal. Four cycles of $12 \mathrm{~h}$ (Case 1), 8 h (Cases 2-3) and 6 h (Case 4) were studied, as shown in Table 2.

Figure 3, (A) and (B) depict the graphic comparison in the $\mathrm{TKN}$ and $\mathrm{NO}_{2}{ }^{-}$, respectively, for the different cycles. Nitrate is not represented because only in the $12 \mathrm{~h}$ and $6 \mathrm{~h}$ cycles was detected but in very low amounts, not exceeding a concentration of $4 \mathrm{mg} \mathrm{NO}_{3}{ }^{-} \mathrm{N} / \mathrm{L}$.
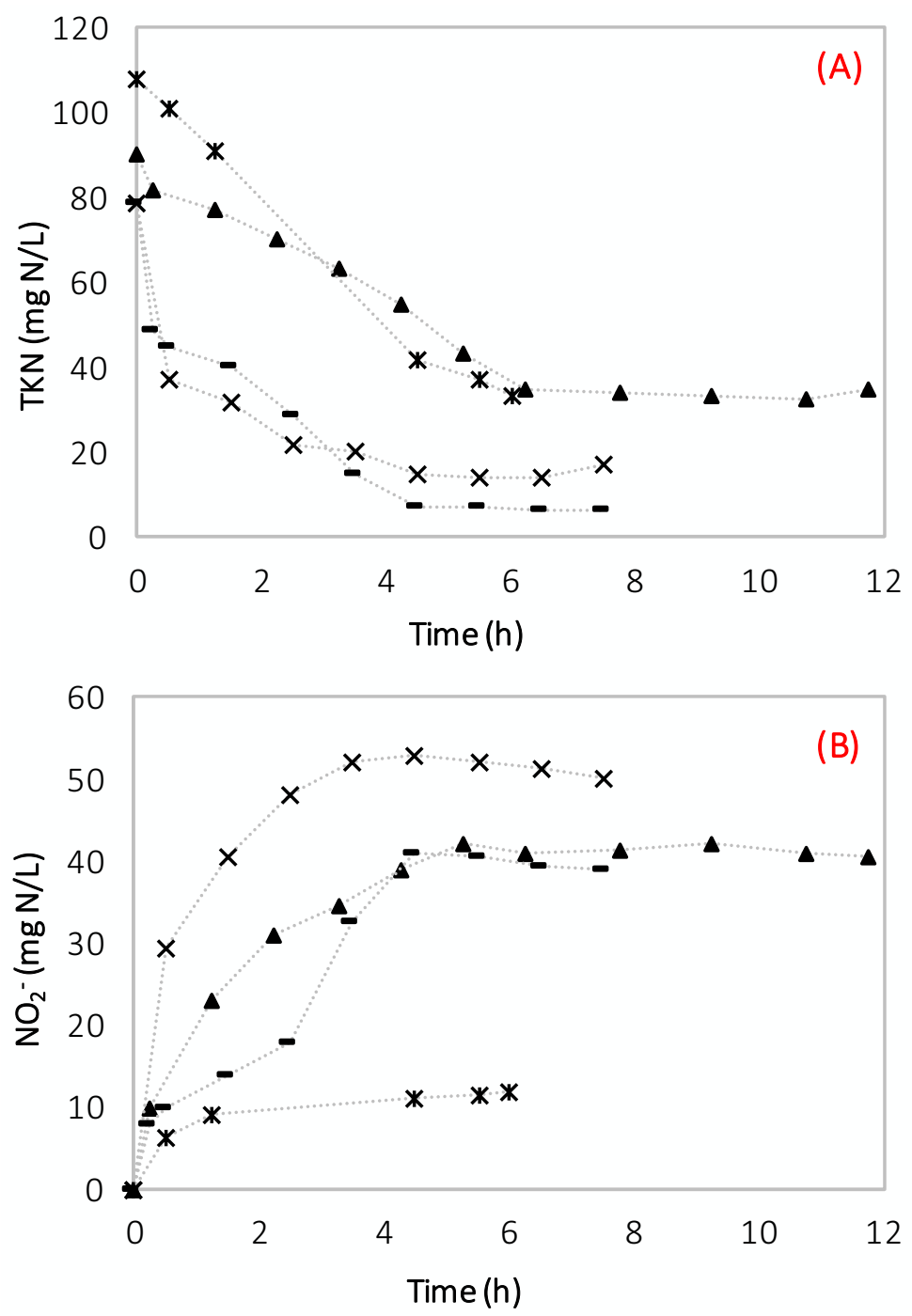

$\Delta$ Case 1 × Case 2 - Case 3 * Case 4

Figure 3. Profiles of TKN (A) and $\mathrm{NO}_{2}^{-}$(B) concentrations in time for the different cycles. 
In Figure 3A, can be observed that the average TKN concentration declined sharply during the first 6 hours. $\mathrm{NH}_{4}{ }^{+}$was almost completely oxidized in 6 hours. In cycles longer than 6 hours, TKN concentration decreased less than $4 \%$ from this time. Meanwhile, in Figure 3B, there was an increase in $\mathrm{NO}_{2}{ }^{-}$concentration achieving its maximum at around 4 hours of cycle and then, it remained constant or suffered a slight decline in its concentration.

Table 3 shows the nitrogen removal efficiencies for each cycle achieving the highest value, $54 \%$, in the last cycle. Therefore, it was considered the optimum cycle for nitrogen removal to have a duration of $6 \mathrm{~h}$.

Table 3: Nitrogen concentration in the wastewater before and after the SBR process in the different cycles.

\begin{tabular}{cc|cccc}
\multicolumn{2}{c|}{ Parameter } & Case 1 & Case 2 & Case 3 & Case 4 \\
\hline \multirow{2}{*}{$\begin{array}{c}\text { N inlet } \\
\text { (mg N/L) }\end{array}$} & $\mathrm{NKN}_{2}^{-}$ & 90.0 & 78.8 & 78.8 & 107.5 \\
& $\mathrm{NO}_{3}^{-}$ & 0.0 & 0.0 & 0.0 & 0.0 \\
\hline \multirow{2}{*}{$\mathrm{N}$ outlet } & $\mathrm{TKN}^{-}$ & 32.1 & 17.1 & 6.4 & 33.3 \\
(mg N/L) & $\mathrm{NO}_{2}^{-}$ & 40.4 & 50.0 & 37.7 & 11.9 \\
& $\mathrm{NO}_{3}^{-}$ & 2.4 & 0.0 & 0.0 & 4.3 \\
\hline \multicolumn{2}{c}{$\%$ TN removed: } & $16.8 \%$ & $14.3 \%$ & $44.0 \%$ & $54.0 \%$
\end{tabular}

\subsection{Study of a $6 \mathrm{~h}$ cycle.}

The SBR process with a $6 \mathrm{~h}$ cycle was studied during 70 days.

Figures 4 to 6 show the evolution of the soluble COD, TKN, $\mathrm{NO}_{2}{ }^{-} \mathrm{N}$ and $\mathrm{NO}_{3}{ }^{-} \mathrm{N}$ concentrations during the aerobic/anoxic cycle of the operational period in the SBR. For the cases of COD and TKN can be seen that influent and effluent followed the same trend (Figures 4 and 5). The effluent concentrations increased when the inlet stream had a higher load, and decreased when lowering the influent concentration. The mean removal efficiencies of COD and TN were $30.3 \%$ and $42.9 \%$, respectively. These efficiencies were very low so it was necessary to consider a modification of the cycle. 


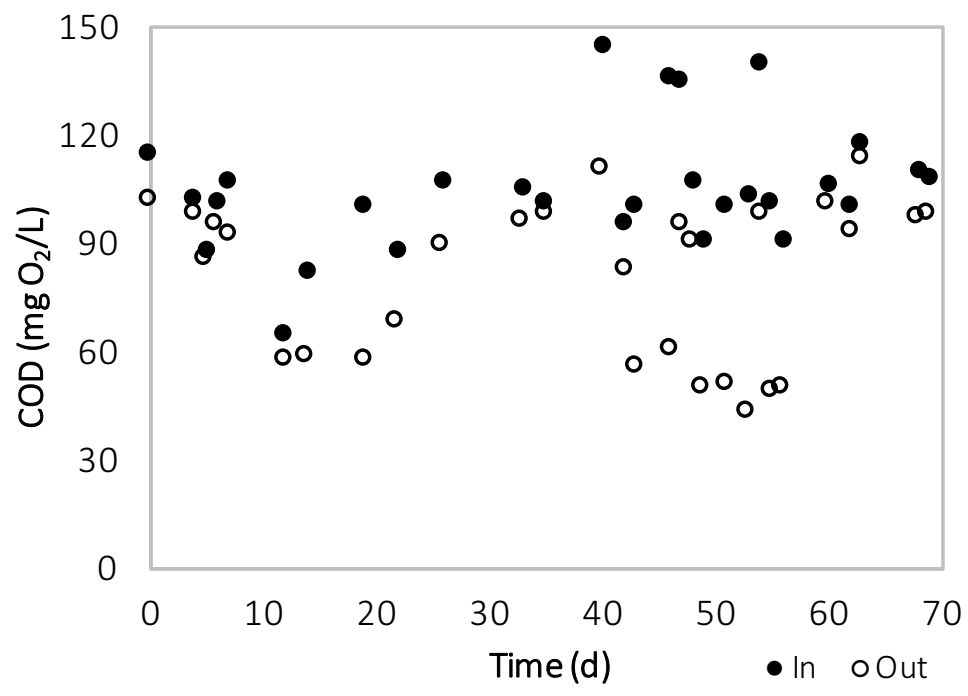

Figure 4. COD concentration in the influent and effluent in time, for the $6 \mathrm{~h}$ aerobic/anoxic cycle.

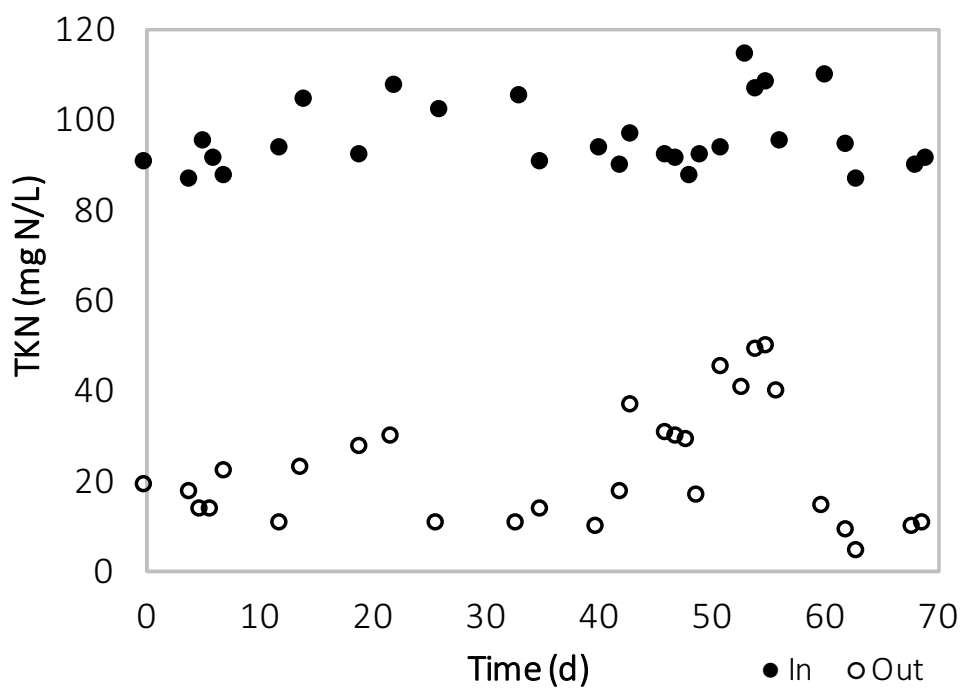

Figure 5. TKN concentration in the influent and effluent in time, for the $6 \mathrm{~h}$ aerobic/anoxic cycle. 

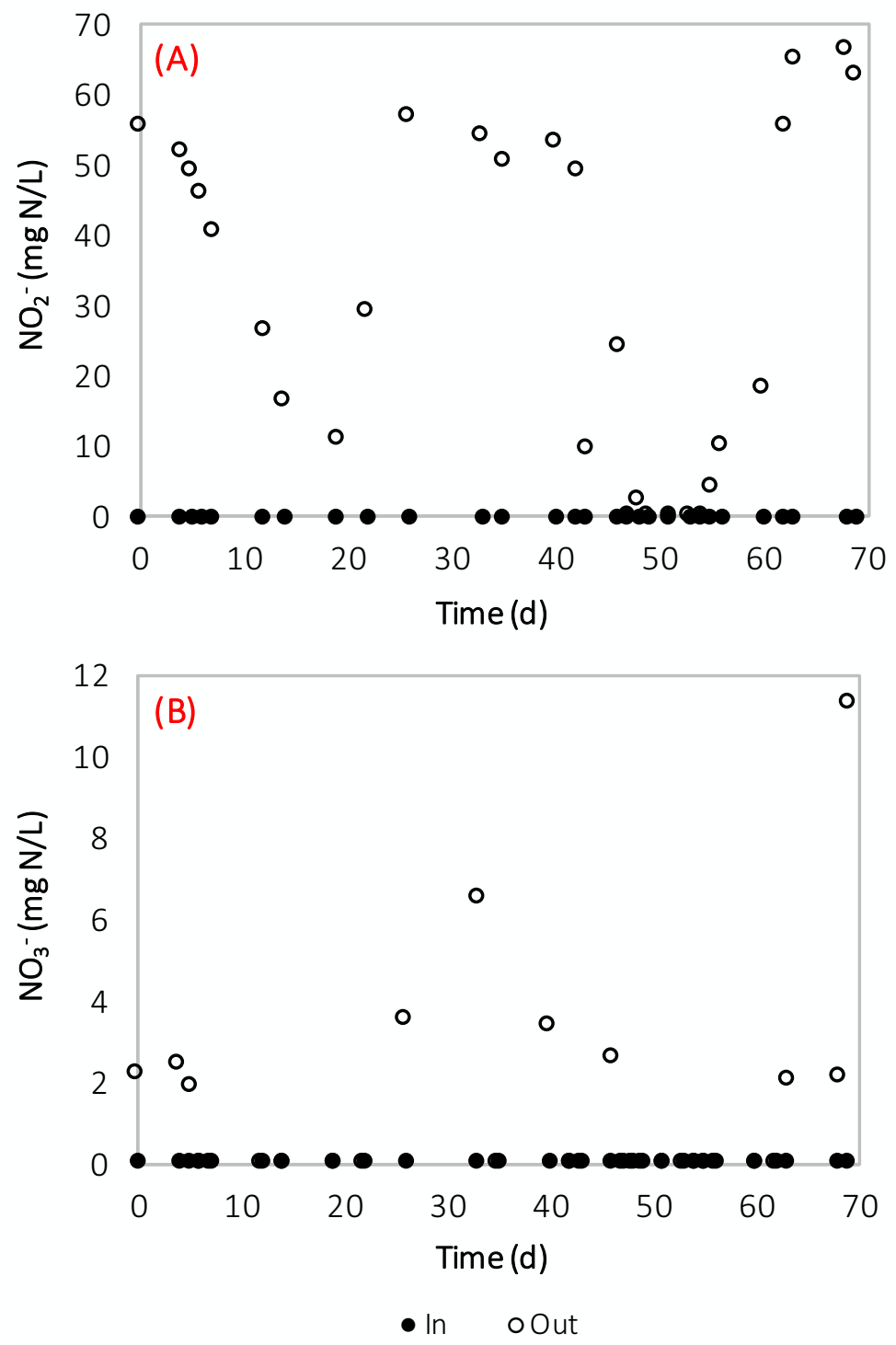

Figure 6. Nitrite (A) and nitrate (B) concentration in the influent and effluent in time, for the $6 \mathrm{~h}$ aerobic/anoxic cycle.

During most of the time, the final effluent exhibited a high nitrite concentration that proceed from a low-yield denitrification process (Figure 6A). As said before, during the aeration stage, there was nitrite accumulation in the tank because mainly, partial nitrification took place. Therefore, a low denitrification yield was observed due to the low organic matter available in the wastewater after the anaerobic treatment. The $\mathrm{C} / \mathrm{N}$ ratio of 1.2 was low for establish an efficient denitrification process. Concerning the nitrate, throughout the study period, it has been an absence of this compound, except in very few specific cases (Figure 6B).

Soluble phosphorus concentration did not suffer considerable changes with the SBR process (Figure 7). A slight removal of about $12 \%$ was observed. 


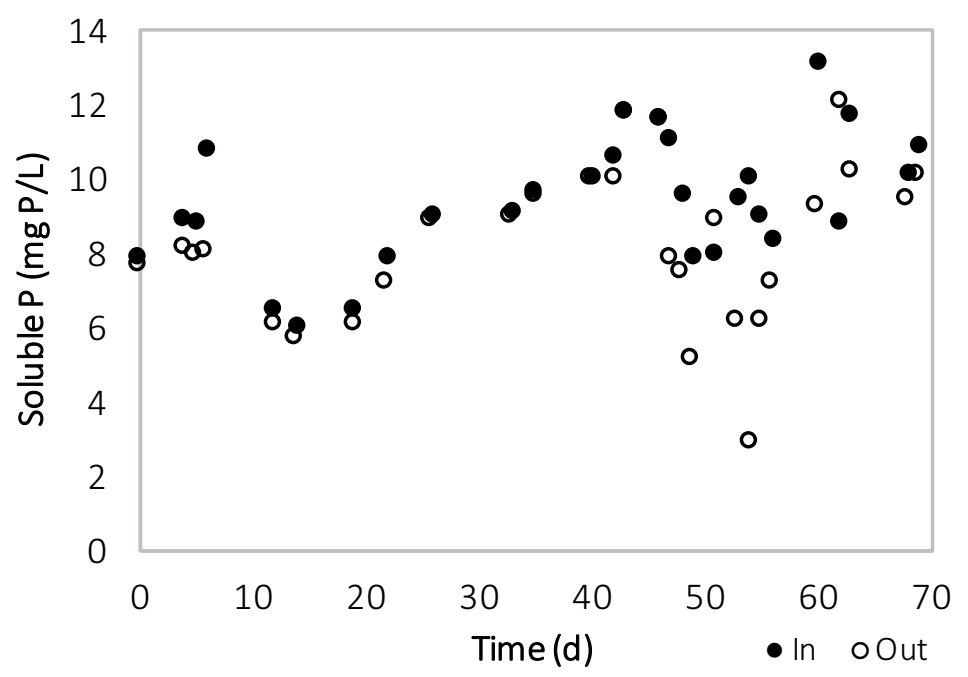

Figure 7. Soluble phosphorus concentration in the influent and effluent in time, for the $6 \mathrm{~h}$ aerobic/anoxic cycle.

\subsection{Addition of a pre-anoxic stage.}

In order to improve the denitrification process, a pre-denitrification stage was added in the cycle, prior to the aeration step. Thus, during the first anoxic stage of 30 minutes, residual nitrite and nitrate not eliminated in the previous cycle, that remains in the $1.5 \mathrm{~L}$ not discharged, could be reduced to nitrogen $\mathrm{N}_{2}$.

Having two anoxic stages allows lowering the TKN effluent concentrations. Thus, most of the nitrites and nitrates produced after nitrification in the aeration stage can be treated by flowing through the second anoxic stage. Pre-anoxic stage has been used with beneficial results to accomplish the removal of organic matter and nitrogen by Lu, Q. et al. ${ }^{[24]}$.

To adapt the cycle to this new change, it was necessary to modify the times of the different periods, so that the six-hour cycle was carried out as indicates the Case 5 in Table 2. The parameters concentration before and after SBR treatment for the modified cycle are shown in the Table 4.

Table 4. Parameters concentration before and after 6 hours modified cycle treatment.

\begin{tabular}{c|cccccc} 
& $\begin{array}{c}\mathrm{sCOD} \\
\left(\mathrm{mg} \mathrm{O}_{2} / \mathrm{L}\right)\end{array}$ & $\begin{array}{c}\mathrm{TKN} \\
(\mathrm{mg} \mathrm{N} / \mathrm{L})\end{array}$ & $\begin{array}{c}\mathrm{NH}_{4}^{+} \\
\left(\mathrm{mg} \mathrm{N}^{+} \mathrm{L}\right)\end{array}$ & $\begin{array}{c}\mathrm{NO}_{2}^{-} \\
\left(\mathrm{mg} \mathrm{N}^{-} \mathrm{L}\right)\end{array}$ & $\begin{array}{c}\mathrm{NO}_{3}^{-} \\
(\mathrm{mg} \mathrm{N} / \mathrm{L})\end{array}$ & $\begin{array}{c}\text { sol P } \\
(\mathrm{mg} \mathrm{P} / \mathrm{L})\end{array}$ \\
\hline Influent & 111.3 & 99.5 & 88.4 & 0.0 & 0.0 & 12.3 \\
Effluent & 67.9 & 20.2 & 18.1 & 25.3 & 1.5 & 12.6
\end{tabular}

Almost the $80 \%$ of TKN was removed in the denitrification/nitrification process, resulting a final effluent with a concentration of around $20.2 \mathrm{mg} \mathrm{N} / \mathrm{L}$. During the first anoxic stage, $\mathrm{NO}_{2}{ }^{-}$ and $\mathrm{NO}_{3}{ }^{-}$from the previous cycle was removed. During the aeration stage, $\mathrm{NH}_{4}{ }^{+}$was decreased 
from 88.4 to $18.1 \mathrm{mg} \mathrm{N} / \mathrm{L}$ under the supply of DO, whereas there was a corresponding increase of $\mathrm{NO}_{2}{ }^{-}$concentration. In the following anoxic phase, $\mathrm{NO}_{2}{ }^{-}$concentration decreased to $25.3 \mathrm{mg}$ $\mathrm{NO}_{2}{ }^{-} \mathrm{N} / \mathrm{L}$. Nitrite was the primary product of the process, showing an accumulation, while the nitrate concentration was always very low, about $1.5 \mathrm{mg} \mathrm{NO}_{3}{ }^{-} \mathrm{N} / \mathrm{L}$. The removal efficiencies of COD and TN were $39.0 \%$ and 52.8\%, respectively, resulting in efficiencies improvement of about $20 \%$ when comparing the cycle without pre-anoxic stage.

\subsection{Addition of methanol}

The anoxic/oxic/anoxic process requires sufficient degradable carbon substrate to provide the energy source needed for the denitrification reactions that occurs after the aeration stage. Due to the low amount of easily biodegradable organic matter available in the wastewater to be treated in the SBR process, methanol was added as an external carbon source before the denitrification stage ${ }^{[25-27]}$. This compound could be used as electron donor by the denitrifying bacteria, responsible of the nitrate and nitrite reducing to gaseous nitrogen. A solution of methanol (1:100) was added in the cycle before the second anoxic stage, just after finish the aeration.

It is noteworthy that instead of the addition of methanol, the increase of organic matter in WWTPs can be made by bypassing part of the feedstream from a point before the anaerobic treatment to another point in the end of this reactor. With this course of action, it is possible to increase the soluble COD available in the liquid stream that feeds the denitrification reactor, without adding an external carbon source. In this work, in order to simulate this behavior, the addition of methanol was employed as extra carbon source.

The COD, TKN, $\mathrm{NO}_{2}{ }^{-}$and $\mathrm{NO}_{3}{ }^{-}$graphics correspond to the Figures 8 to 10 , respectively. This part of the study had a duration of three months and has been divided in three stages as indicates Table 5.

Tabla 5: Summary of the stages. (COD AnMBR: COD of the AnMBR effluent. COD Methanol: COD supplied with methanol. COD inlet: COD of the SBR feed).

\begin{tabular}{c|cccccccc} 
Stage & Days & COD AnMBR & COD Methanol & COD inlet & TN & C/N & \%TN removed & \%COD removed \\
\hline 1 & $0-20$ & 195,6 & 0,0 & 195,6 & 93,0 & 2,1 & $40,7 \%$ & $53,7 \%$ \\
2 & $21-70$ & 148,6 & 81,9 & 230,6 & 97,4 & 2,4 & $74,7 \%$ & $57,8 \%$ \\
3 & $71-91$ & 176,2 & 97,1 & 273,3 & 90,6 & 3,0 & $83,9 \%$ & $76,7 \%$
\end{tabular}

Until day 20, the COD in the wastewater from anaerobic treatment was approximately 196 $\mathrm{mg} \mathrm{O}_{2} / \mathrm{L}$ and methanol was not added to evaluate the reactor's reaction. In this period, the $\mathrm{C} / \mathrm{N}$ ratio was 2. TKN was removed almost 90\%, obtaining a mean concentration of TKN of $9.6 \mathrm{mg}$ $\mathrm{N} / \mathrm{L}$ in the effluent. The nitrite and nitrate raised until concentrations of $41 \mathrm{mg} \mathrm{NO}_{2}^{-}-\mathrm{N} / \mathrm{L}$ and 37 
mg NO${ }_{3}{ }^{-} \mathrm{N} / \mathrm{L}$. The COD and TN efficiencies decreased to $53.7 \%$ and $40.7 \%$, respectively, because of the lower $\mathrm{C} / \mathrm{N}$ ratio.

From day 21 to 70 , methanol was added up to $231 \mathrm{mg} \mathrm{O} / \mathrm{L}$. The $\mathrm{C} / \mathrm{N}$ ratio was 2.4 . Approximately, $86 \%$ of TKN was removed, obtaining an effluent with a mean concentration of TKN of $13.3 \mathrm{mg} \mathrm{N} / \mathrm{L}$. Nitrite was found in the effluent during this period, with a concentration about $10.6 \mathrm{mg} \mathrm{NO}{ }_{2}^{-}-\mathrm{N} / \mathrm{L}$, achieving $19 \mathrm{mg} \mathrm{NO}_{2}{ }^{-} \mathrm{N} / \mathrm{L}$ in a point. It is noteworthy the effect of the addition of methanol in nitrate but mainly in nitrite (Figure 10). These compounds suffered a significant decrease in their concentrations when the COD was increased. The removal efficiencies of COD and TN raised up to $57.8 \%$ and $74.7 \%$, respectively.

Finally, from day 71 to 91 , a COD of about $273 \mathrm{mg}$ O2/L was achieved with the addition of methanol. The $\mathrm{C} / \mathrm{N}$ ratio was 3 . Up to $97.7 \%$ of TKN was removed in this section, obtaining a mean concentration of TKN of $2.1 \mathrm{mg} \mathrm{N} / \mathrm{L}$ in the effluent. The nitrite concentration in the effluent was about $11.4 \mathrm{mg} \mathrm{NO}{ }^{-}-\mathrm{N} / \mathrm{L}$. Removal efficiencies of COD and TN of $76.7 \%$ and $83.9 \%$, respectively, were obtained.

Instead of the methanol addition, bypassing a volumetric flow of $30 \%$ of the anaerobic feed from a point before the AnMBR to another point in the end of this reactor, is possible to increase the available soluble COD 55\% up to reach $273 \mathrm{mg} \mathrm{O} / \mathrm{L}$. Estimation based on the average of $501 \mathrm{mg} \mathrm{O}_{2} / \mathrm{L}$ of soluble COD that contains the wastewater before the anaerobic treatment, after the sedimentation stage ${ }^{[20]}$.

About $98 \%$ of TKN was removed in the last section of the study. At the end of the cycle, a mean concentration of TKN of $2.1 \mathrm{mg} \mathrm{N} / \mathrm{L}$ was obtained. About $91 \%$ of the ammoniacal nitrogen after the aerobic stage was nitrified and $7 \%$ was assimilated by heterotrophic bacteria. The effluent after the cycle contained around $11.4 \mathrm{mg} \mathrm{NO}_{2}^{-}-\mathrm{N} / \mathrm{L}$ while nitrates were occasionally found with a concentration of $2.5 \mathrm{mg} \mathrm{NO}_{3}{ }^{-} \mathrm{N} / \mathrm{L}$. Therefore, nitrite was the main compound accumulated in the reactor. After completion of the nitrification, about $79.7 \%$ and $92.2 \%$ of the generated nitrite and nitrate, respectively, were removed by denitrification.

The removal efficiencies of COD and TN with this cycle configuration were $76.7 \%$ and $83.9 \%$, respectively. After the SBR treatment, the effluent contained a mean TN concentration of 14.6 mg N/L. High removal percentages was observed. If these efficiencies are compared with the ones without methanol addition, there was an improvement of about $43 \%$ in COD removal and the TN removal yield was doubled. Theses increases in the organic matter and nitrogen removal were attributed to a higher denitrified activity in this cycle configuration. 


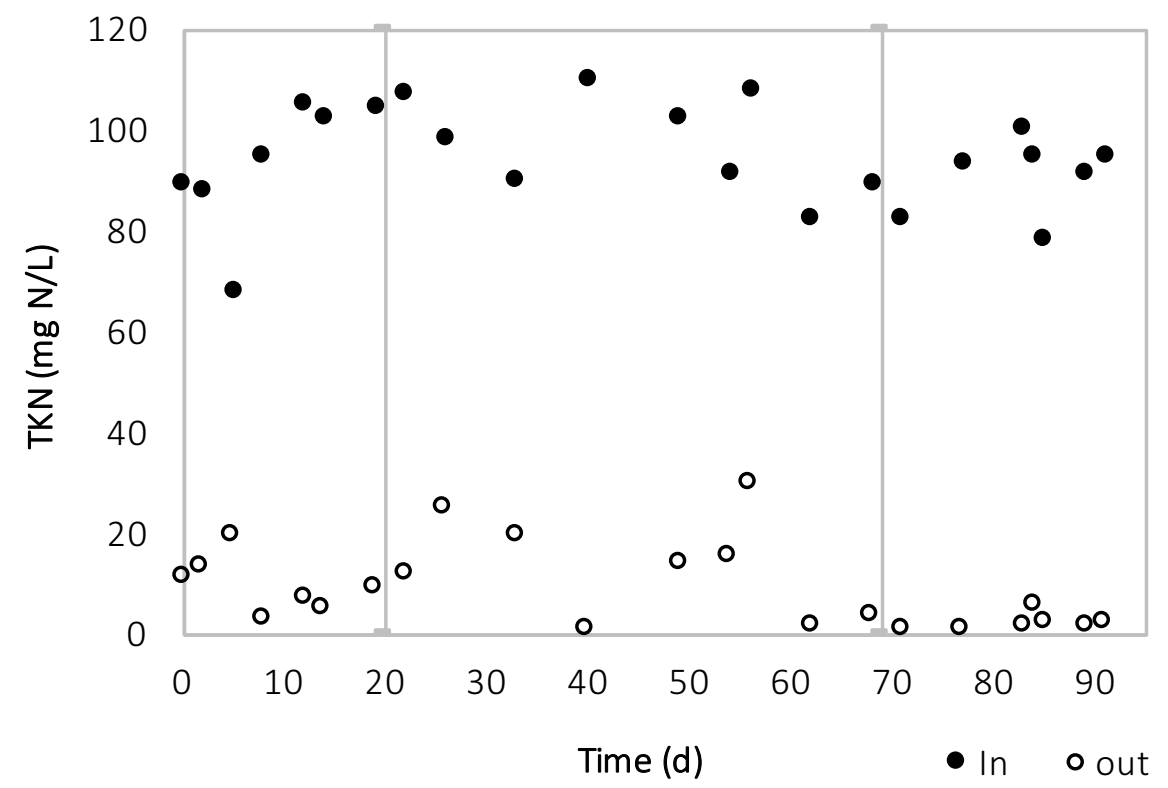

Figure 9. TKN concentration in the influent and effluent in time, for the $6 \mathrm{~h}$ anoxic/aerobic/anoxic cycle with addition of methanol.

Comparing to the literature, Hwang et al. ${ }^{[27]}$ reached $80 \%$ of nitrogen removal efficiency by using a sequencing batch biofilm reactor treating the rejected water from sludge. Its reactor temperature was 15-35 으. The reactor performed an aerobic-anoxic-aerobic-anoxic sequence and added methanol at the beginning of each anoxic step. The total cycle time used was $8 \mathrm{~h}$, versus $6 \mathrm{~h}$ in the present study. Therefore, that process needs two more hours per cycle to achieve the same nitrogen removal than the process developed here. In the same research, Hwang et al. enhanced the nitrogen removal efficiency up to $91 \%$ in a anoxic-aerobic-anoxic sequence when adding methanol as external carbon source and $\mathrm{NaHCO}_{3}$ as alkalinity, but with the same total cycle time of $8 \mathrm{~h}^{[27]}$.

On the other hand, Fernandes et al. ${ }^{[28]}$ used a SBR treating domestic wastewater with a $\mathrm{C} / \mathrm{N}$ ratio of 3. Although it operated with a cycle time of $8 \mathrm{~h}$ (versus $6 \mathrm{~h}$ in this study), its COD removal efficiency was higher: $83 \%$ versus $77 \%$ obtained in the present study. On the contrary, that process only achieved a mean of $50 \%$ of TN removal, versus $84 \%$ in the present study.

The SBR performed by Chen et al. ${ }^{[29]}$ was used for the bioaugmented treatment of municipal wastewater with a $\mathrm{C} / \mathrm{N}$ ratio of 8 , achieved with external carbon dosages. Comparing to the present study, Chen et al. achieved better COD removal efficiency, $85.2 \%$ versus $76.7 \%$ and $80.5 \%$ of $\mathrm{N}$ removal versus $84 \%$ in this study. Moreover, their system required much more amount of external carbon source to reach a $\mathrm{C} / \mathrm{N}$ ratio almost 3 times higher than the presented in this work $(\mathrm{C} / \mathrm{N}=8$ versus $\mathrm{C} / \mathrm{N}=3)$. 

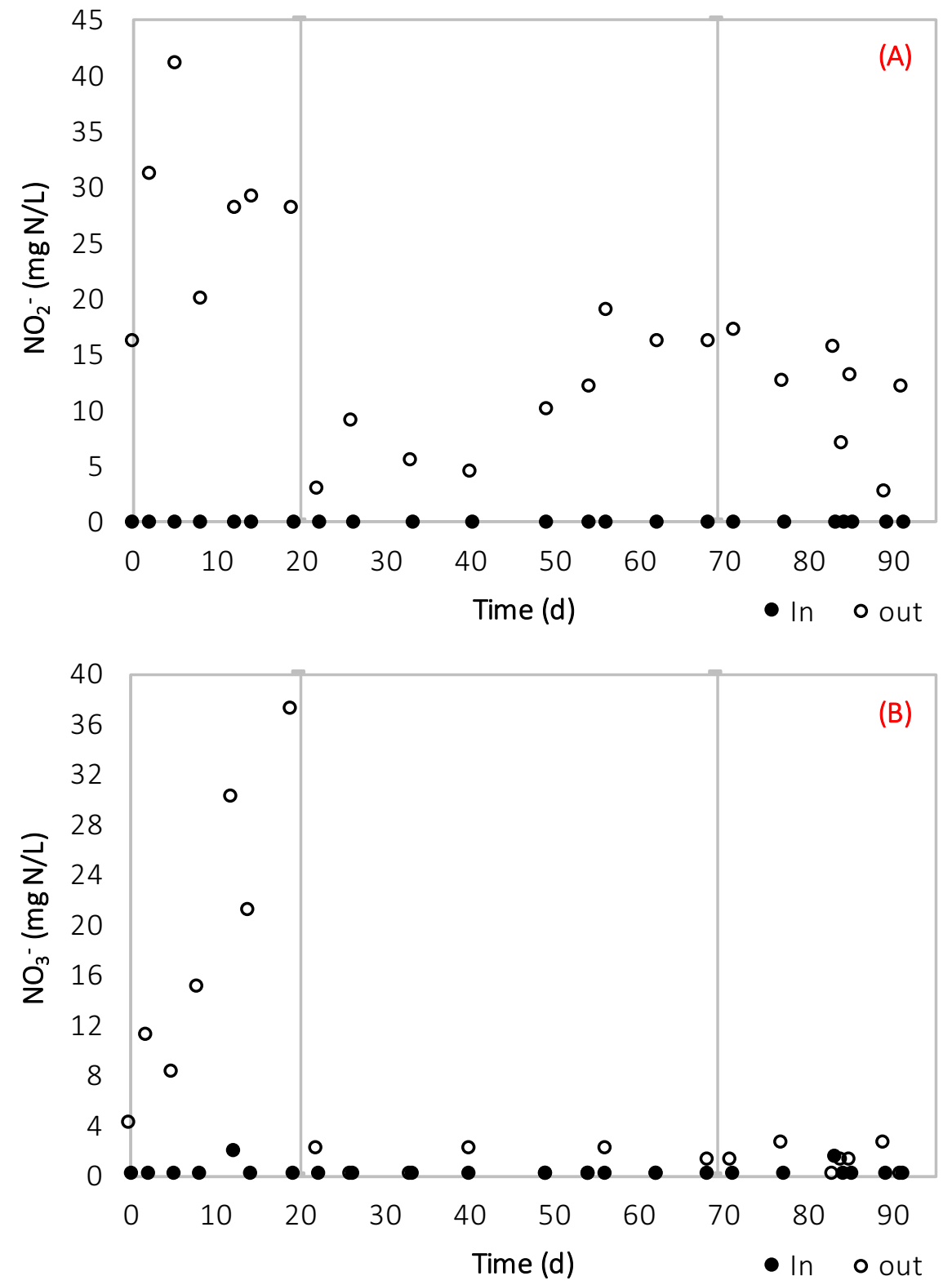

Figure 10. Nitrite (A) and nitrate (B) concentration in the influent and effluent in time, for the $6 \mathrm{~h}$ anoxic/aerobic/anoxic cycle with addition of methanol.

\section{CONCLUSIONS}

A SBR process was applied to a domestic wastewater from anaerobic treatment and therefore, with a low concentration of organic matter. An experimental study on a pilot plant scale was carried out to ascertain its suitability for simultaneous nitrification and denitrification. Cycle times of $12 \mathrm{~h}, 8 \mathrm{~h}$ and $6 \mathrm{~h}$ in SBR were considered in the study, and the $6 \mathrm{~h}$ cycle time was selected as the optimal for the treatment. Results from nitrification and denitrification of domestic wastewater in the SBR showed nitrogen and COD removal efficiencies of about $84 \%$ 
and $77 \%$, respectively. The process was successful in an anoxic/aerobic/anoxic cycle sequence with the addition of methanol just before the second anoxic stage. Thus, it has been demonstrated that the SBR process in a single reactor at low temperature is a suitable process for the simultaneous removal of nitrogen and organic matter of a domestic wastewater with Iow COD with only the addition of external carbon source. The addition of methanol was employed as a model for the wastewater by-pass in the WWTP. As future work it is proposed to evaluate the effect of increasing the carbon ratio on the nitrogen elimination potential using the mixing of the anaerobic reactor effluent and the raw feed.

\section{ACKNOWLEDGEMENTS}

The authors thank the company Cadagua S.A., the European Regional Development Fund, and the project IPT-2011-1078-310000, and the INNPACTO 2011 program of the Ministry of Economy and Competitiveness for the technical and financial support. 


\section{References}

1. V. V. Ranade and V. M. Bhandari, Industrial Wastewater Treatment, Recycling and Reuse, Elsevier Science, 2014.

2. M. Hatamoto, K. Ohtsuki, N. Maharjan, S. Ono, K. Dehama, K. Sakamoto, M. Takahashi and T. Yamaguchi, Performance evaluation of the sulfur-redox-reaction-activated upflow anaerobic sludge blanket and down-flow hanging sponge anaerobic/anoxic sequencing batch reactor system for municipal sewage treatment, Bioresource Technology, 2016, 204171 - 176.

3. A. Moawad, U. F. Mahmoud, M. A. El-Khateeb and E. El-Molla, Coupling of sequencing batch reactor and UASB reactor for domestic wastewater treatment, Desalination, 2009, 242(1-3), p.325 - 335.

4. J. D. Vela, L. B. Stadler, K. J. Martin, L. Raskin, C. B. Bott and N. G. Love, Prospects for Biological Nitrogen Removal from Anaerobic Effluents during Mainstream Wastewater Treatment, Environmental Science \& Technology Letters, 2015, 2(9), p.234-244.

5. K. Abid Ali, G. Rubia Zahid, K. Absar Ahmad and L. Beni, in Biodegradation - Engineering and Technology, 2013.

6. Y. J. Chan, M. F. Chong, C. L. Law and D. G. Hassell, A review on anaerobic-aerobic treatment of industrial and municipal wastewater, Chemical Engineering Journal, 2009, 155(1-2), p.1-18.

7. Y. Liu, X. Su, L. Lu, L. Ding and C. Shen, A novel approach to enhance biological nutrient removal using a culture supernatant from Micrococcus luteus containing resuscitationpromoting factor (Rpf) in SBR process, Environmental Science and Pollution Research, 2015, 23(5), p.4498-4508.

8. G. Liu, X. Xu, L. Zhu, S. Xing and J. Chen, Biological nutrient removal in a continuous anaerobic-aerobic-anoxic process treating synthetic domestic wastewater, Chemical Engineering Journal, 2013, 225223 - 229.

9. H. Sun, H. Zhao, B. Bai, Y. Chen, Q. Yang and Y. Peng, Advanced removal of organic and nitrogen from ammonium-rich landfill leachate using an anaerobic-aerobic system, Chinese Journal of Chemical Engineering, 2015, 23(6), p.1047 - 1051.

10. J. C. A. Marin, A. H. Caravelli and N. E. Zaritzky, Nitrification and aerobic denitrification in anoxic-aerobic sequencing batch reactor, Bioresource Technology, 2016, 200380 - 387.

11. R. Blackburne, Z. Yuan and J. Keller, Demonstration of nitrogen removal via nitrite in a sequencing batch reactor treating domestic wastewater, Water Research, 2008, 42(89), p.2166 - 2176. 
12. R. N. Mohammed, S. Abu-Alhail and L. Xi-wu, Long-term operation of a novel pilot-scale six tanks alternately operating activated sludge process in treating domestic wastewater, Environmental Technology, 2014, 35(15), p.1874-1885.

13. A. Al-Omari, B. Wett, I. Nopens, H. De Clippeleir, M. Han, P. Regmi, C. Bott and S. Murthy, Model-based evaluation of mechanisms and benefits of mainstream shortcut nitrogen removal processes, Water Science and Technology, 2015, 71(6), p.840-847.

14. M. A. Fulazzaky, N. H. Abdullah, A. R. Mohd Yusoff and E. Paul, Conditioning the alternating aerobic-anoxic process to enhance the removal of inorganic nitrogen pollution from a municipal wastewater in France, Journal of Cleaner Production, 2015, 100195-201.

15. T. V. K. Mohan, Y. V. Nancharaiah, V. P. Venugopalan and P. M. S. Sai, Effect of C/N ratio on denitrification of high-strength nitrate wastewater in anoxic granular sludge sequencing batch reactors, Ecological Engineering, 2016, 91441 - 448.

16. C. Cherchi, A. Onnis-Hayden, I. El-Shawabkeh and A. Z. Gu, Implication of using different carbon sources for denitrification in wastewater treatments, Water Environment Research, 2009, 81(8), p.788-799.

17. C. A. L. Chernicharo, Post-treatment options for the anaerobic treatment of domestic wastewater, Reviews in Environmental Science and Biotechnology, 2006, 5(1), p.73-92.

18. C. A. L. Chernicharo, J. B. van Lier, A. Noyola and T. Bressani Ribeiro, Anaerobic sewage treatment: state of the art, constraints and challenges, Reviews in Environmental Science and Bio/Technology, 2015, 14(4), p.649-679.

19. Z. She, L. Zhao, X. Zhang, C. Jin, L. Guo, S. Yang, Y. Zhao and M. Gao, Partial nitrification and denitrification in a sequencing batch reactor treating high-salinity wastewater, Chemical Engineering Journal, 2016, 288207 - 215.

20. J. Gouveia, F. Plaza, G. Garralon, F. Fdz-Polanco and M. Peña, Long-term operation of a pilot scale anaerobic membrane bioreactor (AnMBR) for the treatment of municipal wastewater under psychrophilic conditions, Bioresource Technology, 2015, 185225 233.

21. Apha, Standard Methods for the Examination of Water and Wastewater, American Public Health Association, Washington D.C., USA, 1998.

22. S. Aslan, L. Miller and M. Dahab, Ammonium oxidation via nitrite accumulation under limited oxygen concentration in sequencing batch reactors, Bioresource Technology, 2009, 100(2), p.659 - 664. 
23. D. Wei, L. Shi, G. Zhang, Y. Wang, S. Shi, Q. Wei and B. Du, Comparison of nitrous oxide emissions in partial nitrifying and full nitrifying granular sludge reactors treating ammonium-rich wastewater, Bioresource Technology, 2014, 171487 - 490.

24. Q. Lu, R. A. d. Toledo and H. Shim, Effect of COD/TP ratio on biological nutrient removal in A2O and SBR processes coupled with microfiltration and effluent reuse potential, Environmental Technology, 2016, 37(12), p.1461-1466.

25. C. Wu, Z. Chen, X. Liu and Y. Peng, Nitrification-denitrification via nitrite in SBR using real-time control strategy when treating domestic wastewater, Biochemical Engineering Journal, 2007, 36(2), p.87 - 92.

26. M. P. Ginige, J. C. Bowyer, L. Foley, J. Keller and Z. Yuan, A comparative study of methanol as a supplementary carbon source for enhancing denitrification in primary and secondary anoxic zones, Biodegradation, 2008, 20(2), p.221-234.

27. B. Hwang, Q. Lu, R. A. d. Toledo and H. Shim, Enhanced nitrogen removal from sludge reject water by methanol addition using sequencing batch biofilm reactor, Desalination and Water Treatment, 2016, 57(19), p.8730-8738.

28. H. Fernandes, M. K. Jungles, H. Hoffmann, R. V. Antonio and R. H. R. Costa, Full-scale sequencing batch reactor (SBR) for domestic wastewater: Performance and diversity of microbial communities, Bioresource Technology, 2013, 132262 - 268.

29. Q. Chen, J. Ni, T. Ma, T. Liu and M. Zheng, Bioaugmentation treatment of municipal wastewater with heterotrophic-aerobic nitrogen removal bacteria in a pilot-scale SBR, Bioresource Technology, 2015, 18325 - 32. 


\title{
Chapter 3. Denitrification of the AnMBR effluent with alternative electron donors in domestic wastewater treatment
}

\begin{abstract}
The performance of a fixed film bioreactor for partial and total denitrification of the effluent from an anaerobic membrane bioreactor ( $A n M B R$ ) treating domestic water was investigated. Wastewater after anaerobic treatment, with a low $\mathrm{C} / \mathrm{N}$ ratio, contains a remaining chemical oxygen demand (COD) which is not enough for the conventional heterotrophic denitrification. As the effluent from the lowtemperature anaerobic reactor holds methane and sulfide dissolved and oversaturated, it was evaluated the feasibility of using these reduced compounds as electron donors to remove $80 \mathrm{mg} \mathrm{NO}{ }_{x}{ }^{-} \mathrm{N} / \mathrm{L}$ at different hydraulic retention times (HRT) obtaining the optimum at $2 \mathrm{~h}$. In addition, the influence of the $\mathrm{NO}_{2}{ }^{-} / \mathrm{NO}_{3}{ }^{-}$ ratio $(100 \% / 0 \% ; 50 \% / 50 \% ; 25 \% / 75 \%$ and $0 \% / 100 \%$ ) in the feed was studied. Satisfactory results were obtained achieving total nitrogen removal in the denitrifying effluent, being aware of the case with $100 \% \mathrm{NO}_{3}{ }^{-}$in the feed, that was at the limit of the process. Methane was the main electron donor used to remove the nitrites and nitrates, with more than $70 \%$ of participation.
\end{abstract}

Keywords: $\mathrm{COD} \bullet$ Denitrification $\bullet$ Denitritation $\bullet$ methane $\bullet$ sulfide 


\section{INTRODUCTION}

Anaerobic treatment process has been widely applied to various types of wastewater because it has many advantages over the aerobic treatment. Among its advantages it is noteworthy its low energy consumption, reduced production of excess sludge and it transforms the organic matter into valuable biogas. The anaerobic treatments have drawbacks such as process sensitivity, vulnerability, odor problems, long start-up period, and post treatments to achieve discharge standards because components such as nitrogen compounds are not removed efficiently in anaerobic reactors ${ }^{[1-4]}$. Thus, the need to improve the quality of effluents from anaerobic reactors has driven researchers to study alternative post-treatment systems.

Nitrogen compounds discharged into the environment can induce serious problems such as the eutrophication of rivers affecting aquatic life and deterioration of water sources, as well as hazards to human health and the environment. Furthermore, nitrites and nitrates can also form nitrosamines, potentially carcinogenic compounds ${ }^{[5-7]}$. As a result, development of economical and sustainable techniques for reducing the nitrogen content from wastewater has attracted a great deal of attention lately ${ }^{[8]}$. The most widely used method for nitrogen removal in municipal wastewater treatment plants (WWTP) is the combined treatment by aerobic autotrophic nitrification of $\mathrm{NH}_{4}^{+}$to $\mathrm{NO}_{2}{ }^{-}$and $\mathrm{NO}_{3}{ }^{-}$, followed by anoxic heterotrophic denitrification of the oxidized nitrogen species to $N_{2}$ gas. The denitrification potential of wastewater is mainly governed by the available biodegradable organic carbon, commonly expressed as the $\mathrm{C} / \mathrm{N}$ ratio -biodegradable $(\mathrm{COD} / \mathrm{N})$ or biological oxygen demand/nitrogen $(\mathrm{BOD} / \mathrm{N})$ ratio- ${ }^{[9]}$. The conventional heterotrophic denitrification processes are quite effective provided that wastewater contains adequate amount of organic matter. However, when the influent $\mathrm{COD} / \mathrm{NO}_{3}-\mathrm{N}$ ratio is lower than 6 , nitrogen removal is likely to be limited by the lack of available organic carbon source ${ }^{[4,9-11]}$. As anaerobic reactors remove a significant fraction of the organic matter, the available $\mathrm{C} / \mathrm{N}$ ratio in wastewater is low. So, the denitrification step can be achieved by adding an external carbon source, such as ethanol, methanol, or acetic acid. However, the use of external carbon sources increases the operating cost and the sludge production $^{[4,12]}$.

$\mathrm{NO}_{2}{ }^{-}$is an intermediate in both nitrification and denitrification reaction pathways. In the combined conventional nitrification/denitrification process, $\mathrm{NH}_{4}{ }^{+}$is oxidized to $\mathrm{NO}_{2}{ }^{-}$and then to $\mathrm{NO}_{3}{ }^{-}$, which is again converted to $\mathrm{NO}_{2}{ }^{-}$before $\mathrm{N}_{2}$ gas formation. Therefore, the production of $\mathrm{NO}_{3}{ }^{-}$is not required to complete the whole nitrogen removal process. The partial nitrification techniques aim to keep $\mathrm{NO}_{3}{ }^{-}$out of the treatment system and promote the conversion of 
ammonia to nitrite (nitritation) for subsequent direct reduction of nitrite to $\mathrm{N}_{2}$ gas, denitritation. The application of the nitritation/denitritation process instead of complete nitrification/denitrification reduces the treatment costs thanks to $25 \%$ less aeration and $40 \%$ less biodegradable COD consumption. Therefore, the process becomes highly cost effective for the treatment of domestic wastewater with low $\mathrm{C} / \mathrm{N}$ ratio, because the organic carbon source in it is typically limiting. Moreover, it is known that denitrification reaction rates for $\mathrm{NO}_{2}{ }^{-}$are $1.5-2$ times faster than for $\mathrm{NO}_{3}{ }^{-}$allowing higher removal capacities. Furthermore, sludge production is reduced by $40 \%$ in shortcut nitrification/denitrification ${ }^{[9,13]}$.

As well as biogas is produced in anaerobic reactors, the effluent from a low-temperature anaerobic sewage system contains significant amounts of the gaseous products dissolved in the liquid phase. Those gaseous products may be unintentionally emitted into the atmosphere causing a negative process carbon footprint ${ }^{[2,14,15]}$. Methane loss becomes especially important at low operational temperature processes since the solubility of this compound in the liquid phase inversely depends on temperature ${ }^{[16]}$. Methane is a greenhouse gas that has an effect on global warming 25 times stronger than that of carbon dioxide. Therefore, the management of dissolved methane is necessary to limit greenhouse gas emissions ${ }^{[2-4,14,15,17,18]}$. On the other hand, sulfide, which is also produced in anaerobic treatment, represents an environmental problem, because of its corrosive properties, odor, toxicity and $\operatorname{COD}^{[4,12,19]}$.

Frequently, methane and sulfide oversaturation occurs. If the effluent containing those compounds is discharged, methane and sulfide would be released to the atmosphere. Several authors have reported on anaerobic effluents that are oversaturated with dissolved methane, which demonstrates that dissolved methane and sulfide concentrations can be higher than those predicted based on Henry's law, ostensibly due to the formation of microbubbles ${ }^{[15,20]}$.

Considering the undesirable impacts of sulfide and dissolved methane in anaerobic effluents, it makes sense to evaluate the efficacy of using either or both as electron donors for nitrogen removal when stringent nitrogen discharge limits apply. The electron donors typically present in anaerobic effluents are preserved in solution as organic COD not removed during anaerobic treatment, dissolved methane and sulfide. These compounds may be used by denitrifying bacteria to achieve nitrogen removal via nitrite or nitrate ${ }^{[19]}$.

The objective of this work was to evaluate the viability of the partial and total denitrification of the effluent of an anaerobic membrane bioreactor (AnMBR) that treated domestic wastewater under psychrophilic conditions, using organic matter, methane and sulfide as 
electron donors. Nitrite and/or nitrate were the electron acceptors of the wastewater with a low $\mathrm{C} / \mathrm{N}$ ratio. The remained organic carbon compounds were removed by the heterotrophic denitrification process. Methane was oxidized to carbon dioxide, while sulfide to sulfate and insoluble element sulfur. Nitrate and nitrite were converted to nitrogen gas that would not cause secondary pollution. ${ }^{[21]}$

\section{MATERIALS AND METHODS}

\subsection{Experimental Setup}

A schematic diagram of the denitrification plant is given in Figure 1. For the fixed film bioreactor studies, an anoxic continuous up-flow reactor with a working volume of $21 \mathrm{~L}$ and a total volume of $26 \mathrm{~L}$ was used. The filter made of PVC glass consisted of a cylindrical column with a height of $1.5 \mathrm{~m}$ and diameter of $0.15 \mathrm{~m}$. The reactor was filled with corrugated PVC rings (with an inner diameter of $12 \mathrm{~mm}$ and $17 \mathrm{~mm}$ of length), which served as support where the biomass was attached. The temperature of operation was between $18^{\circ} \mathrm{C}$ and $20^{\circ} \mathrm{C}$. The plant was operated under continuous flow. The inoculum was formed by $10 \mathrm{~L}$ of not thickened secondary sludge taken from the WWTP of Valladolid (Spain) and $2 \mathrm{~L}$ of thermophilic anaerobic sludge, coexisting nitrate/nitrite reducers and methanogenic cultures in the system.

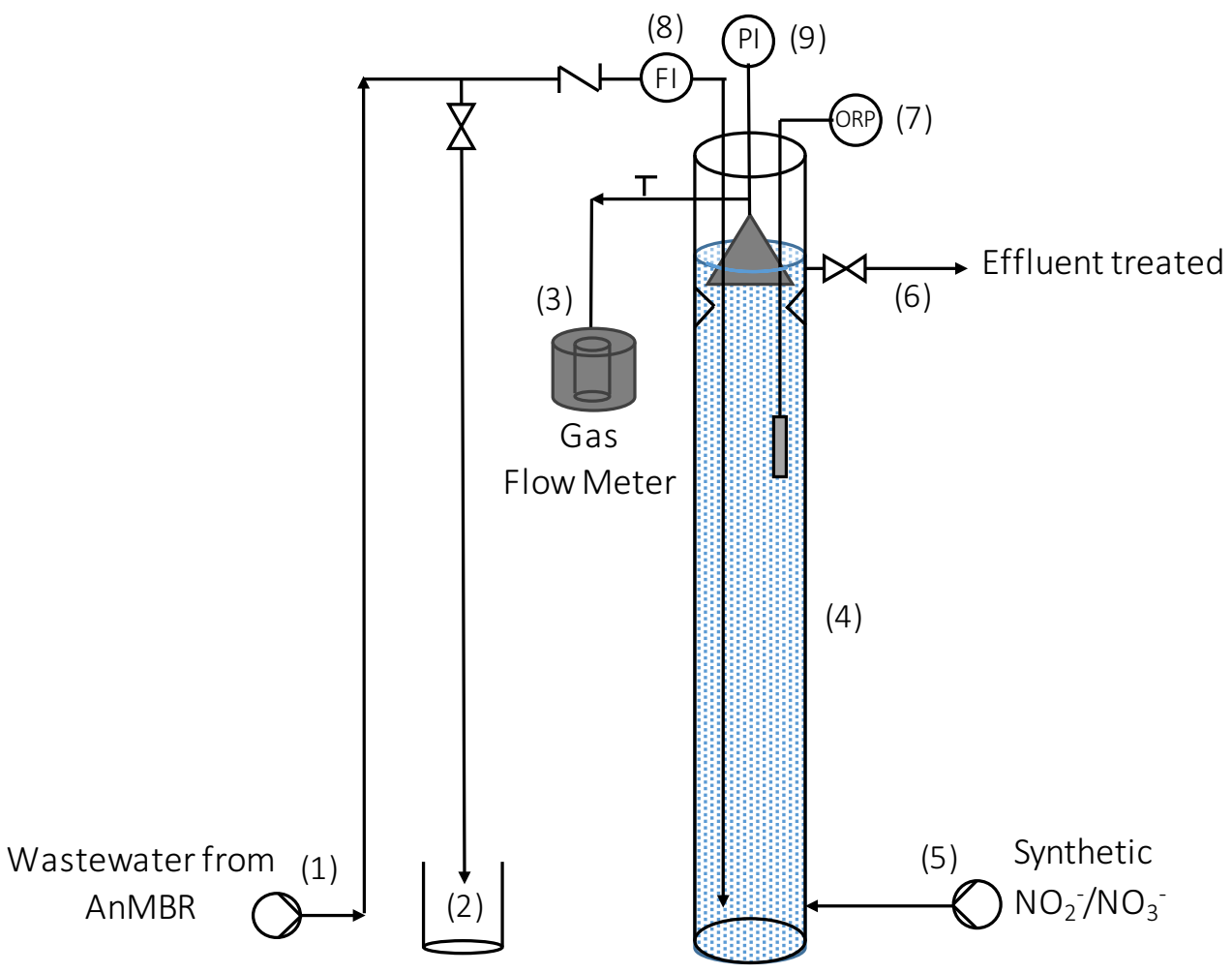

Figure 1: Scheme of the denitrification/denitritation plant. (1) Filling pump, supplies the wastewater to be treated, (2) Tank with the water that does not enter in process. (3) Gas collection chamber, (4) 
Bioreactor, (5) Pump that supply the synthetic $\mathrm{NO}_{2}{ }^{-} / \mathrm{NO}_{3}{ }^{-}$solution, (6) Current of the effluent treated, (7) Oxidation/reduction potential meter, (8) Flow indicator, (9) Pressure gauge.

\subsection{Feeding Characteristics}

The studied reactor was fed continuously with the effluent from an AnMBR treating domestic wastewater under psychrophilic conditions, and a medium of sodium nitrite and sodium nitrate, to simulate the effluent from a previous nitrification process. The AnMBR pilot plant is explained in detail in a previous work ${ }^{[2]}$. This feeding strategy tries to simulate the operation of a real wastewater treatment plant using an anaerobic reactor as the first treatment unit. The characteristics of the water after anaerobic treatment are shown in Table 1.

Table 4: Average values of the influent during all the work (on the left in the table). Nitrites and nitrates concentration in every stage (on the right in the table).

\begin{tabular}{|c|c|c|c|c|c|}
\hline Parameter & Inlet concentration & & & & \\
\hline $\mathrm{sCOD}\left(\mathrm{mg} \mathrm{O}_{2} / \mathrm{L}\right)$ & 116.9 & & & & \\
\hline TKN (mg N/L) & 98.3 & & & & \\
\hline $\mathrm{NH}_{4}^{+}(\mathrm{mg} \mathrm{N} / \mathrm{L})$ & 88.0 & Stage 1 & Stage 2 & Stage 3 & Stage 4 \\
\hline $\mathrm{NO}_{2}^{-} \quad(\mathrm{mg} \mathrm{N} / \mathrm{L})$ & 80.0 & 80 & 40 & 20 & 0 \\
\hline $\mathrm{NO}_{3}^{-}(\mathrm{mg} \mathrm{N} / \mathrm{L})$ & & 0 & 40 & 60 & 80 \\
\hline $\mathrm{SO}_{4}{ }^{2-}(\mathrm{mg} \mathrm{S} / \mathrm{L})$ & 10.8 & & & & \\
\hline sol $P \quad(m g P / L)$ & 13.8 & & & & \\
\hline
\end{tabular}

$\mathrm{NO}_{x}{ }^{-} \mathrm{N}$ in the feeding was kept around $80 \mathrm{mg} / \mathrm{L}$. That value was assumed because as it can be seen in Table 1, the concentration of nitrogen in the ammonium form is about $88 \mathrm{mg} \mathrm{N} / \mathrm{L}$. This amount is oxidized in the nitrification step producing that concentration of nitrogen, in the form of nitrite and/or nitrate. Assuming a nitrification yield of $90 \%$, it was gotten the value of 80 mg $\mathrm{NO}_{x}{ }^{-} \mathrm{N} / \mathrm{L}$ as feeding concentration. Throughout the investigation $\mathrm{NO}_{2}{ }^{-} / \mathrm{NO}_{3}{ }^{-}$ratios were

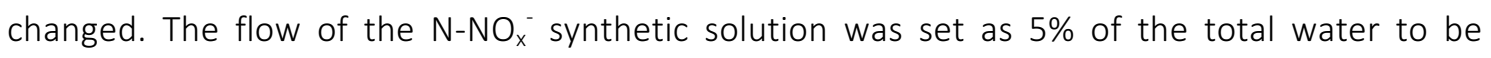
treated to avoid excessive dilution. The wastewater to be treated in the proposed denitrification process, contain a very low $\mathrm{C} / \mathrm{N}$ ratio, around 1.3 .

The effluent from a low-temperature anaerobic treatment contains a considerable amount of dissolved methane and sulfide, which can be used as electron donors by the denitrifying bacteria. Assuming atmospheric pressure, 15으 $\mathrm{C}$ and knowing the percentage of methane and sulfide in the anaerobic reactor biogas, $84 \%$ and $0.2 \%$ respectively, the concentration of dissolved methane and sulfide can be calculated according to Henry's law, resulting in $22 \mathrm{mg}$ 
$\mathrm{CH}_{4} / \mathrm{L}$ and $9 \mathrm{mg} \mathrm{H} \mathrm{H}_{2} \mathrm{~S} / \mathrm{L}$ respectively. Some experimental tests were performed to calculate the oversaturation of methane (in liquid phase) in the water to be treated (from AnMBR) resulting in 20-40 mg CH $4 / \mathrm{L}$. Therefore, the amount of methane and sulfide dissolved and oversaturated, is the available quantity of these compounds in the reactor to perform the denitrification process.

\subsection{Analytical Methods}

Samples of wastewater were taken before and after finishing the denitrification or denitritation process. The concentration of nitrite, nitrate and soluble phosphorus were measured by High Performance Liquid Chromatography (HPLC). Ammonium concentration was determined using an ammonia-selective electrode: Orion, model 9512HPBNWP. The analyses of Chemical Oxygen Demand (COD), Total Kjeldahl Nitrogen (TKN) as well as total and volatile suspended solids (TSS, VSS) were determined according to standard methods suggested by the Standard methods manual ${ }^{[22]}$. The measurement of dissolved oxygen concentration was determined with an oximeter WTW, model oxi 330/SET and a dissolved oxygen probe CeliOx 325. Gas production was measured volumetrically by water displacement, and its composition in terms of methane, carbon dioxide, nitrogen, oxygen, hydrogen sulfide and hydrogen was determined by gas chromatography (GC) (Varian CP-3800). Pressure, temperature and oxidation-reduction potential (ORP) were measured by using sensors and probes.

\subsection{Operation Strategy}

In the first part of the work, denitrification efficiency was studied at different hydraulic retention times (HRT) in order to investigate the optimum treatment time conditions for nitrite and nitrate removal. During this study the concentration of $\mathrm{NO}_{x}-\mathrm{N}$ in the feeding was around 80 $\mathrm{mg} / \mathrm{L}$ and the ratio of $\mathrm{NO}_{2}{ }^{-} / \mathrm{NO}_{3}{ }^{-}$was set at $50 \% / 50 \%$, corresponding to the stage 2 , as described in Table 2. The reactor removal efficiency was evaluated at the different following HRT: 8h, 6h, $4 \mathrm{~h}, 2 \mathrm{~h}$ and $1.5 \mathrm{~h}$, by changing the reactor feeding flow from $2.6 \mathrm{~L} / \mathrm{h}$ to $14 \mathrm{~L} / \mathrm{h}$.

Table 5: Average concentrations of $\mathrm{NO}_{2}{ }^{-} \mathrm{N}$ and $\mathrm{NO}_{3}{ }^{-} \mathrm{N}$ at different HRT.

\begin{tabular}{llcccccc}
\multicolumn{1}{c}{ Stage 2 } & & $8 \mathrm{~h}$ & $6 \mathrm{~h}$ & $4 \mathrm{~h}$ & $2 \mathrm{~h} 30$ & $2 \mathrm{~h}$ & $1 \mathrm{~h} 30$ \\
\hline $\mathrm{NO}_{2}^{-}$ & Inlet & 43.8 & 49.5 & 43.9 & 46.6 & 41.7 & 47.9 \\
$(\mathrm{mg} \mathrm{N} / \mathrm{L})$ & Outlet & 0.0 & 0.0 & 0.0 & 0.0 & 0.0 & 2.0 \\
$\mathrm{NO}_{3}^{-}$ & Inlet & 35.8 & 44.3 & 38.5 & 34.9 & 35.7 & 32.1 \\
$(\mathrm{mg} \mathrm{N} / \mathrm{L})$ & Outlet & 0.0 & 0.0 & 0.0 & 0.0 & 0.0 & 2.9
\end{tabular}


Once it was found the optimum HRT for the process, the second part of the work was focused on the study of the reactor behavior when $\mathrm{NO}_{2}{ }^{-} / \mathrm{NO}_{3}{ }^{-}$ratios were changed. Stage 1 corresponds to denitritation with a feeding of about $80 \mathrm{mg} \mathrm{NO}{ }^{-} \mathrm{N} / \mathrm{L}$ (ratio $\mathrm{NO}_{2}{ }^{-} / \mathrm{NO}_{3}{ }^{-}$: 100\%/0\%). Stage 2 when the feeding was $40 \mathrm{mg} \mathrm{NO}{ }^{-}-\mathrm{N} / \mathrm{L}$ and $40 \mathrm{NO}_{3}{ }^{-} \mathrm{N} / \mathrm{L}(50 \% / 50 \%)$. Stage 3 when the feed concentration was $20 \mathrm{NO}_{2}{ }^{-} \mathrm{N} / \mathrm{L}$ and $60 \mathrm{NO}_{3}{ }^{-} \mathrm{N} / \mathrm{L}(25 \% / 75 \%)$. And in the stage 4 is represented the denitrification with a feed of around $80 \mathrm{mg} \mathrm{NO}{ }_{3}{ }^{-} \mathrm{N} / \mathrm{L}(0 \% / 100 \%)$. The procedure carried out in the stages is shown in the right part of the Table 1.

\section{RESULTS AND DISCUSSION}

In this study, using an anoxic fixed film reactor, it was performed the nitrogen removal from real wastewater with the organic matter not removed in the preceding anaerobic process, and the dissolved and oversaturated biogas (methane and sulfide) available in the water.

\subsection{Optimization of the residence time.}

The first part of the work had a duration of 130 days. Denitrification efficiency was studied at different HRT by changing the feeding flow.

As shown in the Table 2, in this study the concentration of the $\mathrm{NO}_{x}{ }^{-} \mathrm{N}$ in the feeding was around $80 \mathrm{mg} / \mathrm{L}$ and the ratio of $\mathrm{NO}_{2}{ }^{-} / \mathrm{NO}_{3}{ }^{-}$was set at $50 \% / 50 \%$. The effluent was studied decreasing the HRT from 8 to 1.5 hours (Table 2) with the aim of determining the optimum treatment time conditions for the nitrate and nitrite removal.

During this study at fixed influent rate of nitrite and nitrate (50\%/50\%), with HRT decreasing from 8 to 2 hours, the removal efficiency was 100\% with an effluent free of oxidized nitrogen compounds. Total elimination of $\mathrm{NO}_{2}{ }^{-}$and $\mathrm{NO}_{3}{ }^{-}$was not detected when working with HRT less than 2 hours. At 1.5 hours of HRT, the removal efficiency of nitrite and nitrate was about 96\% and $90 \%$ respectively, obtaining $5 \mathrm{mg} \mathrm{NO}{ }^{-}-\mathrm{N} / \mathrm{L}$ of concentration average in the outlet.

Judging by these results, denitrification of a domestic wastewater from a AnMBR was feasible and its optimum HRT for nitrate and nitrite removal was 2 hours.

Looking at the literature, on the one hand, Zhou $W$ et al. by using an upflow biofilter for denitrification achieved a high yield of nitrate removal at $8 \mathrm{~h}$ of HRT ${ }^{[23]}$. On the other hand, in the $\mathrm{A} 2 \mathrm{O}$ process proposed by Zheng $\mathrm{W}$ et al., a $50 \%$ of nitrate removal was reached when HRT was $3 \mathrm{~h}^{[24]}$ and a $85 \%$ at $4.35 \mathrm{~h}^{[13]}$ when treating an effluent with a low $\mathrm{C} / \mathrm{N}$ ratio (about 2.5). However, the resulting HRT obtained in the current work is much lower than previously reported in literature. This represent an advantage when thinking in scaling-up the process. 


\subsection{Nitrite and nitrate removal at different feeds.}

With the objective of study the viability of the process for partial and total denitrification, the HRT was kept at $2 \mathrm{~h}$, as optimized in the previous section. The feed flow was fixed at 10.5 $\mathrm{L} / \mathrm{h}$ while the ratio of the nitrite and nitrate concentration was changed (right part of Table 2).

The average concentrations of the main parameters in the inlet and outlet of the denitrification process can be seen in the Table 3.

TKN is a measure of both total organic nitrogen and ammoniacal nitrogen in wastewater. As expected, the TKN, whose $\mathrm{NH}_{4}{ }^{+}$composition exceeded $90 \%$, did not vary during the treatment, because nitrification is unlikely to have occurred due to the low DO levels in the reactor. No modification of soluble phosphorus was observed during the process.

In all the cases, the bioreactor was able to remove all the $\mathrm{NO}_{2}^{-}-\mathrm{N}$, attaining efficiency about $100 \%$. The progress of nitrite and nitrate in the reactor during the denitrification process for different ratios is depicted in Figure 2. This figure comprises four graphs, each representing a feed. In all the feeds can be seen the reactor behavior for the inlet of $80 \mathrm{mg} \mathrm{NO}{ }_{x}-\mathrm{N} / \mathrm{L}$ with the corresponding ratios. In all the cases, nitrite and/or nitrite reduction started without any delay and resulted in the formation of $\mathrm{N}_{2}$. The stage 4 was the most unfavorable case of denitrification with a $100 \%$ of nitrate as feeding. In fact, nitrates were found in the effluent. Although in this stage the mean concentration of nitrate in the effluent was $4.9 \mathrm{mg} \mathrm{NO}{ }_{3}^{-} \mathrm{N} / \mathrm{L}$, it can be noticed that punctually reached $19 \mathrm{mg} \mathrm{NO}_{3}{ }^{-} \mathrm{N} / \mathrm{L}$, higher value than the allowable limit. This indicate a not good yield of the process, being in the limit removal of reactor. 
Table 6: Average parameters for different $\mathrm{NO}_{2}{ }^{-} / \mathrm{NO}_{3}{ }^{-}$ratios on denitrification.

\begin{tabular}{|c|c|c|c|c|c|c|c|c|}
\hline \multirow[b]{2}{*}{ Parameter } & \multicolumn{2}{|c|}{ Stage 1} & \multicolumn{2}{|c|}{ Stage 2} & \multicolumn{2}{|c|}{ Stage 3} & \multicolumn{2}{|c|}{ Stage 4} \\
\hline & Inlet & Outlet & Inlet & Outlet & Inlet & Outlet & Inlet & Outlet \\
\hline $\begin{array}{l}\mathrm{sCOD} \\
\left(\mathrm{mg} \mathrm{O}_{2} / \mathrm{L}\right)\end{array}$ & $107.7 \pm 10.9$ & $73.7 \pm 7.4$ & $100.1 \pm 5.7$ & $66.7 \pm 5.7$ & $102.9 \pm 3.3$ & $68.1 \pm 2.3$ & $106.7 \pm 17.2$ & $58.6 \pm 10.3$ \\
\hline $\begin{array}{l}\text { TKN } \\
(\mathrm{mg} \mathrm{N} / \mathrm{L})\end{array}$ & $82.2 \pm 3.1$ & $82.0 \pm 4.6$ & $107.2 \pm 3.6$ & $110.8 \pm 4.9$ & $121.7 \pm 5.0$ & $118.8 \pm 3.9$ & $97.8 \pm 7.3$ & $97.4 \pm 9.8$ \\
\hline $\begin{array}{l}\mathrm{NH}_{4}{ }^{+} \\
(\mathrm{mg} \mathrm{N} / \mathrm{L})\end{array}$ & $76.4 \pm 1.2$ & $77.7 \pm 2.4$ & $93.5 \pm 3.8$ & $92.9 \pm 4.1$ & $120.4 \pm 4.9$ & $116.0 \pm 4.2$ & $90.6 \pm 10.6$ & $85.8 \pm 6.6$ \\
\hline $\begin{array}{l}\mathrm{NO}_{2}^{-} \\
(\mathrm{mg} \mathrm{N} / \mathrm{L})\end{array}$ & $79.1 \pm 3.0$ & $1.3 \pm 4.0$ & $41.7 \pm 2.0$ & $0.2 \pm 0.9$ & $25.9 \pm 0.7$ & $0.3 \pm 2.1$ & $0.0 \pm 0.0$ & $0.2 \pm 1.5$ \\
\hline $\begin{array}{l}\mathrm{NO}_{3}{ }^{-} \\
(\mathrm{mg} \mathrm{N} / \mathrm{L})\end{array}$ & $0.0 \pm 0.0$ & $0.3 \pm 0.6$ & $35.7 \pm 1.7$ & $0.2 \pm 0.6$ & $46.1 \pm 0.9$ & $1.0 \pm 3.8$ & $78.4 \pm 1.6$ & $4.6 \pm 5.4$ \\
\hline $\begin{array}{l}\mathrm{SO}_{4}{ }^{2-} \\
(\mathrm{mg} \mathrm{S} / \mathrm{L})\end{array}$ & $10.7 \pm 9.5$ & $20.4 \pm 7.5$ & $8.7 \pm 5.0$ & $21.4 \pm 6.0$ & $8.8 \pm 10.4$ & $41.1 \pm 10.9$ & $9.9 \pm 6.3$ & $48.3 \pm 10.2$ \\
\hline $\begin{array}{l}\text { soluble } P \\
(\mathrm{mg} P / L)\end{array}$ & $10.3 \pm 1.0$ & $10.8 \pm 1.3$ & $13.9 \pm 0.8$ & $14.5 \pm 1.4$ & $14.6 \pm 3.6$ & $13.0 \pm 1.4$ & $9,8 \pm 0.8$ & $10.1 \pm 2.0$ \\
\hline
\end{tabular}



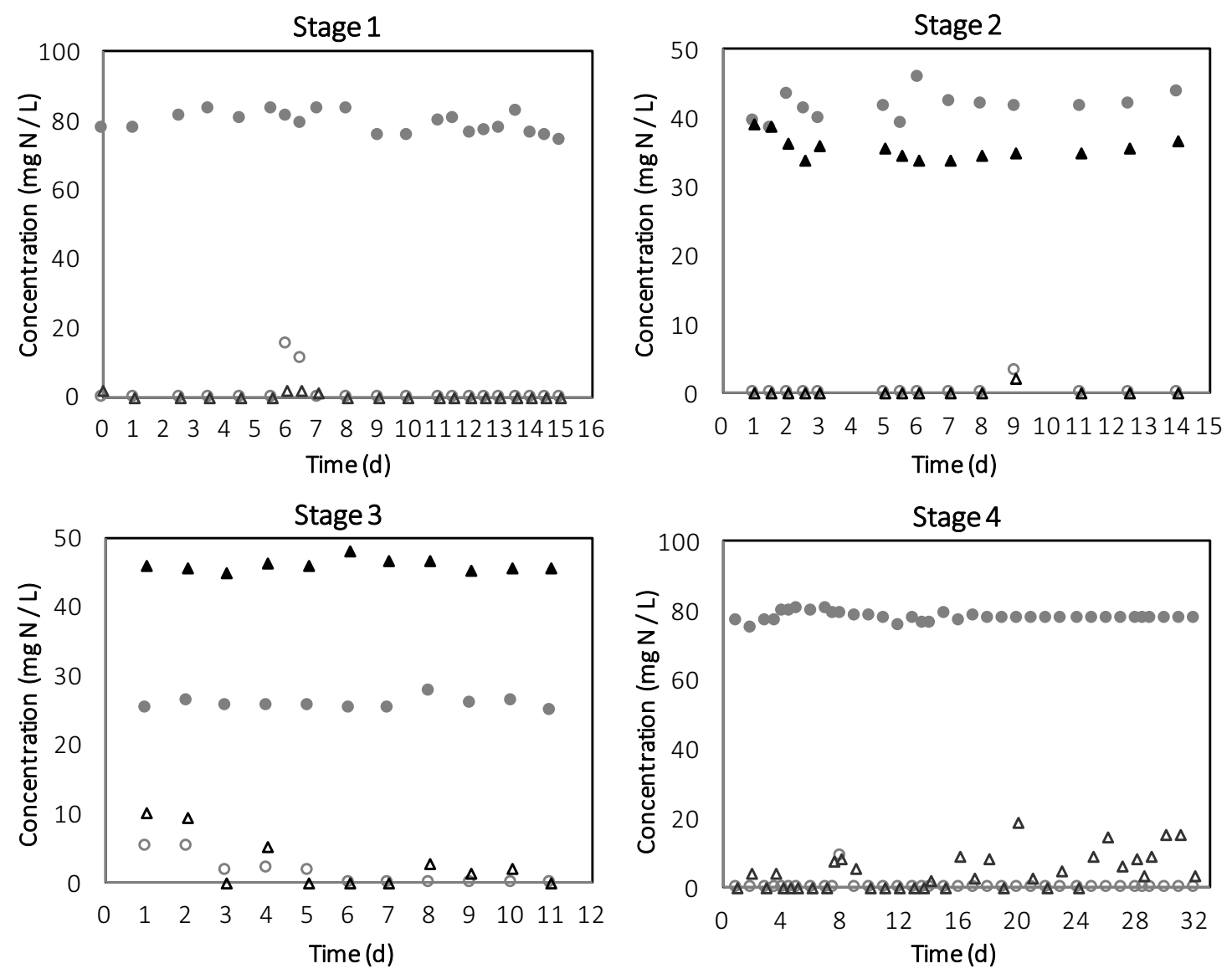

- In $\mathrm{NO}_{2}{ }^{-} \mathrm{N} \quad \boldsymbol{\Delta}$ In $\mathrm{NO}_{3}{ }^{-}-\mathrm{N} \quad$ O Out $\mathrm{NO}_{2}{ }^{-}-\mathrm{N} \quad \triangle$ In $\mathrm{NO}_{3}{ }^{-}-\mathrm{N}$

Figure 2: Influent and effluent of $\mathrm{NO}_{2}{ }^{-}$and $\mathrm{NO}_{3}{ }^{-}$. (Stage 1) $100 \% \mathrm{NO}_{2}{ }^{-}$; (Stage 2) $50 \% \mathrm{NO}_{2}{ }^{-} / 50 \% \mathrm{NO}_{3}{ }^{-}$; (Stage 3) $25 \%$ $\mathrm{NO}_{2}{ }^{-} / 75 \% \mathrm{NO}_{3}{ }^{-}$and (Stage 4) $100 \% \mathrm{NO}_{3}{ }^{-}$.

The experimental percentages of organic matter removal are between $35 \%-40 \%$, and the values of COD removal correspond to the biological oxygen demand (BOD) available in the feeding wastewater. The COD removed is consumed by the bacteria in the denitrification process.

As Table 3 shows, simultaneously to the denitrification occurrence, an increase of sulfate concentration was observed from stage 1 to 4 . This can be explained because the denitrifying bacteria need more sulfide to remove nitrate than nitrite. As consequence, more sulfate is formed. Stoichiometrically, sulfate concentration in the effluent should be between $50 \%$ and $65 \%$ higher than experimental data. In all stages of operation, the anoxic sulfide oxidation took place via partial and total oxidation producing elemental sulfur and sulfate. The milky appearance inside the reactor suggested the elemental sulfur production, as an intermediate product, probably higher then expected. The insoluble elemental sulfur was accumulated inside the reactor in the lower section because of its precipitation. Due to the difficulty of separating solid sulfur from biomass elemental sulfur could not be analyzed. Therefore, sulfate 
concentration was lower than expected stoichiometrically, due to the higher formation of elemental sulfur. It was assumed that all sulfide removed, but not recovered as sulfate, was converted to elemental sulfur. Throughout the study, the gas phase from the top of the reactor was analyzed by gas chromatography, resulting in about $0 \%$ of $\mathrm{H}_{2} \mathrm{~S}$.

As reported in the literature ${ }^{[4,25]}$, there are indications that denitrification occurs more easily by using sulfur compounds than methane. The activity of methanotrophic microorganisms is much lower than that of autotrophic sulfide denitrifiers. Therefore, it is suggested that the first electron donor used for denitrification after the organic matter was not methane, but the hydrogen sulfide present in the water after anaerobic treatment. After all electrons from sulfide were consumed, denitrification/denitritation with methane started.

\subsection{Balances of the denitrification with organic matter, sulfide and methane.}

The mass balance of different species over the reactor gives an indication about the functioning of the system. To get further evidence about the nature of the process, a stoichiometric analysis of the consumption of $\mathrm{OM}, \mathrm{H}_{2} \mathrm{~S}$ and $\mathrm{CH}_{4}$ was carried out.

From the reactions that take place in the process of denitrification with the three different electron donors available in the wastewater, it can be calculated the stoichiometric needs of each one to reduce nitrite and nitrate (Table 4).

Table 7: Average parameters for different $\mathrm{NO}_{2}{ }^{-} / \mathrm{NO}_{3}{ }^{-}$ratios on denitrification.

\begin{tabular}{ccc} 
Ratios & $\mathrm{NO}_{2}^{-}$ & $\mathrm{NO}_{3}^{-}$ \\
\hline $\mathrm{OM}(\mathrm{mg} \mathrm{COD} / \mathrm{mg} \mathrm{N})$ & 2.4 & 4.0 \\
$\mathrm{~S}^{2-}(\mathrm{mg} \mathrm{S} / \mathrm{mg} \mathrm{N})$ & 1.4 & 2.3 \\
$\mathrm{CH}_{4}(\mathrm{mg} \mathrm{CH} / \mathrm{mg} \mathrm{N})$ & 0.4 & 0.7
\end{tabular}

The concentrations of organic matter, sulfide, nitrite and nitrate in water can be measured empirically as explained previously in the analytical methods section, and are shown in Table 3. Dividing this value by the corresponding number in Table 4, it is obtained the amount of nitrites and/or nitrates removed with organic matter and sulfide for each study phase. For example, in the stage 1: From Table 3, $(107.7-73.7)=34 \mathrm{mg}$ COD/L removed; $34(\mathrm{mg}$ COD/L) / $2.4(\mathrm{mg}$ $\left.\mathrm{COD} / \mathrm{mg} \mathrm{NO}_{2}{ }^{-} \mathrm{N}\right)=14.2 \mathrm{mg} \mathrm{NO}_{2}{ }^{-} \mathrm{N} / \mathrm{L}$ are removed with the organic matter as electron donor. These results are presented in Table 5. 
Table 8: Concentration and percentage contribution of different donors in the elimination.

\begin{tabular}{|c|c|c|c|c|c|c|c|c|}
\hline \multirow[b]{2}{*}{$\mathrm{NO}_{2}^{-} / \mathrm{NO}_{3}^{-}$} & \multicolumn{2}{|c|}{ Stage 1} & \multicolumn{2}{|c|}{ Stage 2} & \multicolumn{2}{|c|}{ Stage 3} & \multicolumn{2}{|c|}{ Stage 4} \\
\hline & $\mathrm{NO}_{2}^{-}$ & $\mathrm{NO}_{3}^{-}$ & $\mathrm{NO}_{2}^{-}$ & $\mathrm{NO}_{3}^{-}$ & $\mathrm{NO}_{2}^{-}$ & $\mathrm{NO}_{3}^{-}$ & $\mathrm{NO}_{2}^{-}$ & $\mathrm{NO}_{3}^{-}$ \\
\hline Initial (mg N/L) & 80 & 0 & 40 & 40 & 20 & 60 & 0 & 80 \\
\hline $\begin{array}{c}\text { OM } \\
\text { (mg Nelim/L) }\end{array}$ & $\begin{array}{c}14.2 \\
(17.7 \%)\end{array}$ & - & $\begin{array}{c}13.9 \\
(34.8 \%)\end{array}$ & - & $\begin{array}{c}14.5 \\
(72.5 \%)\end{array}$ & 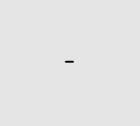 & - & $\begin{array}{c}11.2 \\
(14.0 \%)\end{array}$ \\
\hline $\begin{array}{c}\mathrm{S}^{2-} \\
\text { (mg Nelim/L) }\end{array}$ & $\begin{array}{c}7.8 \\
(9.8 \%)\end{array}$ & - & $\begin{array}{c}6.4 \\
(16.0 \%)\end{array}$ & - & $\begin{array}{c}5.5 \\
(27.5 \%)\end{array}$ & $\begin{array}{c}0.6 \\
(1.0 \%)\end{array}$ & - & $\begin{array}{c}4.3 \\
(5.4 \%)\end{array}$ \\
\hline $\begin{array}{c}\mathrm{CH}_{4} \\
(\mathrm{mg} \mathrm{Nelim} / \mathrm{L})\end{array}$ & $\begin{array}{c}58.0 \\
(72.5 \%)\end{array}$ & - & $\begin{array}{c}19.7 \\
(49.2 \%)\end{array}$ & $\begin{array}{c}40 \\
(100.0 \%)\end{array}$ & & $\begin{array}{c}59.4 \\
(99.0 \%)\end{array}$ & - & $\begin{array}{c}64.5 \\
(80.6 \%)\end{array}$ \\
\hline
\end{tabular}

Nitrates and nitrites are removed firstly using the organic matter and sulfides. Once consumed all the organic matter easily biodegradable and sulfides, nitrates and nitrites are eliminated by methane consumption. Numbers in brackets indicate the percentage of nitrites and nitrates removed with each electron donor.

The amount of methane required for the process is obtained by multiplying the amount of nitrites and/or nitrates removed with this electron donor, and the stoichiometric ratio of Table 4. These concentrations were $24.9 \mathrm{mg} \mathrm{CH}_{4} / \mathrm{L}, 36.9 \mathrm{mg} \mathrm{CH}_{4} / \mathrm{L}, 42.2 \mathrm{mg} \mathrm{CH} / / \mathrm{L}$ and $45.8 \mathrm{mg} \mathrm{CH}_{4} / \mathrm{L}$ respectively. So, in the stage 4 , which represents the least favorable denitrification (total denitrification), to achieve complete removal of nitrates, the amount of methane needed as electron donor was $45.8 \mathrm{mg} \mathrm{CH}_{4} / \mathrm{L}$.

This methane available for the system was, on the one side dissolved in the wastewater, and in the other side, desorbed when entering into the reactor because its oversaturated state. As indicated in the feeding characteristics, about $22 \mathrm{mg} \mathrm{CH} / \mathrm{L}$ was the dissolved methane, and between 20-40 mg CH $\mathrm{CH}_{4} / \mathrm{L}$ was the oversaturated one. Therefore, there was enough amount of methane and balances are justified. It should be noted from the stage 4, that methane may not be enough to carry out the complete denitrification if it is available only at the minimum value of oversaturation.

Based on the results of the balances, methane was by far the most used electron by bacteria. This can be explained because of the higher amount of methane available in water, but in fact, the organic matter and sulfide were the first compounds to be consumed. In the balances, it was not taken into account the nitrogen consumed for cell synthesis. 


\section{CONCLUSIONS}

The denitrification of domestic wastewater with a low concentration of COD could be possible, by using the methane and sulfide that contains the water after the anaerobic treatment. $\mathrm{NO}_{2}{ }^{-}$and $\mathrm{NO}_{3}{ }^{-}$were the electron acceptors, while the $\mathrm{OM}, \mathrm{CH}_{4}$ and $\mathrm{H}_{2} \mathrm{~S}$ were the electron donors. The results of the work demonstrated that denitritation and denitrification is a feasible process for the simultaneous removal of $\mathrm{NO}_{2}{ }^{-}, \mathrm{NO}_{3}{ }^{-}, \mathrm{OM}, \mathrm{CH}_{4}$ and $\mathrm{H}_{2} \mathrm{~S}$ for real wastewater. Nitrogen removal was demonstrated obtaining a successful $\mathrm{NO}_{2}{ }^{-}$and $\mathrm{NO}_{3}{ }^{-}$ elimination when the feed was $80 \mathrm{mg} \mathrm{N}-\mathrm{NO}_{\mathrm{x}}{ }^{-} / \mathrm{L}$, except when the feeding was formed only by nitrate. In this case, the process was at the limit of the denitrification process, obtaining an effluent at some points up to $19 \mathrm{mg} \mathrm{N}-\mathrm{NO}_{3}{ }^{-} / \mathrm{L}$. The optimal HRT to obtain both, denitritation and denitrification was 2 hours using an anoxic reactor. The amount of methane available in the water was enough to achieve the goal being the main electron donor used with more than $70 \%$ or participation.

\section{ACKNOWLEDGEMENTS}

The authors thank the company Cadagua S.A., the European Regional Development Fund, and the project IPT-2011-1078-310000, and the INNPACTO 2011 program of the Ministry of Economy and Competitiveness for the technical and financial support. 


\section{References}

1. M. Hatamoto, H. Yamamoto, T. Kindaichi, N. Ozaki and A. Ohashi, Biological oxidation of dissolved methane in effluents from anaerobic reactors using a down-flow hanging sponge reactor, Water Research, 2010, 44(5), p.1409-1418.

2. J. Gouveia, F. Plaza, G. Garralon, F. Fdz-Polanco and M. Peña, A novel configuration for an anaerobic submerged membrane bioreactor (AnSMBR). Long-term treatment of municipal wastewater under psychrophilic conditions, Bioresource Technology, 2015, 198510-519.

3. N. Matsuura, M. Hatamoto, H. Sumino, K. Syutsubo, T. Yamaguchi and A. Ohashi, Recovery and biological oxidation of dissolved methane in effluent from UASB treatment of municipal sewage using a two-stage closed downflow hanging sponge system, Journal of Environmental Management, 2015, 151200-209.

4. J. L. R. Pantoja Filho, M. H. R. Z. Damianovic, D. F. Fonseca and E. Foresti, Nitrogen and residual organic matter removal from anaerobic reactor effluent in a fixed-bed reactor with biogas for denitrification, Journal of Chemical Technology \& Biotechnology, 2015, 90(12), p.2227-2233.

5. J. A. Camargo and Á. Alonso, Ecological and toxicological effects of inorganic nitrogen pollution in aquatic ecosystems: A global assessment, Environment International, 2006, 32(6), p.831 - 849 .

6. Y. Fernández-Nava, E. Marañón, J. Soons and L. Castrillón, Denitrification of high nitrate concentration wastewater using alternative carbon sources, Journal of Hazardous Materials, 2010, 173(1-3), p.682 - 688.

7. L. Peng, Y. Liu, S.-H. Gao, X. Chen and B.-J. Ni, Evaluating simultaneous chromate and nitrate reduction during microbial denitrification processes, Water Research, 2016, 891 8.

8. A. Ahmad and A. O-Aljasser, Anaerobic nitrogen, sulfide, and carbon removal in anaerobic granular bed reactor, Environmental Progress \& Sustainable Energy, 2014, 33(4), p.1096-1104.

9. M. Ruscalleda Beylier, M. D. Balaguer, J. Colprim, C. Pellicer-Nàcher, B. J. Ni, B. F. Smets, S. P. Sun and R. C. Wang, in Comprehensive Biotechnology (Second Edition), ed. M. MooYoung, Academic Press, Burlington, 2011, pp. 329-340.

10. E. Sahinkaya, A. Kilic and B. Duygulu, Pilot and full scale applications of sulfur-based autotrophic denitrification process for nitrate removal from activated sludge process effluent, Water Research, 2014, 60210 - 217. 
11. S. J. Jafari, G. Moussavi and K. Yaghmaeian, High-rate biological denitrification in the cyclic rotating-bed biological reactor: Effect of, nitrate concentration and salinity and the phylogenetic analysis of denitrifiers, Bioresource Technology, 2015, 197482 - 488.

12. I. Manconi, A. Carucci and P. Lens, Combined removal of sulfur compounds and nitrate by autotrophic denitrification in bioaugmented activated sludge system, Biotechnology and Bioengineering, 2007, 98(3), p.551-560.

13. W. Zeng, L. Li, Y. Yang, S. Wang and Y. Peng, Nitritation and denitritation of domestic wastewater using a continuous anaerobic-anoxic-aerobic (A2O) process at ambient temperatures, Bioresource Technology, 2010, 101(21), p.8074 - 8082.

14. C. Kampman, T. L. G. Hendrickx, F. A. Luesken, T. A. van Alen, H. J. M. Op den Camp, M. S. M. Jetten, G. Zeeman, C. J. N. Buisman and H. Temmink, Enrichment of denitrifying methanotrophic bacteria for application after direct low-temperature anaerobic sewage treatment, Journal of Hazardous Materials, 2012, 227-228164-171.

15. A. L. Smith, S. J. Skerlos and L. Raskin, Psychrophilic anaerobic membrane bioreactor treatment of domestic wastewater, Water Research, 2013, 47(4), p.1655 - 1665.

16. J. B. Giménez, N. Martí, J. Ferrer and A. Seco, Methane recovery efficiency in a submerged anaerobic membrane bioreactor (SAnMBR) treating sulphate-rich urban wastewater: Evaluation of methane losses with the effluent, Bioresource Technology, $2012,11867-72$.

17. C. L. Souza, C. A. L. Chernicharo and S. F. Aquino, Quantification of dissolved methane in UASB reactors treating domestic wastewater under different operating conditions, Water Science and Technology, 2011, 64(11), p.2259-2264.

18. J. Cookney, E. Cartmell, B. Jefferson and E. J. McAdam, Recovery of methane from anaerobic process effluent using poly-di-methyl-siloxane membrane contactors, Water Science and Technology, 2012, 65(4), p.604-610.

19. J. D. Vela, L. B. Stadler, K. J. Martin, L. Raskin, C. B. Bott and N. G. Love, Prospects for Biological Nitrogen Removal from Anaerobic Effluents during Mainstream Wastewater Treatment, Environmental Science \& Technology Letters, 2015, 2(9), p.234-244.

20. J. Cookney, A. McLeod, V. Mathioudakis, P. Ncube, A. Soares, B. Jefferson and E. J. McAdam, Dissolved methane recovery from anaerobic effluents using hollow fibre membrane contactors, Journal of Membrane Science, 2016, 502141 - 150.

21. RD 509/1996, BOE 77, https://www.boe.es/boe/dias/1996/03/29/pdfs/A1203812041.pdf, (accessed 03/30/2016).

22. Apha, Standard Methods for the Examination of Water and Wastewater, American Public Health Association, Washington D.C., USA, 1998. 
23. W. Zhou, Y. Sun, B. Wu, Y. Zhang, M. Huang, T. Miyanaga and Z. Zhang, Autotrophic denitrification for nitrate and nitrite removal using sulfur-limestone, Journal of Environmental Sciences, 2011, 23(11), p.1761 - 1769.

24. W. Zeng, L. Li, Y.-y. Yang, X.-d. Wang and Y.-z. Peng, Denitrifying phosphorus removal and impact of nitrite accumulation on phosphorus removal in a continuous anaerobicanoxic-aerobic (A2O) process treating domestic wastewater, Enzyme and Microbial Technology, 2011, 48(2), p.134 - 142.

25. L. H. P. Garbossa, J. A. Rodriguez, K. R. Lapa and E. Foresti, Journal, 2005. 


\title{
Chapter 4. Advanced denitrification of anaerobic treatment effluent of domestic wastewater by using wasted gas
}

\begin{abstract}
A pilot plant of denitritation was operated for more than five months treating domestic wastewater with high ammonium nitrogen concentration from anaerobic process under ambient temperature conditions (18 $\mathrm{o})$. The process consisted on one biofilter with $2 \mathrm{~h}$ of hydraulic retention time (HRT) for denitritation. To study the feasibility of the denitritation process, different synthetic nitrite concentrations were supplied to the anoxic reactor to simulate the effluent of a nitritation process. The present work investigates an advanced denitritation of wastewater using the organic matter and other alternative electron donors from an anaerobic treatment: methane and sulfide. The denitrifying bacteria were able to treat water at an inlet nitrite concentration of $75 \mathrm{mg} \mathrm{NO}{ }^{-}-\mathrm{N} / \mathrm{L}$ with removal efficiency of $92,9 \%$. When the inlet nitrite concentration was higher it was necessary to recirculate the gas obtained in the anoxic reactor to enhance the nitrite removal, achieving $98,3 \%$ of $\mathrm{NO}_{2}{ }^{-}$elimination efficiency.
\end{abstract}

Keywords: Denitritation • Domestic wastewater • Electron donor • Methane • Sulfide 


\section{INTRODUCTION}

The anaerobic treatment of wastewater has become the most used method for the effluents because its advantages over conventional activated sludge treatment. These include that energy balances are quite favorable due to the energy recovery as biogas instead of energy consumption, no energy requirement for aeration, minimum sludge production, low space requirements and a smaller footprint. On the contrary, it has some disadvantages such as process sensitivity, possible bad odors, long start-up period and to comply with discharge standards, effluent from anaerobic treatment require further treatment for the remaining chemical oxygen demand (COD) and especially for nitrogen and phosphorus because of its low pathogen and nutrient removal ${ }^{[1-5]}$.

The methane $\left(\mathrm{CH}_{4}\right)$ production in the anaerobic biodegradation of organic matter depends on the treatment efficiency. The solubility of methane in the liquid phase of anaerobic reactors raises with a decrease in the temperature, and increases its loss to the environment. The amount dissolved depends on the partial pressure of methane in the biogas, the temperature, and the degree of oversaturation ${ }^{[6,7]}$. Therefore, part of the $\mathrm{CH}_{4}$ produced is lost with the effluent and not available for energy production ${ }^{[2-4]}$. In addition to the reduction in recovered energy, the unintentional emission of $\mathrm{CH}_{4}$ in the atmosphere has the problem that it is a greenhouse gas with an effect on global warning 21 times stronger than carbon dioxide ${ }^{[7-9]}$, thus the resultant fugitive methane emission is potentially sufficient to impose a negative process carbon footprint. Release of methane may impose a potential health and safety issue due to its low explosive limit (down to $5 \%)^{[10,11]}$. A post-treatment process will be required in order to avoid dissolved methane release to the atmosphere and to make anaerobic wastewater treatment a more eco-friendly technology ${ }^{[3,12]}$.

Sulfide $\left(\mathrm{H}_{2} \mathrm{~S}\right)$ production and emission is a well-known problem in anaerobic digestion, which causes corrosion of pipes, odor nuisance and health hazards because of its toxicity. Sulfide is mainly generated anaerobically by the reduction of sulfate in wastewater through the respiration of sulfate-reducing bacteria (SRB). Sulfate concentration, COD concentration and HRT are among the key factors identified to influence sulfide concentration, with higher sulfate and COD concentrations and longer HRT favoring higher sulfide production ${ }^{[10,11]}$.

The elimination of nitrogen compounds from wastewater is based on nitrification and denitrification. In the first step, nitrification, ammonium is oxidized into nitrite by ammoniumoxidizing bacteria $(\mathrm{AOB})$, and nitrite is oxidized into nitrate during the second step by nitrite 
oxidizing bacteria ${ }^{[13]}$. The second step is denitrification, where nitrate (formed in the nitrification step) is anoxically converted into nitrite, then into nitrous oxide, nitric oxide, and finally into nitrogen gas, according with this sequence:

$$
\mathrm{NH}_{4}^{+} \rightarrow \mathrm{NO}_{2}^{-} \rightarrow \mathrm{NO}_{3}^{-} \rightarrow \mathrm{NO}_{2}^{-} \rightarrow \mathrm{NO} \rightarrow \mathrm{N}_{2} \mathrm{O} \rightarrow \mathrm{N}_{2}
$$

Denitrifying microorganisms are heterotrophic, and in anoxic conditions use nitrite or nitrate as final electron acceptors ${ }^{[14-16]}$. The presence of an organic carbon source is needed in heterotrophic denitrification. When not enough COD is present in the wastewater being treated for denitrification to occur, for example in wastewaters with a low COD/N ratio, or because of high COD consumption in previous steps such as nitrification, the addition of external carbon source is required to be added in the system to achieve effective heterotrophic denitrification ${ }^{[17,18]}$. Operational costs of the biological nitrogen removal process are to a great extent related to the oxygen and organic matter requirements for nitrification and denitrification, respectively. Several new processes and operational strategies have arisen during the last years in order to reduce these costs. One of these is the shortcut to biological nitrogen removal. This process is based on the fact that, since nitrite is an intermediary compound in nitrification and denitrification, it will be convenient to produce a partial nitrification up to nitrite and then denitrification starting from this nitrite, as indicates the following sequence:

$$
\mathrm{NH}_{4}^{+} \rightarrow \mathrm{NO}_{2}^{-} \rightarrow \mathrm{NO} \rightarrow \mathrm{N}_{2} \mathrm{O} \rightarrow \mathrm{N}_{2}
$$

The nitritation/denitritation process results in savings in oxygen demands during nitrification, requires less carbon source, leading to a reduction of the organic matter requirements in the denitrification process and a decrease in surplus sludge production ${ }^{[14-16,18]}$.

Denitrification process requires electron donors like organic carbon sources for the heterotrophic microbial reaction. However, the content of readily biodegradable substrate in wastewater is very often the limiting factor for complete denitrification even at relatively high $\mathrm{C} / \mathrm{N}$ ratios. In these cases, external carbon sources such as methanol need to be supplied to achieve complete heterotrophic denitrification, thus increasing the operating cost of treatment because of the acquisition of chemicals and the possible production of additional sludge ${ }^{[19-21]}$.

To lower the costs of denitrification, the search for electron donors produced during the wastewater treatment processes has deserved special attention. Methane and sulfide could be interesting alternative electron donors for the denitrification process ${ }^{[22-24]}$. The literature presents options in which the biogas outlet line generated from an UASB reactor was connected 
to the anoxic reactor. Thus, the biogas supplied could be used in the denitrification process. Because of biogas is produced in the anaerobic treatment plants, this technology can produce low-cost and efficient electron donors readily useable for denitrification.

What is proposed in this work is the use of methane and sulfide present in the wastewater from the anaerobic treatment, and not the biogas line directly. Methane and sulfide, dissolved and oversaturated in the water, by entering in the anoxic reactor are going to be desorbed, passing to the gaseous state and thus being used by denitrifying bacteria. Using these compounds for denitritation would make nitrogen removal less expensive than introducing chemicals.

If this proceeding is not enough to remove the nitrite from the wastewater, it is proposed the recirculation of the gas obtained in the top of the anoxic reactor to the lower part of itself. In this way, the remained electron donors present in the waste gas, not previously used for denitrify, have another opportunity to be used in the process.

The process combining both anaerobic treatment and nitrogen removal allows partial conversion of organic matter into a valuable energy, while respecting the environmental constraints as regards nitrogen and energy costs are reduced. The denitrification process displayed can simultaneously convert nitrate, methane and sulfide from the wastewater into dinitrogen gas, carbon dioxide and sulfate, respectively, using anoxic condition.

The objective of this research was to study the feasibility of the partial denitrification process of high ammonium nitrogen concentration wastewater using alternative electron donors present in the anaerobic membrane bioreactor (AnMBR) effluent: $\mathrm{OM}$ and $\mathrm{CH}_{4}$ and $\mathrm{S}^{2-}$. For high nitrite concentrations in the feeding, it was study the possibility of recirculate the waste gas from the anoxic reactor with the aim of reuse the electron donors not previously used for denitrify.

\section{MATERIALS AND METHODS}

\subsection{Experimental Setup}

The experimental study of partial denitrification process consists of one anoxic fixed-bed bioreactor built in glass PVC. The bioreactor, an upflow cylindrical column, had a height of 2.8 $\mathrm{m}$, a diameter of $0.15 \mathrm{~m}$ and a working volume was of approximately $20 \mathrm{~L}$. A diagram of the bioreactor is shown in Figure 1. In order to serve as support for the medium, the reactor was filled with Filtralite ${ }^{\circledR}$ with the following characteristics: effective size, $3.5 \mathrm{~mm}$; bulk density, 825 
$\mathrm{kg} / \mathrm{m}^{3}$; particle density, $1450 \mathrm{~kg} / \mathrm{m}^{3}$; particle porosity, $46 \%$. The reactor was fed with the reject water of an AnMBR that treated domestic wastewater under psychrophilic conditions in a previous stage where the major COD was converted into biogas ${ }^{[5]}$, therefore, the AnMBR produced effluents with low levels of readily biodegradable organic matter. Also, a synthetic nitrite stream fed the bioreactor simulating the effluent of a nitritation process. $\mathrm{NaNO}_{2}$ solution was pumped continuously by a diaphragm metering pump and it was used as the nitrite source. The inoculum was a mix of anoxic sludge and anaerobic digested sludge, taken from the wastewater treatment plant of Valladolid (Spain). The biofilter was equipped with measurement systems for pressure, gas flow and oxidation-reduction potential (ORP).

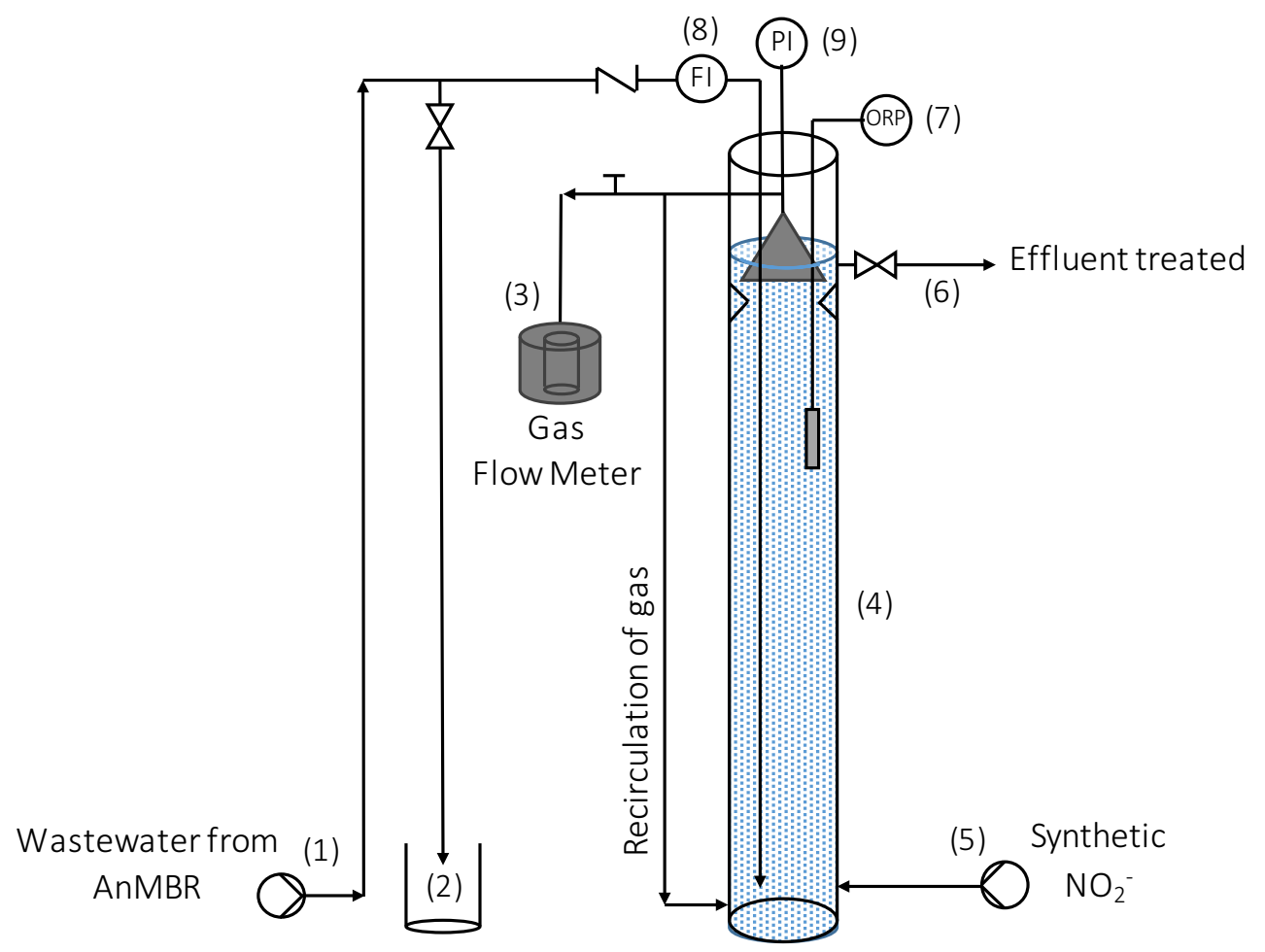

Figure 1: Scheme of the denitrification/denitritation plant. (1) Filling pump, supplies the wastewater to be treated, (2) Tank with the water that does not enter in process. (3) Gas collection chamber, (4) bioreactor, (5) Pump that supply the synthetic $\mathrm{NO}_{2}{ }^{-}$solution, (6) Current of the effluent treated, (7) oxidation/reduction potential meter, (8) Flow indicator, (9) Pressure gauge.

\subsection{Feeding Characteristics}

The studied reactor was fed with the effluent from an AnMBR treating domestic wastewater and the synthetic nitrite stream, to simulate the recirculation of the aerobic treatment effluent. The AnMBR pilot plant is explained in detail in a previous work ${ }^{[5]}$. Typical composition of the wastewater used as inlet to the continuous flow denitritation reactor is given in Table 1. When 
the AnMBR effluent was sampled, the sulfide contained in the wastewater was oxidized to sulfate, and by chromatographic techniques this compound could be determined. In the inlet stream (from anaerobic treatment), sulfur is the corresponding amount of sulfide oxidation without quantify the oversaturation, so the real value for sulfide was higher.

Table 1: Average composition of the wastewater from AnMBR before treatment.

\begin{tabular}{ccccccc}
$\begin{array}{c}\mathrm{sCOD} \\
\left(\mathrm{mg} \mathrm{O}_{2} / \mathrm{L}\right)\end{array}$ & $\begin{array}{c}\mathrm{TKN} \\
(\mathrm{mg} \mathrm{N} / \mathrm{L})\end{array}$ & $\begin{array}{c}\mathrm{NH}_{4}{ }^{+} \\
(\mathrm{mg} \mathrm{N} / \mathrm{L})\end{array}$ & $\begin{array}{c}\mathrm{NO}_{3}{ }^{-} \\
(\mathrm{mg} \mathrm{N} / \mathrm{L})\end{array}$ & $\begin{array}{c}\mathrm{NO}_{2}^{-} \\
(\mathrm{mg} \mathrm{N} / \mathrm{L})\end{array}$ & $\begin{array}{c}\mathrm{SO}_{4}{ }^{2-} \\
(\mathrm{mg} \mathrm{S} / \mathrm{L})\end{array}$ & $\begin{array}{c}\text { sol P } \\
(\mathrm{mg} \mathrm{P} / \mathrm{L})\end{array}$ \\
\hline 113.2 & 108.6 & 94.3 & 0.0 & $50-75-90$ & 8.4 & 10.9
\end{tabular}

\subsection{Operating Scheme}

The anoxic bioreactor was operated for a period of five months with an inlet flow of $10 \mathrm{~L} / \mathrm{h}$. Considering the effective volume of the reactor it can be assumed a corresponding HRT of approximately 2 hours throughout the experiment. Temperature in the plant was maintained under ambient conditions $(18 \stackrel{\circ}{\circ})$ using a fan coil unit in the laboratory. Four stages with different operating conditions were studied.

The feed concentrations of nitrite were used with the intention of simulate the effluent of a nitritation process. The nitritation process would oxidize the $\mathrm{NH}_{4}{ }^{+}$available in the feeding wastewater, that looking the Table 3 its concentration varied from 80 to $110 \mathrm{mg} \mathrm{NH}{ }_{4}{ }^{+} \mathrm{N} / \mathrm{L}$. Stoichiometrically, the $\mathrm{NH}_{4}{ }^{+}$oxidized would imply a nitrite concentration between 62 and $85 \mathrm{mg}$ $\mathrm{NO}_{2}-\mathrm{N} / \mathrm{L}$ approximately. To work with a security range, it was introduced up to $95 \mathrm{mg} \mathrm{NO}{ }^{-}-\mathrm{N} / \mathrm{L}$. Table 2 shows the stages of operating. The difference between the first three stages was the nitrite feeding concentration. 50, 75 and $90 \mathrm{mg} \mathrm{NO}_{2}{ }^{-} \mathrm{N} / \mathrm{L}$ were the inlet nitrite concentration for stages 1, 2 and 3 respectively. In stage 4, a new stream was added to the denitrification reactor. The gas obtained from the anoxic reactor was recirculated to reintroduce in the process electron donors not previously used for denitrify.

Table 2: Stages of operation.

\begin{tabular}{cl} 
Stage & $\mathrm{NO}_{2}{ }^{-}$inlet concentration \\
\hline 1 & $50 \mathrm{mg} \mathrm{NO}_{2}{ }^{-} \mathrm{N}$ \\
2 & $75 \mathrm{mg} \mathrm{NO}_{2}{ }^{-} \mathrm{N}$ \\
3 & $90 \mathrm{mg} \mathrm{NO}_{2}{ }^{-} \mathrm{N}$ \\
4 & $95 \mathrm{mg} \mathrm{NO}_{2}{ }^{-} \mathrm{N}$ with gas recirculation
\end{tabular}




\subsection{Analytical Methods}

Samples of wastewater were collected periodically before and after the denitritation process. The concentration of nitrite, nitrate and soluble phosphorus were measured by High Performance Liquid Chromatography (HPLC). Ammonium concentration was determined using an ammonia-selective electrode: Orion, model 9512HPBNWP. The analyses of Chemical Oxygen Demand (COD), Total Kjeldahl Nitrogen (TKN) as well as total and volatile suspended solids (TSS, VSS) were determined according to the Standard methods for examination of water and wastewater suggested by the manual APHAAWWA-WPCF ${ }^{[25]}$. The measurement of dissolved oxygen concentration was determined with an oximeter WTW, model oxi 330/SET and a dissolved oxygen probe CeliOx 325. Gas production was measured volumetrically by water displacement, and its composition in terms of methane, carbon dioxide, nitrogen, oxygen, hydrogen sulfide and hydrogen was determined by gas chromatography (GC) (Varian CP-3800). Pressure, temperature and oxidation reduction potential (ORP) were measured by using sensors and probes.

\section{RESULTS AND DISCUSSION}

The reactor was operating during more than five months under the conditions previously described in Table 2. The feasibility of using the reduced compounds of the water from an AnMBR as electron donors for denitritation was evaluated at different $\mathrm{NO}_{2}{ }^{-}$ concentrations in the feed stream (stages 1-3). As consequence, raising the $\mathrm{NO}_{2}{ }^{-}$ concentration in the feeding, the nitrogen loading rate (NLR) was increased from $0.57 \mathrm{~kg}$ $\mathrm{N}-\mathrm{NO}_{2}{ }^{-} / \mathrm{m}^{3} \mathrm{~d}$ in the first stage to $1.03 \mathrm{~kg} \mathrm{~N}-\mathrm{NO}_{2}{ }^{-} / \mathrm{m}^{3} \mathrm{~d}$ in the stage 3 . An HRT of 2 hours was remained during all the research. The anaerobically pretreated domestic sewage presented a low COD/NO${ }_{2}{ }^{-} \mathrm{N}$ ratio, specifically 1.87 in the stage 1 , and $1.47,1.30$ and 1.32 for the stages 2, 3 and 4, respectively. Table 3 summarizes the average concentrations of the main parameters in the inlet and outlet of the denitritation process for the different stages of operation. 
Table 3: Summary of the parameters average for different $\mathrm{NO}_{2}{ }^{-}$concentrations inlet on denitritation.

\begin{tabular}{|c|c|c|c|c|c|c|c|c|}
\hline & & $\begin{array}{c}\mathrm{sCOD} \\
\left(\mathrm{mg} \mathrm{O}_{2} / \mathrm{L}\right)\end{array}$ & $\begin{array}{c}\text { TKN } \\
(\mathrm{mg} \mathrm{N} / \mathrm{L})\end{array}$ & $\begin{array}{c}\mathrm{NH}_{4}^{+} \\
(\mathrm{mg} \mathrm{N} / \mathrm{L})\end{array}$ & $\begin{array}{c}\mathrm{NO}_{3}{ }^{-}-\mathrm{N} \\
(\mathrm{mg} \mathrm{N} / \mathrm{L})\end{array}$ & $\begin{array}{c}\mathrm{NO}_{2}{ }^{-}-\mathrm{N} \\
(\mathrm{mg} \mathrm{N} / \mathrm{L})\end{array}$ & $\begin{array}{c}\text { sol S } \\
(\mathrm{mg} \mathrm{S} / \mathrm{L})\end{array}$ & $\begin{array}{c}\text { sol P } \\
(\mathrm{mg} \mathrm{P} / \mathrm{L})\end{array}$ \\
\hline \multirow{2}{*}{1} & Inlet & 97,7 & 114.0 & 79.0 & 0.0 & 52.2 & 12.8 & 8.6 \\
\hline & Outlet & 60.6 & 86.4 & 77.5 & 0.0 & 2.5 & 21.3 & 8.8 \\
\hline \multirow{2}{*}{2} & Inlet & 109.9 & 110.7 & 97.6 & 0.0 & 74.7 & 7.2 & 11.3 \\
\hline & Outlet & 65.1 & 109.8 & 95.9 & 0.0 & 5.3 & 29.2 & 11.3 \\
\hline \multirow{2}{*}{3} & Inlet & 119.7 & 98.5 & 92.4 & 0.0 & 92.2 & 5.8 & 11.8 \\
\hline & Outlet & 76.6 & 100.5 & 86.0 & 0.0 & 21.0 & 24.6 & 9.8 \\
\hline \multirow{2}{*}{4} & Inlet ${ }^{a}$ & 125.5 & 111.0 & 108.0 & 0.0 & 95.0 & 7.8 & 11.7 \\
\hline & Outlet & 79.3 & 112.4 & 84.2 & 0.0 & 1.6 & 20.0 & 9.1 \\
\hline
\end{tabular}

As it can be seen in Table 3, the results indicated nitrite elimination efficiencies of $95.1 \%$ and 92.9\% when the inlet concentration was 50 and $75 \mathrm{mg} \mathrm{NO}_{2}^{-} \mathrm{-N} / \mathrm{L}$ (stages 1 and 2), respectively. In the stage 3, when the feed was $90 \mathrm{mg} \mathrm{NO}{ }^{-}-\mathrm{N} / \mathrm{L}, 77 \%$ of nitrites were eliminated obtaining around $21 \mathrm{mg} \mathrm{NO}{ }_{2}^{-} \mathrm{N} / \mathrm{L}$ in the outlet. The $\mathrm{NO}_{2}{ }^{-} \mathrm{N}$ concentration in the effluent increased while the removal efficiency decreased due to the increase in the NLR by raising the influent $\mathrm{NO}_{2}{ }^{-} \mathrm{N}$ concentration.

During the stages 1,2 and 3 , the gas composition at the outlet of the denitritation process contained mainly $\mathrm{N}_{2}$ and $\mathrm{CH}_{4}$ (58\% and $37 \%$, respectively). All the sulfide from the feed water were used for the nitrites reduction because there was no $\mathrm{H}_{2} \mathrm{~S}$ in the gas phase.

To improve the denitritation process when the nitrite feeding concentration was about 90 mg NO${ }_{2}^{-}-\mathrm{N} / \mathrm{L}$, it was proceeded to recirculate the gas collected in the top of the reactor to the lower part (stage 4). Thus, methane desorption (initially oversaturated) was favored and denitrifying bacteria were able to use it as electron donor. Fortunately, this performance was successful, achieving around $98.3 \%$ of nitrite elimination efficiency after the denitrifying process when the NLR was $1.09 \mathrm{~kg} \mathrm{~N} / \mathrm{m}^{3} \mathrm{~d}$.

Figure 2 shows the concentrations of $\mathrm{NO}_{2}-\mathrm{N}$ and $\mathrm{COD}$ in the influent and effluent in time. The graph shows a high variability in the feeding COD concentrations during all the stages of the experiment due to the typical fluctuations in actual domestic sewage. In Figure 3, it is represented the evolution of nitrite before and after denitritation and the removal percentage of this compound in each period studied, with their corresponding standard deviation. In the stage 3 , it can be seen the accumulation of nitrite at the end of the process, revealing a process 
limitation to remove nitrite when the inlet concentration was $90 \mathrm{mg} \mathrm{NO}{ }_{2}^{-} \mathrm{N} / \mathrm{L}$, while in the rest of stages it is clear its almost total elimination.

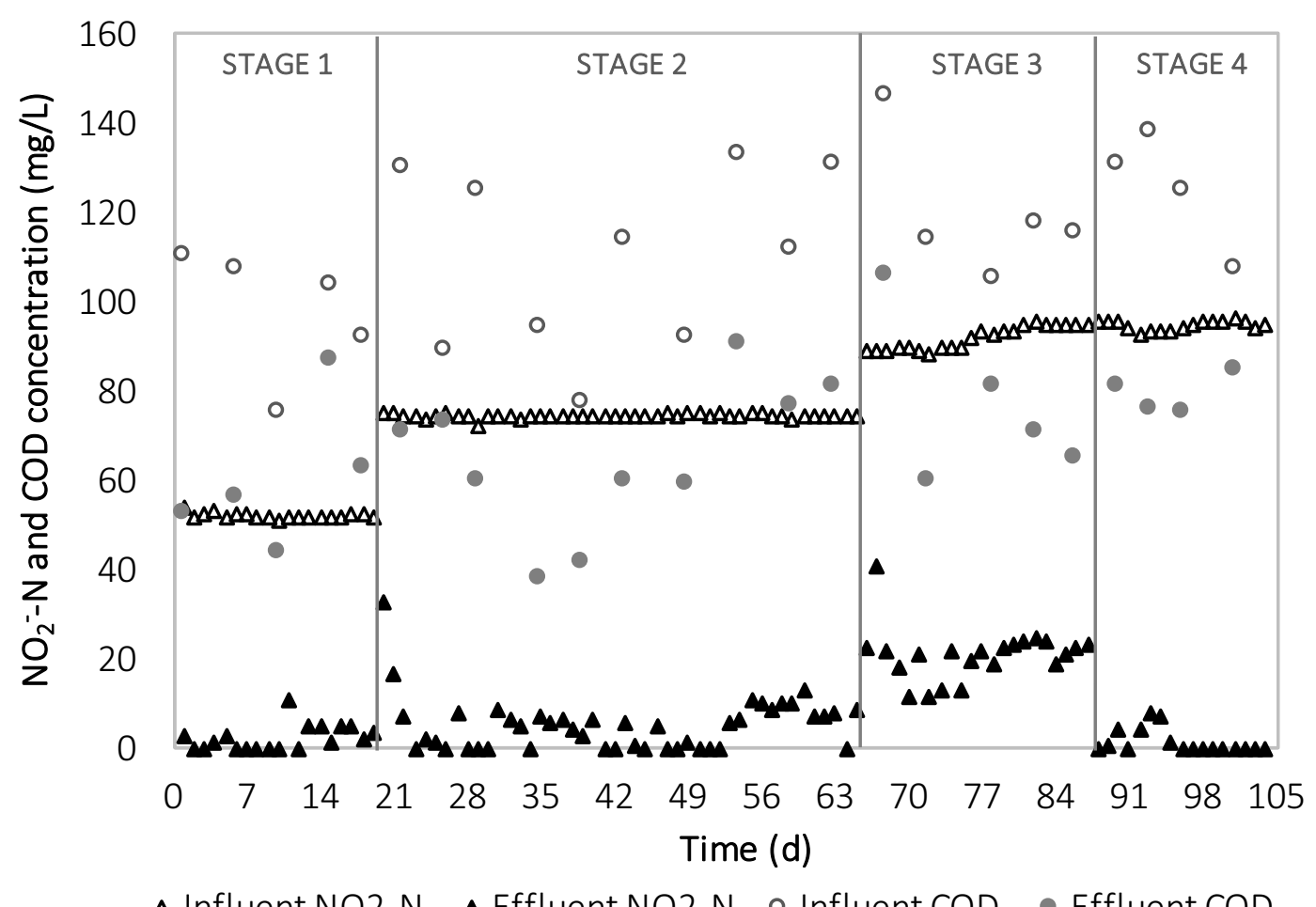

Figure 2: Concentrations of $\mathrm{NO}_{2}^{-}-\mathrm{N}$ and $\mathrm{COD}$ in the influent and effluent in time.

During the anoxic process, the organic matter showed significant decreases between $36 \%$ and $41 \%$, as it can be seen in the column of soluble COD from the Table 3 and in the Figure 3. These values of COD removed correspond to the biological oxygen demand (BOD) available in the feeding wastewater. This phenomenon can be explained because the organic matter is one of the electron donors used by the bacteria to denitrify. The TKN, whose $\mathrm{NH}_{4}{ }^{+}$composition exceeds $70 \%$, did not vary during the treatment, because nitritation is unlikely to have occurred due to the low DO levels in the denitritation process. Comparing the concentration of $\mathrm{SO}_{4}{ }^{2-}$ in the influent and effluent of the process, it was increased due to the oxidation of the $\mathrm{H}_{2} \mathrm{~S}$ available in wastewater from anaerobic treatment, to $\mathrm{SO}_{4}{ }^{2-}$. No modification of soluble phosphorus was observed during the process. 


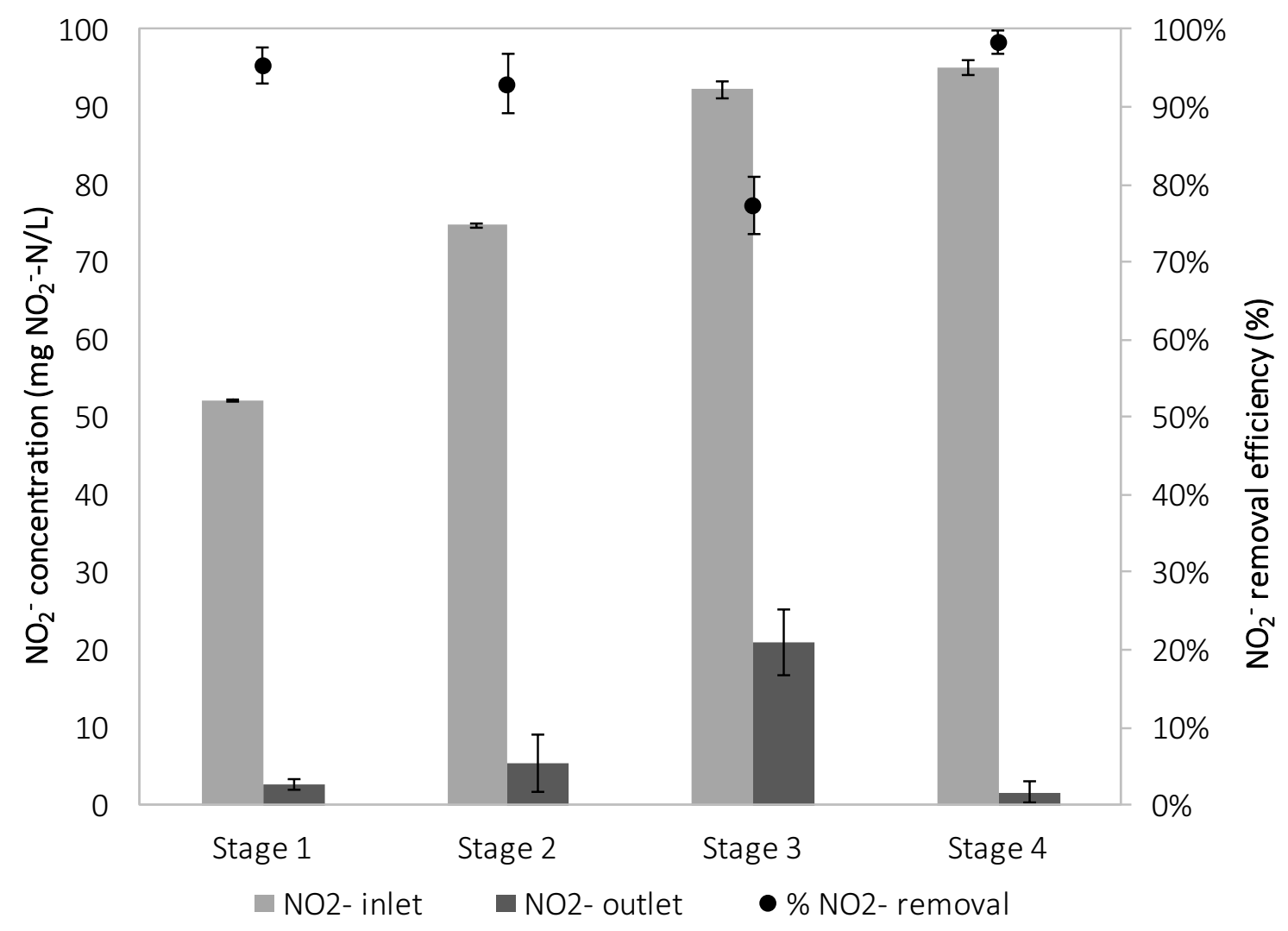

Figure 3: Evolution of $\mathrm{NO}_{2}^{-}$before and after denitritation and percentage of $\mathrm{NO}_{2}^{-}$removal efficiency.

Knowing the $\mathrm{OM}, \mathrm{H}_{2} \mathrm{~S}$ and $\mathrm{CH}_{4}$ available in wastewater, and the stoichiometric ratios between electron donors and acceptors (Table 4), it was possible to determine the intervention percentage of each electron donor. The biogas composition of the AnMBR with respect to $\mathrm{CH}_{4}$ and $\mathrm{H}_{2} \mathrm{~S}$, is $84 \%$ and $0.2 \%$ respectively. By Henry's Law at the operational temperature, it can be obtained the theoretical concentration of that compounds dissolved in the effluent of anaerobic treatment, therefore the inlet for the denitritation process. The theoretical values of dissolved methane and sulfide calculated were $22.2 \mathrm{mg} \mathrm{CH}_{4} / \mathrm{L}$ and $8.9 \mathrm{mg} \mathrm{H}_{2} \mathrm{~S} / \mathrm{L}$. Moreover, dissolved methane and sulfide oversaturation in the anaerobic effluent was observed ${ }^{[5]}$, so a higher concentration of these alternative electron donors was available in the wastewater to be used of denitrify.

Table 4: Average parameters for different $\mathrm{NO}_{2}{ }^{-} / \mathrm{NO}_{3}{ }^{-}$ratios on denitrification.

\begin{tabular}{lcc}
\multicolumn{1}{c}{ Ratios } & $\mathrm{NO}_{2}^{-}$ & $\mathrm{NO}_{3}^{-}$ \\
\hline $\mathrm{OM}(\mathrm{mg} \mathrm{COD} / \mathrm{mg} \mathrm{N})$ & 2.4 & 4.0 \\
$\mathrm{~S}^{2-}(\mathrm{mg} \mathrm{S} / \mathrm{mg} \mathrm{N})$ & 1.4 & 2.3 \\
$\mathrm{CH}_{4}(\mathrm{mg} \mathrm{CH} / \mathrm{mg} \mathrm{N})$ & 0.4 & 0.7
\end{tabular}


Methane was by far the main electron donor used (65\%) followed by organic matter (22\%). Sulfide was the electron donor less used $(13 \%)$ due to their lower content in the water from AnMBR. As reported in the literature ${ }^{[21,26]}$, there are indications that denitrification occurs more easily by using sulfur compounds than methane. It is suggested that denitrification firstly occurs by using organic matter and sulfide present in the wastewater after anaerobic treatment. Then, because of the activity of methanotrophic microorganisms is lower than the autotrophic denitrifiers, after all sulfide electrons were consumed, the denitritation with methane started.

Methane and sulfide used as electron donors in denitrification process have several advantages when comparing with other alternatives such as the addition of methanol or acetate. The first two compounds are low-cost sources that can be suitable in the nitrogen removal from wastewater since that they can be generated onsite by the anaerobic digestion of sludge in the WWTP ${ }^{[23,27]}$. The process of methane oxidation coupled to denitrification can be applied for nitrogen pollution control, and to offset eutrophication and atmospheric methane concentrations simultaneously ${ }^{[28]}$.

This process developed was a part of an overall treatment plan where the $\mathrm{NO}_{2}$, organic matter, $\mathrm{CH}_{4}$ and $\mathrm{H}_{2} \mathrm{~S}$ were removed. For the full treatment, an aerobic reactor for nitritation was necessary, where $\mathrm{NH}_{4}{ }^{+}$was converted into $\mathrm{NO}_{2}{ }^{-}$, and took place the oxidation of the residual organic matter, achieving COD removal efficiencies higher than $80 \%$.

\section{CONCLUSIONS}

In order to treat effectively wastewater after anaerobic treatment, where most of the COD has been removed, denitritation process using alternative electron donors present in the water was investigated. The results of this study demonstrated that the denitritation process presented in this work was able to remove around $95 \%$ and $93 \%$ of nitrite when the inlet was $50 \mathrm{mg} \mathrm{NO}{ }^{-}-\mathrm{N} / \mathrm{L}$ and $75 \mathrm{mg} \mathrm{NO}{ }^{-}-\mathrm{N} / \mathrm{L}$ from a simulated recirculation of aerobic treatment effluent in 2 hours of HRT. For high inlet concentrations of nitrite, recirculation of the gas collected in the anoxic reactor was a successful solution, thus achieving a nitrite removal efficiency upper than $98 \%$ when the nitrite concentration in the feed was $95 \mathrm{mg} \mathrm{NO}{ }_{2}^{-}-\mathrm{N} / \mathrm{L}$.

Specifically, denitritation is a feasible process for the simultaneous removal of $\mathrm{NO}_{2}^{-}, \mathrm{OM}, \mathrm{CH}_{4}$ and $\mathrm{H}_{2} \mathrm{~S}$ for actual wastewater and the recirculation of the gas from the anoxic reactor is an efficacious system to enhance the nitrites removal. 


\section{ACKNOWLEDGEMENTS}

The authors thank the company Cadagua S.A., the European Regional Development Fund, and the project IPT-2011-1078-310000, and the INNPACTO 2011 program of the Ministry of Economy and Competitiveness for the technical and financial support. 


\section{References}

1. J. A. Álvarez, E. Armstrong, J. Presas, M. Gómez and Soto, Performance of a UASBDigester System Treating Domestic Wastewater, Environmental Technology, 2004, 25(10), p.1189-1199.

2. W. M. K. R. T. W. Bandara, T. Kindaichi, H. Satoh, M. Sasakawa, Y. Nakahara, M. Takahashi and S. Okabe, Anaerobic treatment of municipal wastewater at ambient temperature: Analysis of archaeal community structure and recovery of dissolved methane, Water Research, 2012, 46(17), p.5756-5764.

3. J. B. Giménez, N. Martí, J. Ferrer and A. Seco, Methane recovery efficiency in a submerged anaerobic membrane bioreactor (SAnMBR) treating sulphate-rich urban wastewater: Evaluation of methane losses with the effluent, Bioresource Technology, 2012, 11867-72.

4. C. Kampman, T. L. G. Hendrickx, F. A. Luesken, T. A. van Alen, H. J. M. Op den Camp, M. S. M. Jetten, G. Zeeman, C. J. N. Buisman and H. Temmink, Enrichment of denitrifying methanotrophic bacteria for application after direct low-temperature anaerobic sewage treatment, Journal of Hazardous Materials, 2012, 227-228164-171.

5. J. Gouveia, F. Plaza, G. Garralon, F. Fdz-Polanco and M. Peña, A novel configuration for an anaerobic submerged membrane bioreactor (AnSMBR). Long-term treatment of municipal wastewater under psychrophilic conditions, Bioresource Technology, 2015, 198510-519.

6. W. M. K. R. T. W. Bandara, H. Satoh, M. Sasakawa, Y. Nakahara, M. Takahashi and S. Okabe, Removal of residual dissolved methane gas in an upflow anaerobic sludge blanket reactor treating low-strength wastewater at low temperature with degassing membrane, Water Research, 2011, 45(11), p.3533 - 3540.

7. N. Matsuura, M. Hatamoto, H. Sumino, K. Syutsubo, T. Yamaguchi and A. Ohashi, Recovery and biological oxidation of dissolved methane in effluent from UASB treatment of municipal sewage using a two-stage closed downflow hanging sponge system, Journal of Environmental Management, 2015, 151200-209.

8. Intergovernmental Panel on Climate Change (IPCC), Fourth Assessment Report: Climate Change 2007, Available from: http://www.ipcc.ch/publications and_data/ar4/wg1/en/ch2s2-10-2.html, 2007.

9. J. Cookney, E. Cartmell, B. Jefferson and E. J. McAdam, Recovery of methane from anaerobic process effluent using poly-di-methyl-siloxane membrane contactors, Water Science and Technology, 2012, 65(4), p.604-610. 
10. G. Jiang, O. Gutierrez, K. R. Sharma and Z. Yuan, Effects of nitrite concentration and exposure time on sulfide and methane production in sewer systems, Water Research, 2010, 44(14), p.4241-4251.

11. J. Sun, S. Hu, K. R. Sharma, H. Bustamante and Z. Yuan, Impact of reduced water consumption on sulfide and methane production in rising main sewers, Journal of Environmental Management, 2015, 154307-315.

12. M. Hatamoto, H. Yamamoto, T. Kindaichi, N. Ozaki and A. Ohashi, Biological oxidation of dissolved methane in effluents from anaerobic reactors using a down-flow hanging sponge reactor, Water Research, 2010, 44(5), p.1409-1418.

13. M. Hatamoto, K. Ohtsuki, N. Maharjan, S. Ono, K. Dehama, K. Sakamoto, M. Takahashi and T. Yamaguchi, Performance evaluation of the sulfur-redox-reaction-activated upflow anaerobic sludge blanket and down-flow hanging sponge anaerobic/anoxic sequencing batch reactor system for municipal sewage treatment, Bioresource Technology, 2016, 204171 - 176.

14. G. Ciudad, O. Rubilar, P. Muñoz, G. Ruiz, R. Chamy, C. Vergara and D. Jeison, Partial nitrification of high ammonia concentration wastewater as a part of a shortcut biological nitrogen removal process, Process Biochemistry, 2005, 40(5), p.1715-1719.

15. G. Ruiz, D. Jeison, O. Rubilar, G. Ciudad and R. Chamy, Nitrification-denitrification via nitrite accumulation for nitrogen removal from wastewaters, Bioresource Technology, 2006, 97(2), p.330-335.

16. S. Aslan and M. Dahab, Nitritation and denitritation of ammonium-rich wastewater using fluidized-bed biofilm reactors, Journal of Hazardous Materials, 2008, 156(1-3), p.56-63.

17. Y. Fernández-Nava, E. Marañón, J. Soons and L. Castrillón, Denitrification of high nitrate concentration wastewater using alternative carbon sources, Journal of Hazardous Materials, 2010, 173(1-3), p.682 - 688.

18. S. Malamis, E. Katsou, S. D. Fabio, D. Bolzonella and F. Fatone, Biological nutrients removal from the supernatant originating from the anaerobic digestion of the organic fraction of municipal solid waste, Critical Reviews in Biotechnology, 2014, 34(3), p.244257.

19. I. Manconi, A. Carucci and P. Lens, Combined removal of sulfur compounds and nitrate by autotrophic denitrification in bioaugmented activated sludge system, Biotechnology and Bioengineering, 2007, 98(3), p.551-560. 
20. M. Waki, H. Yokoyama, A. Ogino, K. Suzuki and Y. Tanaka, Nitrogen removal from purified swine wastewater using biogas by semi-partitioned reactor, Bioresource Technology, 2008, 99(13), p.5335-5340.

21. J. L. R. Pantoja Filho, M. H. R. Z. Damianovic, D. F. Fonseca and E. Foresti, Nitrogen and residual organic matter removal from anaerobic reactor effluent in a fixed-bed reactor with biogas for denitrification, Journal of Chemical Technology \& Biotechnology, 2015, 90(12), p.2227-2233.

22. C. Costa, C. Dijkema, M. Friedrich, P. García-Encina, F. Fernández-Polanco and A. J. M. Stams, Denitrification with methane as electron donor in oxygen-limited bioreactors, Applied Microbiology and Biotechnology, 2000, 53(6), p.754-762.

23. S. Islas-Lima, F. Thalasso and J. Gómez-Hernandez, Evidence of anoxic methane oxidation coupled to denitrification, Water Research, 2004, 38(1), p.13-16.

24. J. Rodríguez Victoria and E. Foresti, A novel aerobic-anoxic biological filter for nitrogen removal from UASB effluent using biogas compounds as electron donors for denitrification, Revista Facultad de Ingeniería Universidad de Antioquia, 201172 - 80.

25. Apha, Standard Methods for the Examination of Water and Wastewater, American Public Health Association, Washington D.C., USA, 1998.

26. Garbossa, J. A. Rodriguez, K. R. Lapa and E. Foresti, Journal.

27. F.-y. Sun, W.-y. Dong, M.-f. Shao, X.-m. Lv, J. Li, L.-y. Peng and H.-j. Wang, Aerobic methane oxidation coupled to denitrification in a membrane biofilm reactor: Treatment performance and the effect of oxygen ventilation, Bioresource Technology, 2013, 1452 9.

28. J. Zhu, Q. Wang, M. Yuan, G.-Y. A. Tan, F. Sun, C. Wang, W. Wu and P.-H. Lee, Microbiology and potential applications of aerobic methane oxidation coupled to denitrification (AME-D) process: A review, Water Research, 2016, 90203 - 215. 


\title{
Chapter 5. \\ Nitrogen removal in domestic wastewater. Effect of the nitrate recycling and the $\mathrm{COD} / \mathrm{N}$ ratio.
}

\begin{abstract}
A denitrification/nitrification pilot plant was designed, built and operated to treat the effluent of an anaerobic reactor. The plant was operated to examine the effect of the nitrate recycling and the $\mathrm{COD} / \mathrm{N}$ ratio on the nitrogen and the remaining organic matter removal. The system consisted of a two stages treatment process: anoxic and aerobic. The hydraulic retention time (HRT) of the system was $2 \mathrm{~h}$ for the anoxic bioreactor and $4 \mathrm{~h}$ for the aerobic one. The increase in the nitrate recycling ratio did not suppose a significant improvement in the nitrogen removal due to the insufficient carbon source. The wastewater to be treated had a $\mathrm{C} / \mathrm{N}$ ratio of 1.1 showing a lack of organic carbon. The addition of methanol was a key point in the denitrification process employed as a model for the traditional wastewater by-pass in the WWTP. The maximum nitrogen and organic matter removal ( $84.7 \%$ and $96 \%$, respectively) was achieved with a nitrate recycling ratio of $600 \%$ and a $\mathrm{C} / \mathrm{N}$ of 8.25 , adjusted by methanol addition.
\end{abstract}

Keywords: Biological nutrient removal $(\mathrm{BNR}) \bullet \mathrm{C} / \mathrm{N}$ ratio $\bullet$ Denitrification $\bullet$ Nitrification • Organic matter 


\section{INTRODUCTION}

Wastewater treatment plants (WWTPs) are defined currently to remove particulate and dissolved organic fractions and, in more sensitive areas, nitrogen and phosphorus compounds. The most conventional well-known intensive system to treat domestic wastewater is the activated sludge process ${ }^{[1]}$. However, the anaerobic treatment of wastewater has become the most used method for processing effluents because its advantages over conventional activated sludge treatment. It requires low energy consumption, while it provides low wastage of biological solids, and transforms the organic matter into valuable biogas ${ }^{[2]}$. Among the disadvantages of the anaerobic treatment, post treatments are necessary in order to achieve discharge standards.

According to the Official Spanish Bulletin (BOE), the characteristic parameters of the activity, its emission limit values and reference measurement methods for discharges from wastewater treatment plants derive from Directive 91/271/CEE transposed by RDL 11/1995, RD 509/1996 and RD 2116/1998. The requirements for discharges from WWTP are $125 \mathrm{mg} \mathrm{O} / \mathrm{L}$ for the chemical oxygen demand (COD) or a minimum reduction percentage of $75 \%$ (reduction in relation to the influent load), and $15 \mathrm{mg} \mathrm{N} / \mathrm{L}$ for the total nitrogen (TN) or a minimum reduction percentage between $70-80 \%{ }^{[3,4]}$.

In the last decade, increasingly stringent environmental requirements have been imposed on nutrients discharge in receiving waters, because excessive nutrients are considered the primary causes of eutrophication ${ }^{[5]}$. Most of the efforts have been focused on the development of new technologies capable of obtaining better effluent quality, with special attention to nitrogen removal and the reduction of treatment costs ${ }^{[6]}$. To control eutrophication in receiving water bodies, biological nutrient removal (BNR) of nitrogen has been widely used in wastewater treatment practice, both for the upgrade of existing wastewater treatment facilities and the design of new facilities ${ }^{[7]}$. BNR constitutes the most economical and sustainable technique to meet increasingly rigorous discharge requirements ${ }^{[8,9]}$.

BNR is achieved through two processes: nitrification and denitrification. In the nitrification process, under aerobic conditions, ammonium $\left(\mathrm{NH}_{4}{ }^{+}\right)$is converted to nitrite $\left(\mathrm{NO}_{2}{ }^{-}\right)$by the ammonium oxidizing bacteria (AOB). Then, nitrite is oxidized to nitrate $\left(\mathrm{NO}_{3}^{-}\right)$by the nitrite oxidizing bacteria ${ }^{[10]}$. Denitrification is an anoxic process of nitrate reduction into nitrite and then into molecular nitrogen gas $\left(\mathrm{N}_{2}\right)$, which is performed by a functional group of heterotrophs that use nitrite and/or nitrate as the electron acceptor in respiration. Denitrification process 
requires electron donors like organic carbon sources for the heterotrophic ${ }^{[8,9,11-13]}$. Although the conventional denitrification uses organic matter as electron donor for denitrify, denitrification using alternative electron donors, as methane and sulfide, have been experimentally applied to wastewaters for denitrification ${ }^{[13,14]}$.

There are different terms of denitrification such as pre-denitrification and postdenitrification depending on the order of nitrification and denitrification. In a postdenitrification configuration, wastewater is fed to a nitrification system prior to denitrification. This configuration leads usually to a total consumption of the COD before starting the denitrification process; therefore an exogenous carbon source should be supplied to carry out the post-anoxic denitrification ${ }^{[9,15]}$. In contrast, in most BNR systems, the anoxic stage is located upstream of the aerobic zone. Wastewater is fed directly to the denitrification system, supplying organic carbon to remove nitrite and nitrate that are recycled from the nitrification system. High denitrification rates can be achieved with the pre-anoxic regime given the supply of readily biodegradable carbon. However, it is accompanied with some disadvantages such as higher energy costs from mixed liquor recycle flows, dissolved oxygen (DO) return from the aerobic, and dilution of influent carbon ${ }^{[8,15]}$.

After anaerobic treatment, a nitrogen removal plant receives an influent containing mainly the residual soluble fraction of organic carbon present in domestic wastewater and a large fraction of the nitrogen. Therefore, the influent presents a low COD/N ratio, which is favorable to the nitrification stage but may be an obstacle for the denitrification step ${ }^{[1]}$.

The denitrification potential of wastewater is mainly governed by the availability of biodegradable organic carbon, commonly expressed as the $\mathrm{C} / \mathrm{N}$ ratio ${ }^{[6]}$. Therefore, the $\mathrm{C} / \mathrm{N}$ ratio of the influent is one of the most critical parameters that can affect directly the biological nitrogen removal efficiency. This occurs because different microorganisms populations compete for substrate causing fluctuation in effectiveness of organic and nitrogen removal [12, 16]. Theoretically, the stoichiometric requirement of organic substrate for denitrification is $2.86 \mathrm{~g}$ $\mathrm{COD} / \mathrm{g} \mathrm{N}$, considering the electron transmitting balance between organic substrate and $\mathrm{NO}_{3}$. But some studies demonstrated that $\mathrm{C} / \mathrm{N}$ values of approximately $6-11 \mathrm{~g}$ COD/g N could allow a proper nitrogen removal ${ }^{[6]}$. In the case of Kim et al. ${ }^{[15]}$, with a $\mathrm{C} / \mathrm{N}=8$ ratio, it was obtained an average denitrification efficiency around $72 \%$. Another example, Fu et al. ${ }^{[16]}$, achieved a nitrogen removal efficiency of $90.6 \%$ when the $\mathrm{C} / \mathrm{N}$ ratio was 9.3 .

The amount of biodegradable organic carbon of domestic wastewater after anaerobic treatment is limited and nitrogen removal is limited by the lack of bioavailable electron donors 
for heterotrophic denitrification ${ }^{[5,17]}$. Therefore, the addition of external carbon sources often becomes necessary for achieving high-efficiency BNR, especially for facilities with weak influent biological oxygen demand (BOD) and/or those facing strict effluent limits ${ }^{[5,18]}$. Methanol is the most commonly used electron donor, as a result of the higher denitrification efficiency, as indicated by the relatively lower methanol-to-nitrate ratio, lower cost, and broad availability in the market. The main disadvantage of using methanol is the safety issues associated with its transportation, handling, and storage. The use of methanol in commercial scale entails costs and the process may not be viable from an economic point of view. It has been estimated that an additional 25 to $31 \%$ of the capital construction cost for methanol storage, pumping, and delivery systems is required to meet the safety standards over the use of a non-flammable, nonhazardous product ${ }^{[5,19]}$.

One of the most effective methods to increase the organic matter concentration of the influent without the addition of external organic substrates is achieved by mixing a fraction of the influent to the anaerobic reactor with the effluent of that reactor. In such case, the anaerobic reactor should be used to treat initially only a part of the influent raw sewage (possibly no more than 50-70\%), and the remaining part (30-50\%) should be directed to the complementary biological treatment. The use of this "by-pass" will increase the COD of the reactor effluent making it more adequate to the next denitrification stage ${ }^{[20,21]}$.

Among the available technologies, biofiltration has been widely deployed in urban wastewater treatment plants. Biofiltration technology combines both physical and biological treatment by using an immersed filter material. During biofiltration treatment, the wastewater is simply passed through a fixed bed of media, which acts both as a filter and as a support for the growth of nutrient consuming bacteria. The advantages of these immersed biological systems reside in their compactness (small footprint) and low residence time ${ }^{[22]}$.

This work is focused on the study of the integration of denitrification/nitrification process treating domestic wastewater after anaerobic treatment. The specific aim of the study was the influence evaluation of the $\mathrm{COD} / \mathrm{N}$ ratio and the nitrate recycling ratio in nitrogen removal. To do so, a denitrification/nitrification pilot plant was designed, built and operated at different conditions. 


\section{MATERIALS AND METHODS}

\subsection{Experimental Setup}

The pilot plant consists of two fixed bed bioreactors able to develop the denitrification and nitrification in wastewater. Both reactors were designed as vertical cylinders. The height and diameter of the anoxic cylinder used for denitrification was $2.78 \mathrm{~m}$ and $0.15 \mathrm{~m}$, respectively, with a working volume of $20 \mathrm{~L}$. The height and diameter of the nitrification cylinder was $1.86 \mathrm{~m}$ and $0.30 \mathrm{~m}$, respectively, with $40 \mathrm{~L}$ of working volume. The anoxic bioreactor was filled with corrugated PVC rings, while the aerobic one with Filtralite as filter medium. A diagram of the pilot plant is shown in Figure 1. Temperature in the plant was maintained at $18 \stackrel{\circ}{ } \mathrm{C}$, which is the working temperature of the previous anaerobic reactor ${ }^{[2]}$. The denitrifying biofilter was equipped with measurement systems for pressure, gas flow and oxidation-reduction potential (ORP), while the nitrifying biofilter with a probe to measure the dissolved oxygen and temperature. The incoming flow was set to $20 \mathrm{~L} / \mathrm{h}$. The denitrification reactor was operated with a HRT of $2 \mathrm{~h}$ while the nitrification one at $4 \mathrm{~h}$. These HRT were previously optimized by studying each reactor individually. The aeration rate was controlled through a flow meter, maintaining the dissolved oxygen (DO) concentration between 2.0-2.5 $\mathrm{mg} \mathrm{O}_{2} / \mathrm{L}$. Four aerators were fixed on the bottom to make the bubbles distributed uniformly.

The plant was fed with the reject water of an anaerobic membrane bioreactor (AnMBR) that treated domestic wastewater under psychrophilic conditions $(18 \stackrel{\circ}{\circ})^{[2]}$. The wastewater with high concentration of $\mathrm{NH}_{4}{ }^{+}$and low level of organic matter was pumped to the anoxic reactor. In this first step, $\mathrm{NH}_{4}{ }^{+}$did not changed and passed through the aerobic reactor. In the second step, the $\mathrm{NH}_{4}{ }^{+}$was oxidized to $\mathrm{NO}_{3}{ }^{-}$in the presence of oxygen. This stream is recycled using a peristaltic pump, from the aerobic bioreactor to be the feed to the anoxic reactor, where the denitrifying bacteria can use the COD from the feedstream.

Due to the high DO concentration in the recycling water from the aerobic bioreactor, the organic carbon available in the feed water from anaerobic treatment would tend to be oxidized instead of being used for denitrification. As consequence, denitrification efficiencies would fall. To avoid this effect as far as possible, a degassing tank was placed in the recycling line to prevent dissolved oxygen entering into the anoxic tank. 


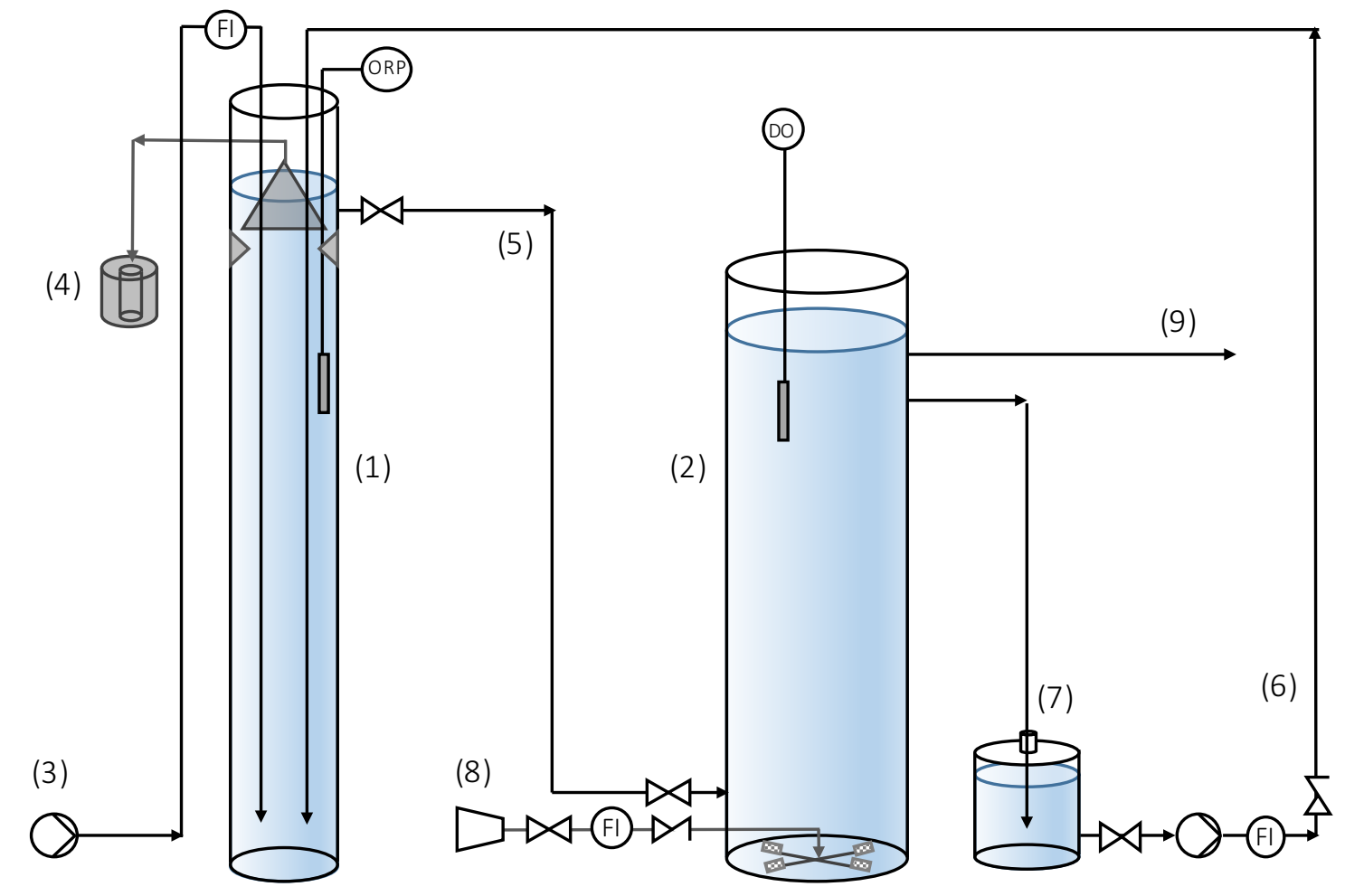

Figure 1: Pilot plant flow scheme. (1) Denitrification reactor, (2) nitrification reactor, (3) filling pump, supplies the wastewater from anaerobic treatment to the denitrifying reactor, (4) gas flow meter, (5) effluent from anoxic to aerobic reactor, (6) nitrate recycling from aerobic to anoxic reactor, (7) degassing tank, (8) compressor, responsible for supplying the air, (9) final effluent. ORP: oxidation-reduction potential probe; DO: dissolved oxygen; FI: flow-rate indicator; PI: pressure indicator.

\subsection{Inoculum and feed wastewater}

The inoculum of the denitrifying bioreactor was a mix of anoxic sludge and anaerobic digested sludge, taken from the wastewater treatment plant (WWTP) of Valladolid (Spain). The inoculum of the nitrifying bioreactor was secondary aerobic sludge from the same WWTP.

The studied plant was fed with the effluent from an AnMBR ${ }^{[2]}$ fed with raw municipal wastewater from the city of Valladolid (Spain). The average concentration of the main parameters of wastewater after anaerobic treatment are given in Table 1. It can be seen that the concentration of $\mathrm{NH}_{4}{ }^{+}-\mathrm{N}$ dominated the $\mathrm{TN}$, which leads to a $\mathrm{COD} / \mathrm{N}$ ratio as low as 1.04 . When the AnMBR effluent was sampled, the sulfide contained in the wastewater was oxidized to sulfate, and by chromatographic techniques this compound could be determined. In the inlet stream (from anaerobic treatment), sulfur is the corresponding amount of sulfide oxidation without quantify the oversaturation, so the real value for sulfide was expected to be higher than showed. 
Table 1: Feed composition of the studied process. (Mean \pm standard deviation of the mean. $<$ QL: Lower than quantification limit).

\begin{tabular}{ccccccc}
$\begin{array}{c}\mathrm{sCOD} \\
\left(\mathrm{mg} \mathrm{O}_{2} / \mathrm{L}\right)\end{array}$ & $\begin{array}{c}\mathrm{TKN} \\
(\mathrm{mg} \mathrm{N} / \mathrm{L})\end{array}$ & $\begin{array}{c}\mathrm{NH}_{4}{ }^{+} \\
(\mathrm{mg} \mathrm{N} / \mathrm{L})\end{array}$ & $\begin{array}{c}\mathrm{NO}_{2}{ }^{-} \\
(\mathrm{mg} \mathrm{N} / \mathrm{L})\end{array}$ & $\begin{array}{c}\mathrm{NO}_{3}{ }^{-} \\
(\mathrm{mg} \mathrm{N} / \mathrm{L})\end{array}$ & $\begin{array}{c}\mathrm{SO}_{4}{ }^{2-} \\
(\mathrm{mg} \mathrm{S} / \mathrm{L})\end{array}$ & $\begin{array}{c}\text { sol P } \\
(\mathrm{mg} \mathrm{P} / \mathrm{L})\end{array}$ \\
\hline $122.4 \pm 3.4$ & $118.0 \pm 3.5$ & $109.3 \pm 3.3$ & $<\mathrm{QL}$ & $<\mathrm{QL}$ & $8.7 \pm 0.2$ & $10.7 \pm 0.3$
\end{tabular}

\subsection{Analytical Methods}

Samples of wastewater were collected periodically before and after the denitrification reactor, and after the aerobic reactor, being this stream the effluent of the process. The concentration of nitrite, nitrate, sulfate and soluble phosphorus were measured by High Performance Liquid Chromatography (HPLC). Ammonium concentration was determined using an ammonia-selective electrode: Orion, model 9512HPBNWP. The analyses of Chemical Oxygen Demand (COD), Total Kjeldahl Nitrogen (TKN) as well as total and volatile suspended solids (TSS, VSS) were determined according to the Standard methods for examination of water and wastewater suggested by the manual APHA-AWWA-WPCF ${ }^{[23]}$. The measurement of dissolved oxygen concentration was determined with an oximeter WTW, model oxi 330/SET and a dissolved oxygen probe CeliOx 325. Gas production from the anoxic bioreactor was measured volumetrically by water displacement. Gas samples were taken from the headspace of this reactor and its composition in terms of methane, carbon dioxide, nitrogen, oxygen, hydrogen sulfide and hydrogen was determined by gas chromatography (GC) (Varian CP-3800). Pressure, temperature and oxidation reduction potential (ORP) were measured by using sensors and probes.

\subsection{Operation Strategy}

The denitrification/nitrification experiments were run for more than five consecutive months. Eight different scenarios were studied until reach the optimum $\mathrm{C} / \mathrm{N}$ ratio and nitrate recycling ratio (R). Each case was analyzed for around 20 days at steady state. Table 2 depicts the recycling ratio of nitrate $(R)$, the $C O D$, if there was (or not) addition of external carbon source and the $\mathrm{C} / \mathrm{N}$ ratio established for each case studied. 
Table 2: Characteristics of the cases implied in the operation strategy.

\begin{tabular}{ccccc} 
Case & $\mathrm{R}$ & Methanol & Soluble COD $\left(\mathrm{mg} \mathrm{O}_{2} / \mathrm{L}\right)$ & $\mathrm{C} / \mathrm{N}$ ratio \\
\hline 1 & $\mathrm{Q}$ & No & $106.0 \pm 2.1$ & 1.09 \\
2 & $2 \mathrm{Q}$ & No & $105.7 \pm 1.0$ & 1.12 \\
3 & $2 \mathrm{Q}$ & Yes & $286.5 \pm 3.6$ & 2.59 \\
4 & $3 \mathrm{Q}$ & Yes & $454.2 \pm 4.3$ & 3.74 \\
5 & $4 \mathrm{Q}$ & Yes & $448.7 \pm 1.5$ & 3.94 \\
6 & $5 \mathrm{Q}$ & Yes & $476.2 \pm 5.4$ & 4.87 \\
7 & $6 \mathrm{Q}$ & Yes & $574.0 \pm 3.2$ & 5.37 \\
8 & $6 \mathrm{Q}$ & Yes & $848.2 \pm 1.7$ & 8.25
\end{tabular}

In the cases 1 and 2, R was modified. The same parameter was changed in cases 4, 5 and 6 but with other $\mathrm{C} / \mathrm{N}$ ratio compared with cases 1 and 2 . All these cases are analyzed in section 3.1.

In cases 2 and $3, R$ was maintained but the $C / N$ ratio was increased by the addition of methanol. A different $\mathrm{R}$ was kept in cases 7 and 8 , but with higher $\mathrm{C} / \mathrm{N}$ ratio than comparing to the cases 2 and 3. These cases are discussed in section 3.2.

\section{RESULTS AND DISCUSSION}

\subsection{The effect of the recycling ratio of nitrate.}

The removal efficiency of organic matter and nitrogen in the denitrification-nitrification system changing the nitrate recycling ratio was studied. COD concentration in the influent was maintained constant and the recycling $R$ from the aerobic bioreactor effluent to the anoxic one was increased to study its effect. An increase in the recycling rate from the aerobic to the anoxic column, provides more nitrates to the denitrification reactor and thus, can improve the overall nitrogen removal and minimize the TN concentration in the effluent.

On the one hand, during the first part of the work, case 1 and 2 were experimented analyzing the recycling effect from $R=Q(Q$ : incoming flow) to $R=2 Q$, being the $C O D / N$ ratio of 1.09 and 1.12 for each condition.

Tables 3 and 4 , summarize the concentration average of the COD and the nitrogen compounds at different nitrate recycling ratios. $\mathrm{NH}_{4}{ }^{+}$concentration decreased significantly in the anoxic reactor due to the dilution of nitrate recycling stream. The average ammonium 
removal efficiency of the overall process was $86.1 \%$ in the case 1 , and $73.6 \%$ for the case 2 (Table 4). The removal profile of $\mathrm{NH}_{4}{ }^{+}-\mathrm{N}$ was analogous to that of COD, indicating that the utilization of organic matter and the degradation of $\mathrm{NH}_{4}{ }^{+}$occurred simultaneously. In Figure 2 it is shown the percentage of COD and TN removed. With the same COD influent of $106 \mathrm{mg} \mathrm{O}_{2} / \mathrm{L}$, the average COD removal efficiency was $87.6 \%$ and $74.4 \%$ for each situation, indicating a good ability to remove the organic matter. Contrary, the total nitrogen removal efficiency was poor with value of about $20 \%$. The $\mathrm{C} / \mathrm{N}$ ratio in the system was very low, being a limiting factor in the denitrification process, which was not able to remove the nitrogen compounds. $\mathrm{NO}_{3}{ }^{-}$was the prominent compound of TN in the effluent and this residual nitrogen was mainly due to the exhaustion of the carbon source of heterotrophs.

Table 3: COD concentration in the inlet, after the denitrification reactor and at the end of the process for the different conditions evaluated. (1: Wastewater influent; 2: Stream from the denitrification reactor to nitrification; 3: Nitrification effluent and the outlet of the plant). (Mean \pm standard deviation of the mean).

\section{soluble $\operatorname{COD}\left(\mathrm{mg} \mathrm{O}_{2} / \mathrm{L}\right)$}

\begin{tabular}{cccc} 
Case & 1 & 2 & 3 \\
\hline 1 & $106.0 \pm 2.1$ & $44.4 \pm 1.6$ & $13.1 \pm 1.3$ \\
2 & $105.7 \pm 1.0$ & $68.5 \pm 0.4$ & $27.1 \pm 0.2$ \\
3 & $286.5 \pm 3.6$ & $76.5 \pm 0.7$ & $22.3 \pm 0.9$ \\
4 & $454.2 \pm 4.3$ & $81.9 \pm 2.4$ & $31.9 \pm 2.8$ \\
\hline 5 & $448.7 \pm 1.5$ & $72.5 \pm 2.6$ & $20.0 \pm 3.7$ \\
\hline 6 & $476.2 \pm 5.4$ & $66.7 \pm 2.1$ & $27.7 \pm 3.3$ \\
7 & $574.0 \pm 3.2$ & $68.2 \pm 1.0$ & $21.5 \pm 0.6$ \\
8 & $848.2 \pm 1.7$ & $107.0 \pm 0.6$ & $33.8 \pm 0.2$
\end{tabular}


Table 4: Evolution of nitrogen compounds during the denitrification/nitrification process. (1: wastewater influent from AnMBR; 2: Stream from the denitrification reactor to nitrification; 3: Nitrification effluent and the outlet of the plant). (Mean \pm standard deviation of the mean. < QL: Lower than quantification limit).

\begin{tabular}{|c|c|c|c|c|c|c|c|c|c|c|c|c|}
\hline \multirow[b]{2}{*}{ Case } & \multicolumn{3}{|c|}{ TKN (mg N/L) } & \multicolumn{3}{|c|}{$\mathrm{NH}_{4}^{+}(\mathrm{mg} \mathrm{N} / \mathrm{L})$} & \multicolumn{3}{|c|}{$\mathrm{NO}_{2}^{-}(\mathrm{mg} \mathrm{N} / \mathrm{L})$} & \multicolumn{3}{|c|}{$\mathrm{NO}_{3}^{-}(\mathrm{mg} \mathrm{N} / \mathrm{L})$} \\
\hline & 1 & 2 & 3 & 1 & 2 & 3 & 1 & 2 & 3 & 1 & 2 & 3 \\
\hline 1 & $96.9 \pm 1.0$ & $33.6 \pm 0.6$ & $13.4 \pm 0.3$ & $93.0 \pm 1.0$ & $32.3 \pm 0.6$ & $12.9 \pm 0.3$ & $<Q L$ & $<Q L$ & $<Q L$ & $<Q L$ & $32.5 \pm 0.3$ & $61.2 \pm 0.6$ \\
\hline 2 & $94.2 \pm 1.0$ & $68.1 \pm 0.4$ & $28.4 \pm 0.2$ & $94.0 \pm 1.9$ & $57.6 \pm 1.2$ & $24.8 \pm 0.5$ & $<Q L$ & $<Q L$ & $<Q L$ & $<Q L$ & $28.6 \pm 0.6$ & $49.3 \pm 1.0$ \\
\hline 3 & $110.5 \pm 3.6$ & $52.8 \pm 0.7$ & $20.6 \pm 0.9$ & $107.3 \pm 0.6$ & $48.7 \pm 1.2$ & $17.8 \pm 0.4$ & $<Q L$ & $2.3 \pm 0.1$ & $<Q L$ & $<Q L$ & $24.8 \pm 0.3$ & $48.8 \pm 0.2$ \\
\hline 4 & $121.4 \pm 1.4$ & $42.9 \pm 1.5$ & $17.9 \pm 1.0$ & $119.0 \pm 1.3$ & $38.1 \pm 1.3$ & $15.2 \pm 0.9$ & $<Q L$ & $1.1 \pm 0.1$ & $<Q L$ & $<Q L$ & $25.0 \pm 0.5$ & $34.0 \pm 0.8$ \\
\hline 5 & $114.0 \pm 0.5$ & $49.8 \pm 0.4$ & $22.5 \pm 0.3$ & $111.0 \pm 0.5$ & $44.9 \pm 0.5$ & $20.8 \pm 0.4$ & $<Q L$ & $0.6 \pm 0.1$ & $<Q L$ & $<Q L$ & $10.2 \pm 1.1$ & $23.2 \pm 1.3$ \\
\hline 6 & $97.7 \pm 1.0$ & $37.7 \pm 0.7$ & $8.6 \pm 0.8$ & $85.8 \pm 1.5$ & $21.0 \pm 1.4$ & $5.4 \pm 0.9$ & $<Q \mathrm{~L}$ & $0.6 \pm 0.1$ & $<Q \mathrm{~L}$ & $<Q L$ & $32.8 \pm 1.0$ & $33.8 \pm 1.5$ \\
\hline 7 & $106.9 \pm 0.4$ & $18.1 \pm 0.9$ & $<Q L$ & $102.5 \pm 0.1$ & $12.0 \pm 0.4$ & $<Q L$ & $<Q \mathrm{~L}$ & $<Q L$ & $<Q L$ & $<Q L$ & $28.9 \pm 0.2$ & $32.5 \pm 0.1$ \\
\hline 8 & $102.8 \pm 1.7$ & $33.5 \pm 0.6$ & $7.2 \pm 0.2$ & $98.9 \pm 0.3$ & $29.8 \pm 0.2$ & $5.7 \pm 0.5$ & $<Q L$ & $<Q L$ & $<Q L$ & $<Q L$ & $3.9 \pm 0.05$ & $6.1 \pm 0.04$ \\
\hline
\end{tabular}


On the other hand, cases 4, 5 and 6 were analyzed pumping methanol to the system. It is interesting to note the cases 4,5 and 6 , where the COD concentration in the feed was approximately constant $\left(460 \mathrm{mg} \mathrm{O}_{2} / \mathrm{L}\right.$ ). In these situations, the $\mathrm{C} / \mathrm{N}$ ratio was adjusted around 4.1 by the addition of methanol. This adjustment was done to increase the available organic matter in the feed for the denitrification process. In those cases, the nitrate recycling ratio was changed as follows: $R=3 Q, 4 Q$ and $5 Q$. For this reason, the results showed a higher percentage of TN removal than the cases 1 and 2, with a TN removal of 57.3\%, 59.7\% and $56.2 \%$ for the cases 4,5 and 6, respectively, as can be seen in Figure 2.

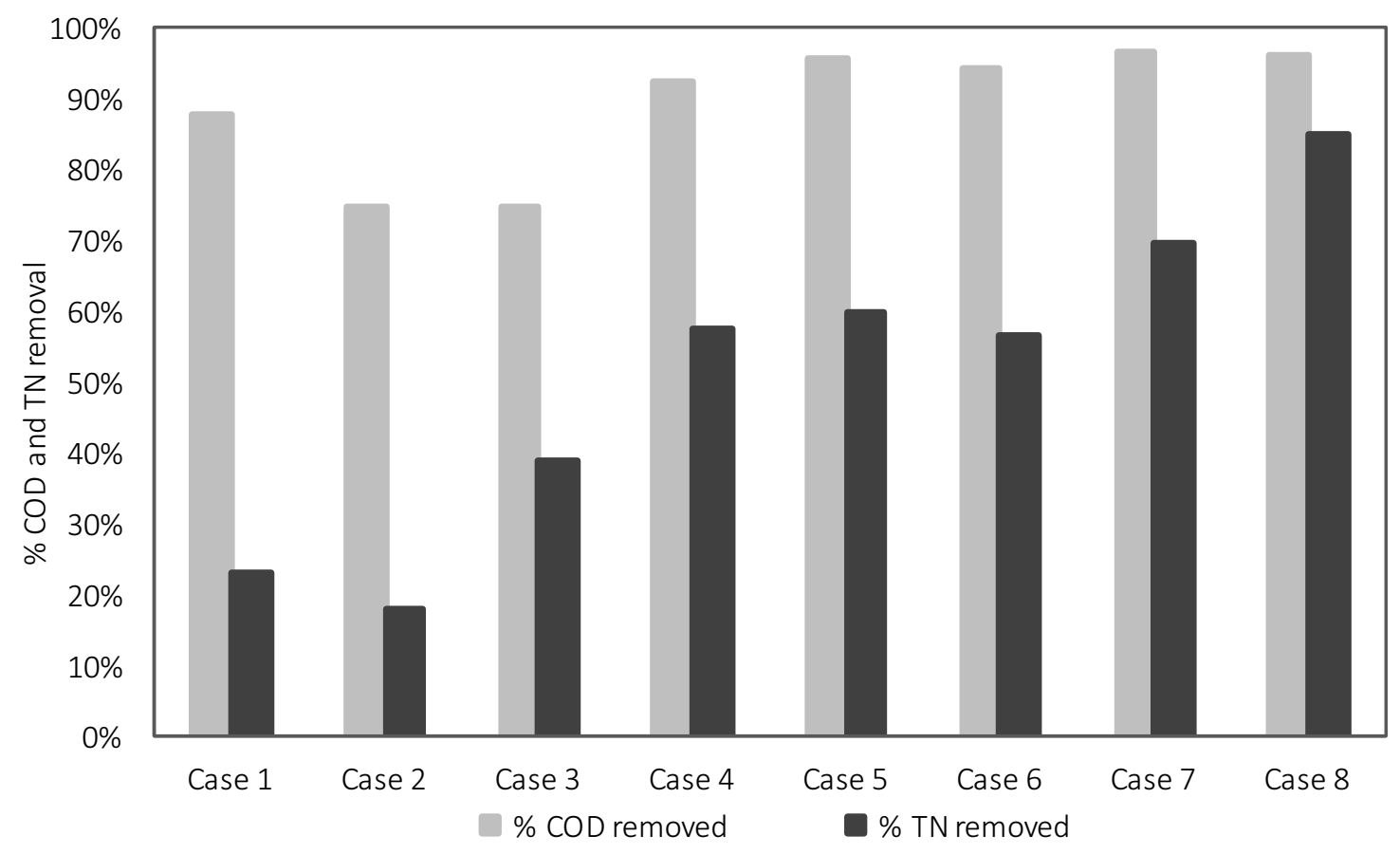

Figure 2: COD and TN removal percentages after the denitrification/nitrification process.

Contrary to expectations with respect TN and COD, there was no appreciable improvement in the removal efficiencies with an increase in the nitrate recycling rate for cases 4, 5 and 6 (Figure 2). In the cases compared in this part of the study, the same amount of organic matter for denitrifying was available. By increasing the recycling ratio of nitrate, the nitrate load supplied to the anoxic reactor was increased. There were more electron acceptors for the same amount of electron donors. Therefore, increasing $\mathrm{R}$ in the system, did not provoke an enhancement in the yield of the process, because of the lack of organic matter in the feed. For the wastewater studied, with a low $\mathrm{C} / \mathrm{N}$, a higher nitrate recycling ratio was not beneficial for nitrogen removal and it could be economically non-profitable. The enhancement in the TN removal efficiencies among cases 4,5 and 6 versus cases $1-2$, was due to the addition of methanol, which provided organic material to be used by denitrifying bacteria. The results 
obtained are in agreement with the results reported by Fongsatitkul et al. ${ }^{[24]}$, showing no improvement on the COD removal with respect the influence of R. On the other side, this author observed a modest improvement of $4-5 \%$ TKN removal when R doubled from $Q$ to $2 Q$, but no further increase at a recycling ratio of $4 Q$. In the case of Chen et al. ${ }^{[25]}$, at low COD/N ratio of 3.0, the $\mathrm{N}$ removal efficiency decreased when $\mathrm{R}$ increased, due to the limited carbon sources in anoxic zones, and only at high COD/N ratio of 5.5, the $\mathrm{N}$ removal efficiency steadily increased with $R$.

In Figure 3 is depicted the evolution of $\mathrm{TKN}$ and $\mathrm{NO}_{3}{ }^{-} \mathrm{N}$ concentration in the different situations studied in the work. In the left column is represented the feed and in the right one, the effluent after denitrification/nitrification process. It can be observed a clear decrease in the TKN effluent compared to the inlet concentration in all the analyzed cases, indicating a good nitrification yield. The case 2 , the most unfavorable case in terms of operating conditions, shows the worst yield of nitrification and a TN removal. The graphics of the cases 4,5 and 6 , show no considerable differences between them.

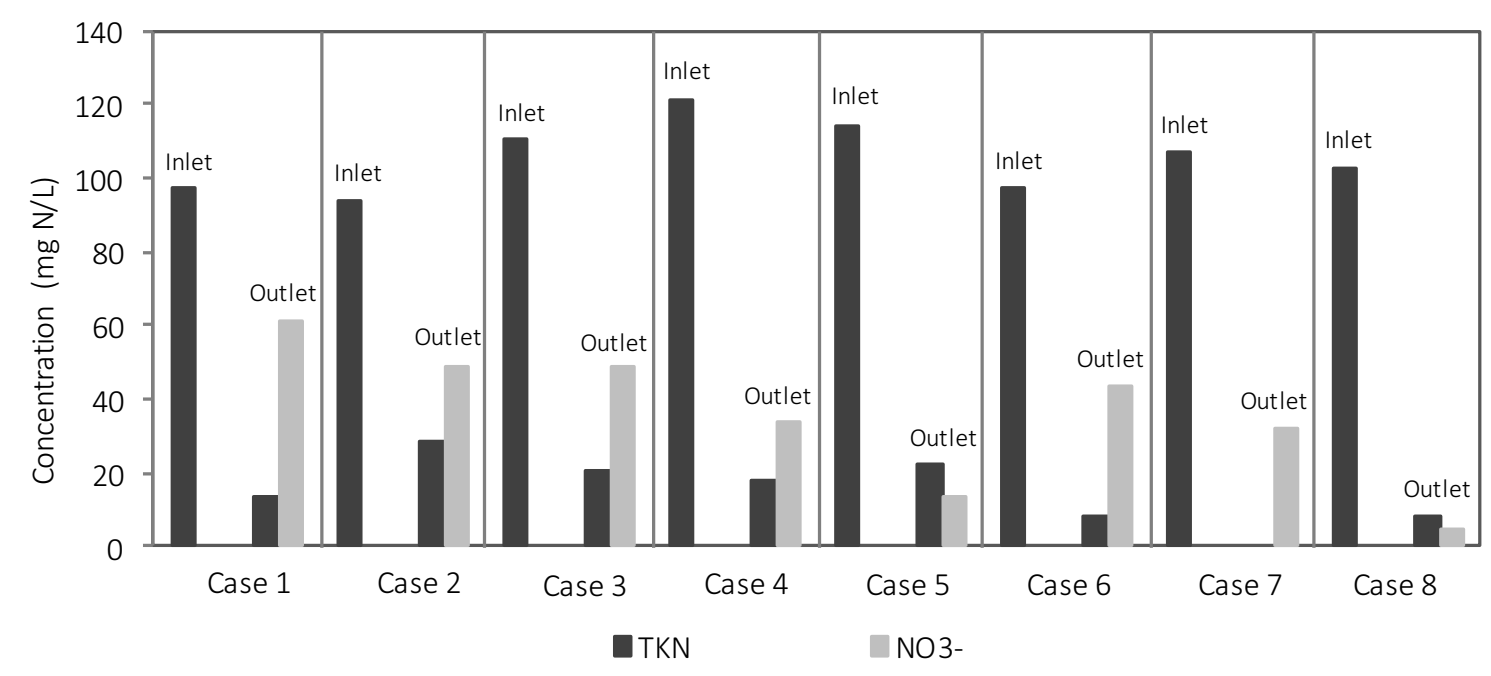

Figure 3: Comparison of nitrogen compound concentrations in the different cases, before and after denitrification/nitrification treatment.

Sometimes incomplete denitrification can produce $\mathrm{N}_{2} \mathrm{O}$, which is an intermediary product in denitrification processes. This can be problematic as $\mathrm{N}_{2} \mathrm{O}$ is a potent greenhouse gas and contributes to increasing the earth's temperature and destructing the ozone layer ${ }^{[26]}$. Gas samples taken from the bioreactor showed concentrations lower than $9 \mathrm{mg} / \mathrm{L}$ of $\mathrm{N}_{2} \mathrm{O}$ gas in its headspace, corresponding to less than $10 \%$ of the $\mathrm{N}$ removed. 


\subsection{The effect of increasing the $\mathrm{COD} / \mathrm{N}$ ratio.}

The removal efficiency of nutrient and organic carbon in the denitrification-nitrification system with different $\mathrm{COD} / \mathrm{N}$ ratios was also studied. In a wastewater treatment plant, part of the stream that feeds the anaerobic reactor is derived through a bypass, to the stream that feeds the denitrification reactor. With this course of action, it is possible to increase the soluble COD available in the liquid stream that feeds the denitrification reactor, and minimizing the adding of external carbon sources. In this work, methanol was employed as extra carbon source, in order to simulate the increment of the denitritation potential by increasing the concentration of organic matter available in the system.

The $\mathrm{C} / \mathrm{N}$ ratio of the wastewater after anaerobic treatment was around 1.1 (cases 1 and 2), showing a lack of carbon source to promote the denitrification process. On the one side, comparing the cases 2 and 3, methanol was added to enhance the denitrification step increasing the $\mathrm{C} / \mathrm{N}$ ratio from 1.1 to 2.6 , while nitrate recycling ratio was maintained at $200 \%$ $(R=2 Q)$. The corresponding removal efficiencies of TN were doubled from $17.6 \%$ to $38.7 \%$ as can be seen in Figure 2. With regard to organic matter, the removal efficiency of COD enhanced from $74.4 \%$ to $92.2 \%$, with a concentration effluent of $27.1 \mathrm{mg} \mathrm{O}_{2} / \mathrm{L}$ in the case 2 , and $22.3 \mathrm{mg}$ $\mathrm{O}_{2} / \mathrm{L}$ in the case 3 (Table 3). As depicted in Figure $3, \mathrm{NO}_{3}{ }^{-} \mathrm{N}$ in the effluent of the denitrification/nitrification process remained almost with the same concentration. Looking at TKN, the effluent concentration in the case 3 was around 25\% lower than case 2, despite the fact that in case 3 the feeding concentration was almost 15\% higher than in case 2 .

On the other side, looking at cases 7 and 8 , nitrate recycling ratio from the aerated bioreactor was maintained at $600 \%(R=6 Q)$ and methanol was added to increase the COD in the feeding. In the case 7 , the COD was $574.0 \mathrm{mg} \mathrm{O}_{2} / \mathrm{L}$ and the $\mathrm{C} / \mathrm{N}$ ratio was 5.37 , as indicated in Table 2. More amount of methanol was added in case 8 , where $848.2 \mathrm{mg} \mathrm{O}_{2} / \mathrm{L}$ was the inlet COD, changing the COD/TN ratio from 5.37 to 8.25 . In comparison to case 7 , with this raise in the concentration of COD in the feed, the nitrogen removal efficiency shown a substantial improvement from $69.6 \%$ to $84.7 \%$ (Figure 2), obtaining effluents with $32.5 \mathrm{mg} \mathrm{N} / \mathrm{L}$ and $13.3 \mathrm{mg}$ $\mathrm{N} / \mathrm{L}$ of total nitrogen in cases 7 and 8 , respectively (Table 4). The two situations got a high COD removal of around $96.1 \%$. Figure 3 shows the high decrease in the $\mathrm{NO}_{3}{ }^{-} \mathrm{N}$ concentration column after the denitrification/nitrification process.

Summarizing, the greater the influent $\mathrm{C} / \mathrm{N}$ was, the better the TN removal was obtained. Similar observation were done by Han et al. ${ }^{[27]}$, Wang et al. ${ }^{[28]}$ and Kumar et al. ${ }^{[12]}$. Therefore, 
based in the results, the denitrification capacity of the system was affected by the availability of COD present in the influent and the addition of COD was a very important point in the nitrogen removal.

Considering on the one hand, that the COD of the wastewater before the AnMBR reactor (after the sedimentation tank) is $610 \mathrm{mg} \mathrm{O}_{2} / \mathrm{L}^{[2]}$, and on the other hand, the by-pass of $50 \%$ of influent raw sewage, the requirements of methanol to achieve $848 \mathrm{mg} \mathrm{O}_{2} / \mathrm{L}$ would be diminished in $33.6 \%$.

Fu et al. found removal efficiencies of $96.2 \%$ for COD and $83 \%$ for TN, with rather longer HRT than the achieved in this work: 1.5 days versus 6 hours. The process they developed was a modified membrane bioreactor with two parts for the anoxic and aerobic compartments that treated synthetic wastewater with a $\mathrm{C} / \mathrm{N}$ ratio of $9.3^{[16]}$.

Azhdarpoor et al. ${ }^{[29]}$ obtained $92 \%$ and $86 \%$ of COD and TN removal, respectively with a SBR configuration but with a synthetic wastewater with a $\mathrm{C} / \mathrm{N}$ ratio much higher than the experimented in this work $(\mathrm{C} / \mathrm{N}=19$ versus $\mathrm{C} / \mathrm{N}=8.3)$ and 8 hours of TRH (versus $6 \mathrm{~h}$ in this study)

Among the cases studied in the work, in cases 7 and 8 took place the largest increases in the TN removal efficiency. More specifically, the removal efficiency of TN was increased by $40.7 \%$ between the cases 1 and 3; 35.1\% of TN removal efficiency increase was observed when comparing the cases 3 and 5; and 29.5\% was the increase in the TN removal efficiency between the cases 5 and 8.

There was no significant difference in the phosphorus concentration between the influent and effluent in any case. The wastewater would require one specific treatment for its elimination.

Thus the denitrification-nitrification system could achieve a long-term stability for removal of nitrogen with the addition of methanol, obtaining an effluent that likely complies with the legislative requirements for discharge into waters, as regards organic matter and nitrogen ${ }^{[3]}$.

The results obtained in this work showed a big improvement over the processes already developed by other authors and described in the literature. Similar values of COD and TN removal were achieved to those developed in literature but using shorter residence time and lower COD, which implies as consequence, the use of smaller equipment and a lower addition of chemicals. 
As future work it is proposed to evaluate the effect of increasing the carbon ratio on the nitrogen elimination potential using the mixing of the anaerobic reactor effluent and the raw feed.

\section{CONCLUSIONS}

The developed process is an interesting alternative to eliminate the nitrogen and organic matter present in the wastewater from an anaerobic reactor, with very low $\mathrm{C} / \mathrm{N}$ ratios. The proposed system was a denitrification/nitrification integrated process with a short HRT of $2 \mathrm{~h}$ for the anoxic bioreactor and $4 \mathrm{~h}$ for the aerobic one.

The successful results of the system to remove COD and TN from domestic wastewater after anaerobic treatment could be achieved mainly due to the addition of methanol. Methanol increased the molar ratio of $\mathrm{C} / \mathrm{N}$ in the wastewater accelerating the nitrification and denitrification rates, being the key point in the nitrogen removal. On the other hand, despite nitrate recycling did not suppose a significant improvement in the process, it improved the homogeneous distribution of microbial communities in the reactors increasing the removal efficiency of nitrogen.

The optimal nitrogen and organic matter removal were $84.7 \%$ and $96 \%$, respectively. The optimized process was performed under a nitrate recycling ratio of six times the feeding flow $(600 \%)$ and addition of methanol until obtaining an inlet $\mathrm{C} / \mathrm{N}$ ratio of 8.25 and a COD concentration of almost $850 \mathrm{mg} \mathrm{O}_{2} / \mathrm{L}$. As result of the combined impacts, it was obtained an effluent that met the requirements of wastewater discharge, in terms of organic matter and nitrogen content.

It is noteworthy that the enhancement of the C/D ratio can be made by bypassing part of the feedstream from a point before the anaerobic treatment to another point in the end of this reactor. In this way, it is provided to the denitrification process a feed with a higher concentration in organic matter, and therefore, the external carbon source need is reduced.

\section{ACKNOWLEDGEMENTS}

The authors thank the company Cadagua S.A., the European Regional Development Fund, the project IPT-2011-1078-310000, and the INNPACTO 2011 program of the Ministry of Economy and Competitiveness for the technical and financial support. 


\section{References}

1. Y. Yang, G. Lesage, M. Barret, N. Bernet, A. Grasmick, J. Hamelin and M. Heran, New urban wastewater treatment with autotrophic membrane bioreactor at low chemical oxygen demand/N substrate ratio, Water Science and Technology, 2014, 69(5), p.960965.

2. J. Gouveia, F. Plaza, G. Garralon, F. Fdz-Polanco and M. Peña, A novel configuration for an anaerobic submerged membrane bioreactor (AnSMBR). Long-term treatment of municipal wastewater under psychrophilic conditions, Bioresource Technology, 2015, 198510-519.

3. RD 509/1996, BOE 77, https://www.boe.es/boe/dias/1996/03/29/pdfs/A1203812041.pdf, (accessed 03/30/2016).

4. MAGRAMA, Manual para la gestión de vertidos, Ministerio de Agricultura, Alimentación y Medio Ambiente. Gobierno de España, 2007.

5. C. Cherchi, A. Onnis-Hayden, I. El-Shawabkeh and A. Z. Gu, Implication of Using Different Carbon Sources for Denitrification in Wastewater Treatments, Water Environment Research, 2009, 81(8), p.788-799.

6. M. Ruscalleda Beylier, M. D. Balaguer, J. Colprim, C. Pellicer-Nàcher, B. J. Ni, B. F. Smets, S. P. Sun and R. C. Wang, in Comprehensive Biotechnology (Second Edition), ed. M. MooYoung, Academic Press, Burlington, 2011, pp. 329-340.

7. Z. Hu, D. Houweling and P. Dold, Biological Nutrient Removal in Municipal Wastewater Treatment: New Directions in Sustainability, Journal of Environmental Engineering, 2012, 138307-317.

8. D. Xu, H. Chen, X. Li, Q. Yang, T. Zeng, K. Luo and G. Zeng, Enhanced biological nutrient removal in sequencing batch reactors operated as static/oxic/anoxic (SOA) process, Bioresource Technology, 2013, $143204-211$.

9. J. C. A. Marin, A. H. Caravelli and N. E. Zaritzky, Nitrification and aerobic denitrification in anoxic-aerobic sequencing batch reactor, Bioresource Technology, 2016, 200380 - 387.

10. M. Hatamoto, K. Ohtsuki, N. Maharjan, S. Ono, K. Dehama, K. Sakamoto, M. Takahashi and T. Yamaguchi, Performance evaluation of the sulfur-redox-reaction-activated upflow anaerobic sludge blanket and down-flow hanging sponge anaerobic/anoxic sequencing batch reactor system for municipal sewage treatment, Bioresource Technology, 2016, 204171 - 176. 
11. G. Tallec, J. Garnier and M. Gousailles, Nitrogen removal in a wastewater treatment plant through biofilters: nitrous oxide emissions during nitrification and denitrification, Bioprocess and Biosystems Engineering, 2006, 29(5), p.323-333.

12. M. Kumar, P.-Y. Lee, T. Fukusihma, L.-M. Whang and J.-G. Lin, Effect of supplementary carbon addition in the treatment of low C/N high-technology industrial wastewater by $\{M B R\}$, Bioresource Technology, 2012, 113148 - 153.

13. M. Waki, H. Yokoyama, A. Ogino, K. Suzuki and Y. Tanaka, Nitrogen removal from purified swine wastewater using biogas by semi-partitioned reactor, Bioresource Technology, 2008, 99(13), p.5335-5340.

14. L. Deng, H. Chen, Z. Chen, Y. Liu, X. Pu and L. Song, Process of simultaneous hydrogen sulfide removal from biogas and nitrogen removal from swine wastewater, Bioresource Technology, 2009, 100(23), p.5600-5608.

15. S. Kim, W. Bae, M. Kim, J.-O. Kim and J. Chung, Evaluation of denitrification-nitrification biofilter systems in treating wastewater with low carbon: nitrogen ratios, Environmental Technology, 2015, 36(8), p.1035-1043.

16. Z. Fu, F. Yang, F. Zhou and Y. Xue, Control of COD/N ratio for nutrient removal in a modified membrane bioreactor (MBR) treating high strength wastewater, Bioresource Technology, 2009, 100(1), p.136 - 141.

17. C. E. D. Santos, R. B. Moura, M. H. R. Z. Damianovic and E. Foresti, Influence of COD/N ratio and carbon source on nitrogen removal in a structured-bed reactor subjected to recirculation and intermittent aeration (SBRRIA), Journal of Environmental Management, 2016, 166519 - 524.

18. Y. Shi, G. Wu, N. Wei and H. Hu, Denitrification and biofilm growth in a pilot-scale biofilter packed with suspended carriers for biological nitrogen removal from secondary effluent, Journal of Environmental Sciences, 2015, 3235 - 41.

19. B. Jung, I. Jung and N. Sung, Development of alternative external carbon source for advanced sewage treatment system and its field applicability assessment, KSCE Journal of Civil Engineering, 2010, 14(2), p.149-154.

20. C. A. L. Chernicharo, Post-treatment options for the anaerobic treatment of domestic wastewater, Reviews in Environmental Science and Biotechnology, 2006, 5(1), p.73-92.

21. C. A. L. Chernicharo, J. B. van Lier, A. Noyola and T. Bressani Ribeiro, Anaerobic sewage treatment: state of the art, constraints and challenges, Reviews in Environmental Science and Bio/Technology, 2015, 14(4), p.649-679.

22. V. Rocher, A. M. Laverman, J. Gasperi, S. Azimi, S. Guérin, S. Mottelet, T. Villières and A. Pauss, Nitrite accumulation during denitrification depends on the carbon quality and 
quantity in wastewater treatment with biofilters, Environmental Science and Pollution Research, 2015, 22(13), p.10179-10188.

23. Apha, Standard Methods for the Examination of Water and Wastewater, American Public Health Association, Washington D.C., USA, 1998.

24. P. Fongsatitkul, D. G. Wareham, P. Elefsiniotis and P. Charoensuk, Treatment of a slaughterhouse wastewater: effect of internal recycle rate on chemical oxygen demand, total Kjeldahl nitrogen and total phosphorus removal, Environmental Technology, 2011, 32(15), p.1755-1759.

25. Y. Chen, B. Li, L. Ye and Y. Peng, The combined effects of COD/N ratio and nitrate recycling ratio on nitrogen and phosphorus removal in anaerobic/anoxic/aerobic (A2/O)biological aerated filter (BAF) systems, Biochemical Engineering Journal, 2015, 93235 242.

26. M. Liu, Q. Yang, Y. Peng, T. Liu, H. Xiao and S. Wang, Treatment performance and N2O emission in the UASB-A/O shortcut biological nitrogen removal system for landfill leachate at different salinity, Journal of Industrial and Engineering Chemistry, 2015, $3263-71$.

27. X. Han, Z. Wang, J. Ma, C. Zhu, Y. Li and Z. Wu, Membrane bioreactors fed with different COD/N ratio wastewater: impacts on microbial community, microbial products, and membrane fouling, Environmental Science and Pollution Research, 2015, 22(15), p.11436-11445.

28. Y. Wang, Y. Peng and T. Stephenson, Effect of influent nutrient ratios and hydraulic retention time (HRT) on simultaneous phosphorus and nitrogen removal in a two-sludge sequencing batch reactor process, Bioresource Technology, 2009, 100(14), p.3506 3512 .

29. A. Azhdarpoor, P. Mohammadi and M. Dehghani, Simultaneous removal of nutrients in a novel anaerobic-anoxic/aerobic sequencing reactor: removal of nutrients in a novel reactor, International Journal of Environmental Science and Technology, 2015, 13(2), p.543-550. 


\title{
Chapter 6. Techno-economical study of a domestic wastewater treatment system.
}

\begin{abstract}
The techno-economical feasibility of the membrane anaerobic treatment of wastewater eliminating nitrogen has been simulated. The process was simulated using experimental data analyzing the influence of different electron donors (methane, organic matter and sulfide) on the nitrogen elimination capacity. Different scenarios have been assessed changing the concentration of the involved components and evaluating their effect on the nitrogen elimination capacity as well as the ability to produce biogas in the anaerobic treatment. These scenarios imply on the one hand, the increment of the available soluble COD for the nitrogen elimination stage. The COD feed to the reactor was adjusted at values between $15 \%$ and $30 \%$ assuming different mixing ratios with the influent stream of the anaerobic reactor. On the other hand, different flows of biogas from the anaerobic reactor were pumped to the denitritation reactor. The goal was to achieve a nitrogen elimination capacity to reach an effluent with $10-20 \mathrm{mg} \mathrm{N} / \mathrm{L}$. Then, the most promising scenario was studied in detail and it was compared to the costs associated to the WWTP with a biological anaerobic treatment using a MBR system. The results indicated that the proposed process is feasible since the fixed and variables costs of both treatment plants are similar.
\end{abstract}

Keywords: COD • Biogas $\bullet$ 


\section{INTRODUCTION}

Besides the removal of COD, nutrient removal, especially the removal of nitrogen $(\mathrm{N})$, is also of increasing concern during the wastewater treatment process ${ }^{[1]}$. Nitrification-denitrification, which is the most common biological nitrogen removal (BNR) method in conventional wastewater treatment plants (WWTP), is an energy intensive process that couples chemical oxygen demand (COD) and nitrogenous oxygen demand (NOD) removal. High NOD increases the need for oxygen supply and aeration, which is the dominant the energy consuming process $(\sim 50 \%)$ in typical WWTPs with $\mathrm{N}$ removal ${ }^{[1,2]}$.

In the absence of a suitable electron acceptor, a consortia of microorganisms convert organic matter to methane $\left(\mathrm{CH}_{4}\right)$ and carbon dioxide $\left(\mathrm{CO}_{2}\right)$, which can be used as biogas for either heat or electricity generation. Several life cycle assessments have confirmed that anaerobic digestion is a sustainable waste-to-energy system from the prospects of both energy production and greenhouse gas $(\mathrm{GHG})$ emissions ${ }^{[3,4]}$. Compared to other techniques for energy recovery, anaerobic digestion is a mature method that is already widely used in WWTPs for recovering energy in the form of methane-rich biogas produced during digestion of primary sludge and biomass generated during conventional aerobic treatment ${ }^{[1]}$. Generally considered as an unfavorable byproduct of wastewater treatment, waste biomass from activated sludge processes can also be thought as a raw material for energy production ${ }^{[1,5]}$. Advanced wastewater treatment plants are now making significant progress towards energy neutrality through installation of, among others, anaerobic digestion and nitritation-denitritation processes.

One of the useful outcomes of a process simulation is that different working scenarios can be evaluated. The results of these simulations can be used to create a holistic view of the system. In addition, it is possible to determine the response of the system when the process parameters are varied. This is one of the most convenient ways to perform an economical feasibility assessment of a process.

The model employed in the simulation performed in this research work is able to determine the overall nitrogen elimination capacity of a nitritation-denitritation system depending on the quality of the influent under different working scenarios. This result would point the right design of the process as well as the effluent characteristics.

Aiming to employ realistic values for the study, the operation parameters used in the simulation were gotten from previous experimentations. 
The objective of this work was to evaluate the economical feasibility of the nitrogen elimination technology developed in this thesis. In addition, the work was focused in finding the sensitive parameter that can be modified to get the biggest conversion of nitrite to nitrogen gas in the denitritation process.

\section{MATERIALS AND METHODS.}

The composition of the influent water to the system is shown in Table 1.

Table 1: Composition of the influent water.

\begin{tabular}{lc} 
Parameter & Concentration \\
\hline Total COD $\left(\mathrm{mg} \mathrm{O}_{2} / \mathrm{L}\right)$ & 771 \\
\hline Soluble COD $\left(\mathrm{mg} \mathrm{O}_{2} / \mathrm{L}\right)$ & 491 \\
$\mathrm{TSS}(\mathrm{g} / \mathrm{L})$ & 0.14 \\
$\mathrm{VSS}(\mathrm{g} / \mathrm{L})$ & 0.12 \\
$\mathrm{NO}_{2}{ }^{-} \mathrm{-N}(\mathrm{mg} \mathrm{N} / \mathrm{L})$ & 1.52 \\
$\mathrm{NO}_{3}{ }^{-} \mathrm{N}(\mathrm{mg} \mathrm{N} / \mathrm{L})$ & 1.56 \\
$\mathrm{TKN}^{-\mathrm{mg} \mathrm{N} / \mathrm{L})}$ & 93.29 \\
$\mathrm{NH}_{4}{ }^{+}-\mathrm{N}(\mathrm{mg} \mathrm{N} / \mathrm{L})$ & 69.54 \\
$\mathrm{SO}_{4}{ }^{2-}-\mathrm{S}(\mathrm{mg} \mathrm{S} / \mathrm{L})$ & 16.88 \\
$\mathrm{PO}_{4}{ }^{3-}-\mathrm{S}(\mathrm{mg} \mathrm{P} / \mathrm{L})$ & 9.82
\end{tabular}

A schema of the simulated set up is depicted in Figure 1. The system is composed of: an anaerobic membrane bioreactor (AnMBR) ${ }^{[6]}$, a denitritation reactor and a nitritation reactor. $\mathrm{A}$ fraction of the nitritation reactor effluent is recycled to the denitritation reactor.

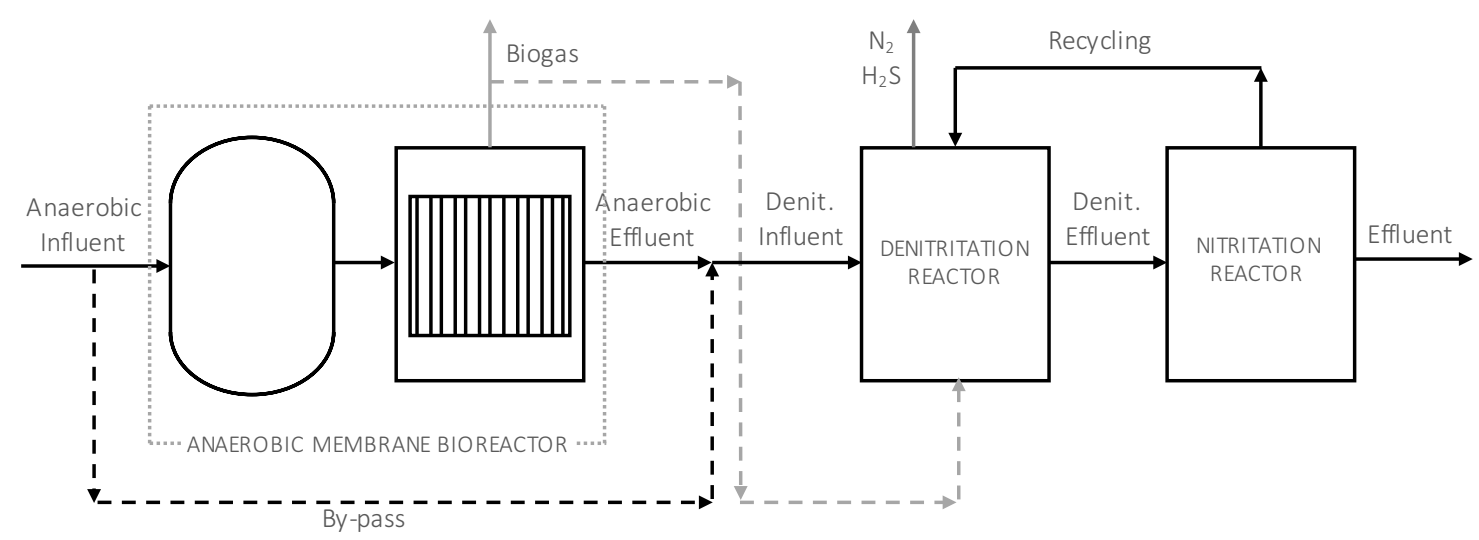

Figure 1: Scheme of the simulated setup. 
The denitritation stage is fed with the effluent from an anaerobic membrane reactor, so, the study of this reactor was also included in the model. A variation in the process flow diagram, like the addition of a by-pass to the first stage to increase the organic matter content of its effluent, could affect the quality of the effluent. Consequently, this change would also affect the simulation of the next operation in the process. It is also important to point that the simulation was performed considering stoichiometric reactions of the components involved in the process.

The ammonium in the wastewater is oxidized into nitrite in the nitritation process. Then, the nitrite is transformed to nitrogen in the denitritation reactor using different electron donors ${ }^{[7-9]}$. It was considered to carry out the denitritation with the residual organic matter, sulfide ${ }^{[10,11]}$ and methane ${ }^{[12,13]}$ present in the water since this process is performed after the anaerobic treatment. Different sulfide and methane sources were considered and their contributions were evaluated on the capacity of overall denitritation of the system. Sulfide and methane can be used as endogenous electron donors source for biological denitrification of wastewater.

The autotrophic denitrification employing sulfide and the heterotrophic denitrification employing methane could be insufficient to convert the entire amount of nitrite gotten in the initial process into nitrogen. In this case, it is necessary to add organic matter as source of electron donors. The main source of sulfide and methane is gotten from the liquid effluent from the anaerobic reactor ${ }^{[14,15]}$, where those components are dissolved and oversaturated ${ }^{[16]}$. This phenomenon takes place because the organic matter is transformed into biogas in the anaerobic process, which is composed of sulfide and methane among other gases. The sulfide concentration in the influent stream to the denitrification process can be determined by calculating the amount of sulfide produced during the anaerobic digestion by the sulfate reducing bacteria ${ }^{[17,18]}$. The sulfur mass balance determined that the sulfur concentration as sulfide in the biogas is not equivalent to the sulfate oxidation in the anaerobic process. So, this concentration should be referred to the sulfide occluded in the anaerobic process effluent. On the other hand, the heterotrophic denitritation is carried out using the methane occluded in the influent. The net methane production in the anaerobic process was estimated employing experimental data. This amount is lower than the theoretical amount of methane produced from the eliminated organic matter. This difference can be attributed to the methane which is occluded in the liquid influent, in the same way that it was analyzed for sulfide. The concentration of these available components to perform the denitrification will be determined by characterization of the influent water to the anaerobic process and its operation regarding the capacities of: organic matter elimination and sulfate to sulfide reduction. Considering the explained above, the denitrification capacity of the system will be determined by the 
concentration of sulfide, methane and organic matter in the influent. Nevertheless, this capacity can be modified by changing the concentration of organic matter in the influent water or adding the methane and sulfide produced as biogas in the anaerobic reactor as source of electron donors. This can be achieved by connecting the biogas produced in the anaerobic reactor to the denitrification reactor (see the dashed line in Fig 1). During the experimental stage, it was only possible to carry out the denitrification when synthetic nitrites were added to the feed (Chapter 3 and 4). It was not possible to get the partial nitritation in the nitrification reactor (Chapter 5). So, in this study, it is compared both processes: nitritation/denitritation and nitrification/denitrification.

The different scenarios were simulated to study its influence in the denitritation/denitrification process.

\subsection{Mass and energy balances:}

Mass and energy balances calculation were conducted in order to study the influence of the different effects. The main equations used in the study are the following:

\section{COD effect:}

Total COD available $=C O D_{\text {anaerobic effluent }}+C O D_{\text {bypass }}$

Total denit.potential $=\left(\mathrm{NO}_{x}^{-}-\mathrm{N}\right)_{\text {final effluent }}+\left(\mathrm{OM}+\mathrm{CH}_{4}+\mathrm{H}_{2} \mathrm{~S}\right)_{\text {denit.capacity }}+$ $\left(\mathrm{NO}_{x}^{-}-\mathrm{N}\right)_{\text {removed }}$ with the recycled anaerobic biogas

Electric energy produced $=$ Electric energy $y_{\text {from } \mathrm{CH}_{4}} \cdot \eta_{\text {electrical biogas }}$

Electric energy ${\text { from } \mathrm{CH}_{4}}=\mathrm{CH}_{4}$ production from biogas $\cdot \mathrm{GCV}_{\text {methane }} \cdot \eta$

Where $\eta_{\text {electrical biogas }}$ is the electrical efficiency of biogas. Electric energy is considered $1 / 3$ of the thermal energy, so this value is $0.33 ; G C V$ is the methane gross calorific value (9530 $\left.\mathrm{Kcal} / \mathrm{Nm}^{3}\right) ; \eta$ is a yield of $90 \%$ because it is considered $10 \%$ of energy loss.

\section{Effect of Recycling biogas:}

$\%$ Recycled Biogas $=\frac{Q \cdot\left(C_{\left.\text {outlet } \mathrm{NO}_{\bar{\chi}}^{-}\right) \cdot\left(\mathrm{CH}_{4} / \mathrm{NO}_{\chi}^{-}\right.} \text {stoichiometric ratio }\right)}{\left(\text { Biogas production }_{\text {from anaerobic reactor }}\right) \cdot\left(\% \mathrm{CH}_{4 \text { in biogas }}\right)}$

Where $Q$ is the feed flow of the simulated process $\left.\left(20000 \mathrm{~m}^{3} / \mathrm{d}\right)\right) ; C_{\text {outlet }} \mathrm{NO}_{\bar{x}}^{-}$is the $\mathrm{NO}_{\bar{x}}^{-} \mathrm{N}$ concentration after denitritation/denitrification process; $\mathrm{CH}_{4} / \mathrm{NO}_{x_{\text {estequiometric ratio }}}$ is the stoichiometric ratio from the reaction. 


\section{RESULTS AND DISCUSSION.}

\subsection{COD Effect}

One of the most effective methods to increase the denitrification capacity by increasing the organic matter concentration of the influent is achieved by mixing a fraction of the influent to the anaerobic reactor with the effluent of that reactor. The use of this "by-pass" will increase the COD of the reactor effluent making it more adequate to the next denitrification stage.

Different scenarios were evaluated. The volumetric flow bypassed to the anaerobic reactor are supposed to vary in $5 \%, 7 \%$ and $10 \%$ of the total feed to the anaerobic reactor. In this way, from Eq. 1 it is possible to increase the available soluble COD in 15\%, 21\% and 30\% respectively, in comparison to the initial, when there was not by-pass. So, from Eq.2 the denitritation potential can be increased in $4.5 \%, 6.3 \%$ and $9 \%$ respectively, depending on the bypassed flow. This behavior is depicted in Figure 2.

In the denitrification case (Figure 2), the denitrification potential change with available COD is small because the relationship acceptors/donors is higher. So, the effect of increasing the available organic matter on the denitrification potential in this case is slight, with values of $1.6 \%$, $2.2 \%$ and $3.2 \%$ (Eq.2).

The total capacity of denitritation/denitrification is calculated as the sum of the denitritation/denitrification capacities of organic matter, methane and sulfides available (Eq.2). The increment in the potential is obtained because of the increase of the organic matter. It has to be considered that in those cases, the concentration of sulfide and methane is reduced when the bypassed flow is increased. This is an expected behavior since the bypass implies the reduction of the treated flow in the anaerobic reactor and it will be translated in less soluble COD available for the production of biogas (methane and sulfide). 


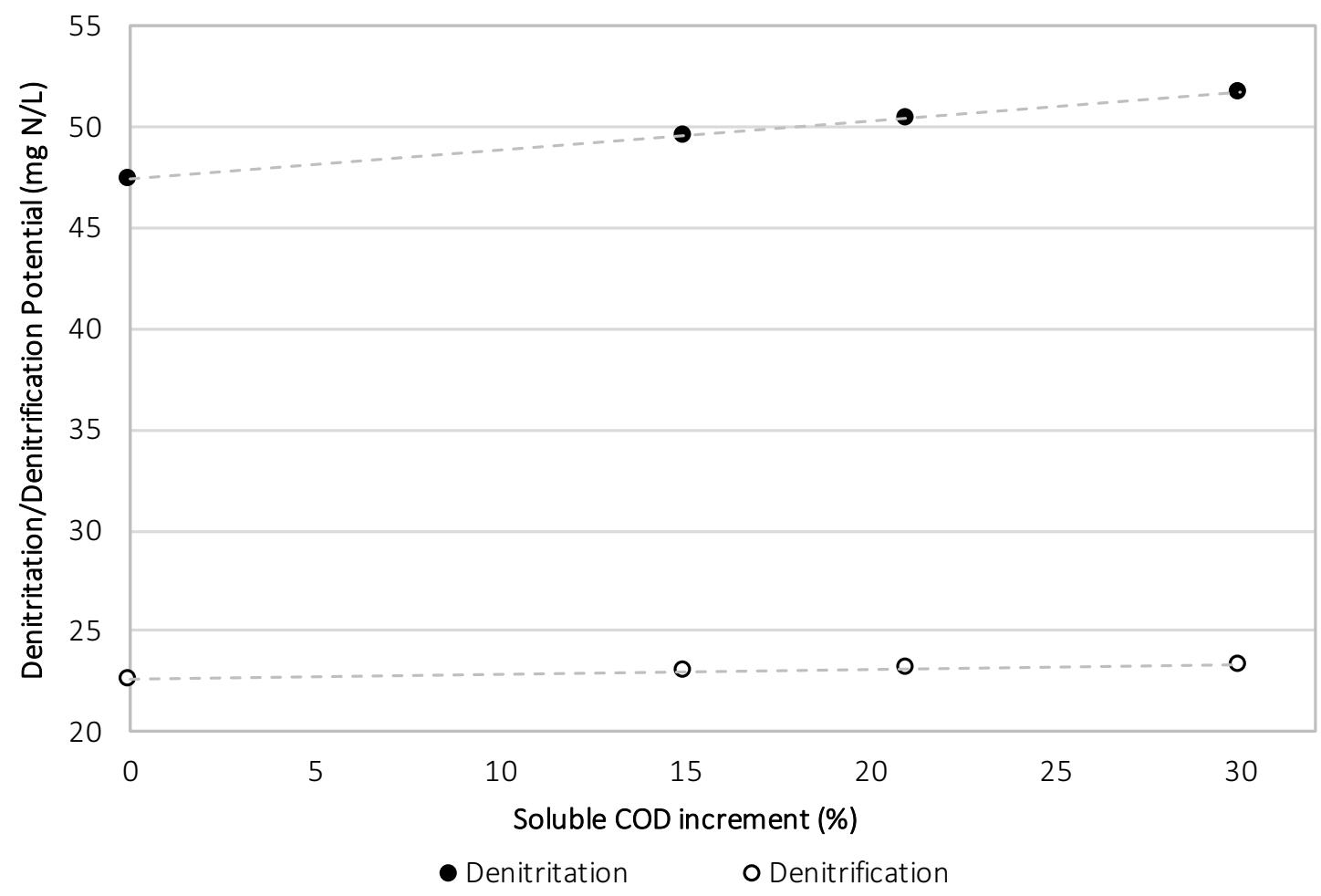

Figure 2: Relationship between the denitritation $(\bullet)$ and denitrification (o) potential depending on the amount of COD in the influent.

The addition of a by-pass to the anaerobic reactor involves other effects, which do not affect the economic feasibility of the proposed method. An important advantage of the process is the reduction of the equipment size which is translated in less initial investment in the anaerobic process (equipment and infrastructure) and also less operation costs in the membrane reactor. On the other hand, one of the weak points of this proposal is the reduction of the produced biogas because of the lower flow treated (Figure 3). This reduction implies a reduction in the amount of electric energy produced by the system (Eq.3 and Eq.4). It has to be considered that one of the most important costs in the WWTP is the electricity. So, the electric energy has to be considered as a control parameter to determine the economic feasibility of the process. So, it is analyzed the change in energy production linked to each of the proposed improvements.

In both cases presented in Figure 3, the reduction in the electric energy (Eq.3 and Eq.4) is obtained because of a reduction in the feed flow to the anaerobic reactor. So, the reduction value is linked to the flow reduction value of $5 \%, 7 \%$ and $10 \%$. 


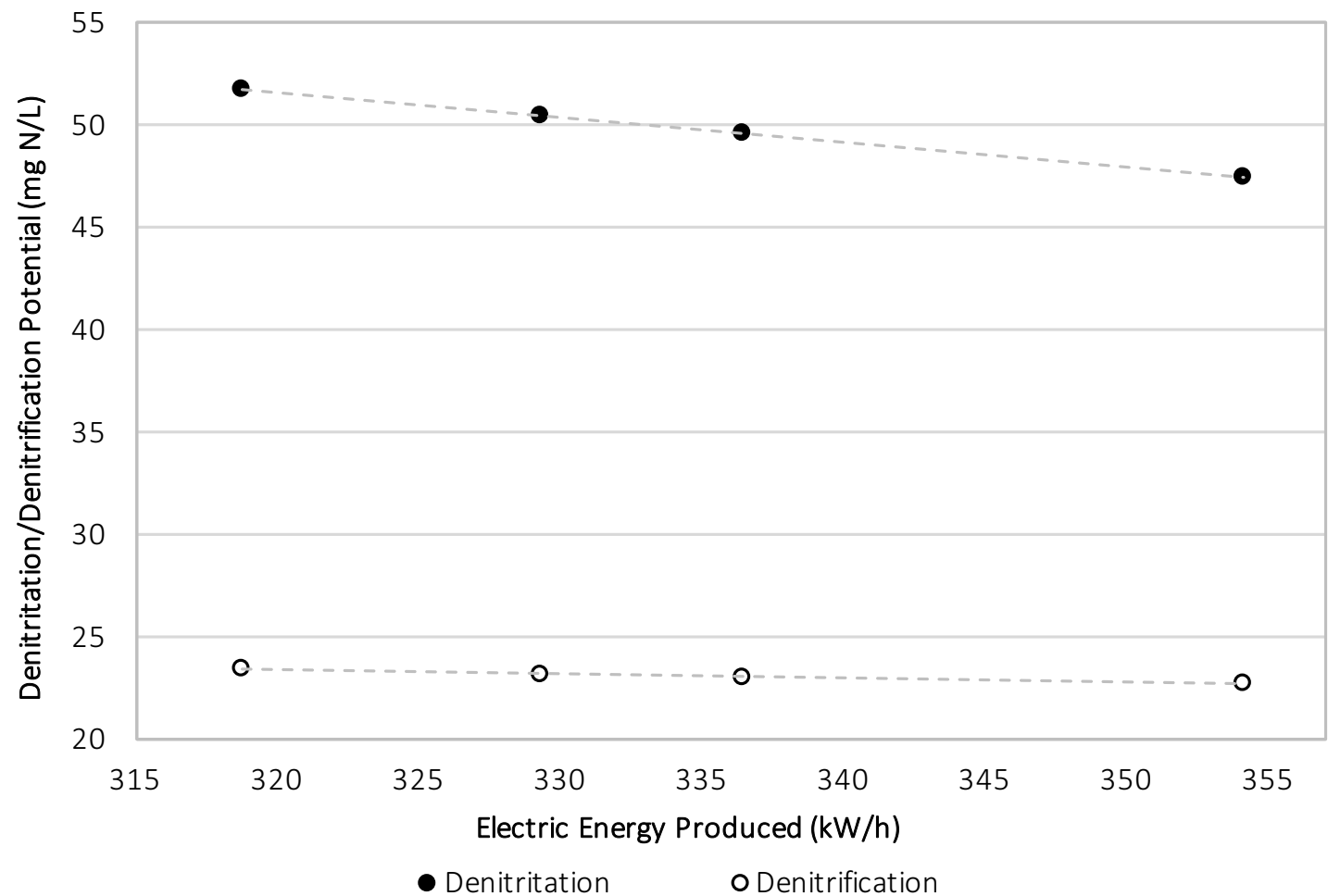

Figure 3: Relationship between the denitritation $(\bullet)$ and denitrification (o) potentials with the electric energy produced employing the biogas produced in the anaerobic process.

\subsection{Effect of the recycling of biogas}

The methane and sulfide produced as biogas in the anaerobic process can be also considered as an electron donor source ${ }^{[19,20]}$. The addition of a biogas recycle in the denitrification reactor would increase the methane and sulfide concentration inside the reactor, enhancing the nitrogen elimination capacity as nitrites or nitrates.

The simulations of this scenario considered the maximum elimination of nitrogen (final concentration of $0,10,15$ and $20 \mathrm{mg} \mathrm{N} / \mathrm{L}$ ) using as low as possible amount of biogas. The effect of biogas recycling is depicted in Figure 4 for the denitritation/denitrification process, and it was calculated following Eq.5. It can be seen that the denitritation potential (Eq.2) can be increased in $21.2 \%, 31.7 \%$ and $42.3 \%$ by recycling $4.7 \%, 7.0 \%$ and $9.3 \%$ respectively, of the total available biogas. In the case of the denitrification process, the recycled biogas flow was increased up to 15.4\%. In this case, the nitrogen elimination capacity can be increased in $44.3 \%, 66.4 \%$ and $88.5 \%$ by recycling $7.7 \%, 11.6 \%$ and $15.4 \%$ respectively, of the total available biogas, in comparison to the no recycle system. 


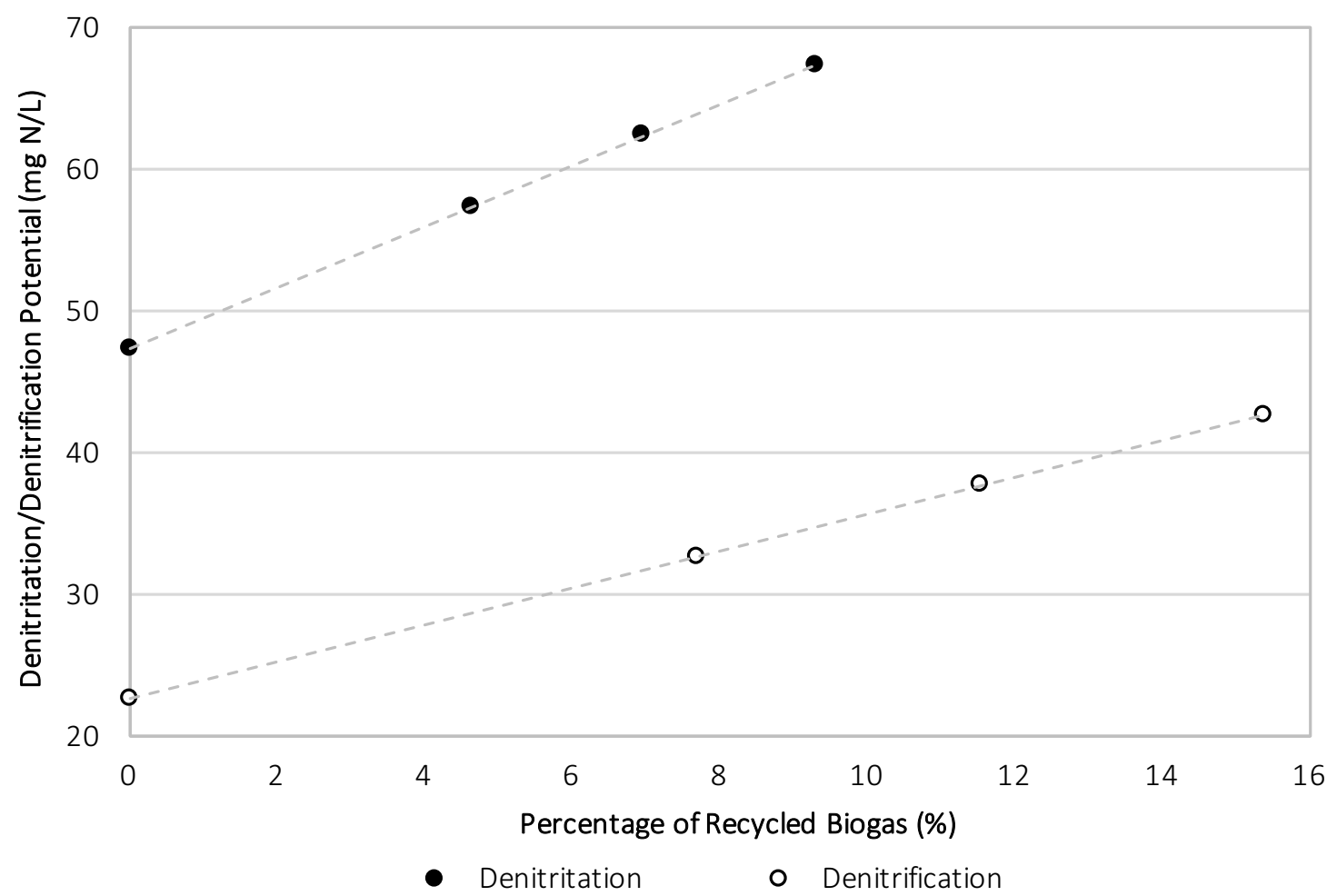

Figure 4: Relationship between the denitritation $(\bullet)$ and denitrification (o) potentials with the percentage of recycled biogas.

It has to be pointed that the cases analyzed in this section do not include the by-pass to the anaerobic reactor to increase the influent COD to the denitritation/denitrification reactor. So, the effect observed is attributed exclusively to the increment of methane and sulfide.

The increment in the recycled biogas flow diminishes the production of electric energy from the produced biogas. In Figure 5, it is depicted how the increment in the potential of denitritation and denitrification (Eq.2) affects the economic feasibility of the processes (Eq.4).

It can be seen in Figure 5 that the amount of electric energy produced in both cases is lower at higher denitritation/denitrification potentials. The highest loss of produced energy is observed in the denitrification process with reduction rates of $8.3 \%, 13.1 \%$ and $18.2 \%$. The denitritation reactor showed reduction rates of $4.9 \%, 7.5 \%$ and $10.3 \%$. 


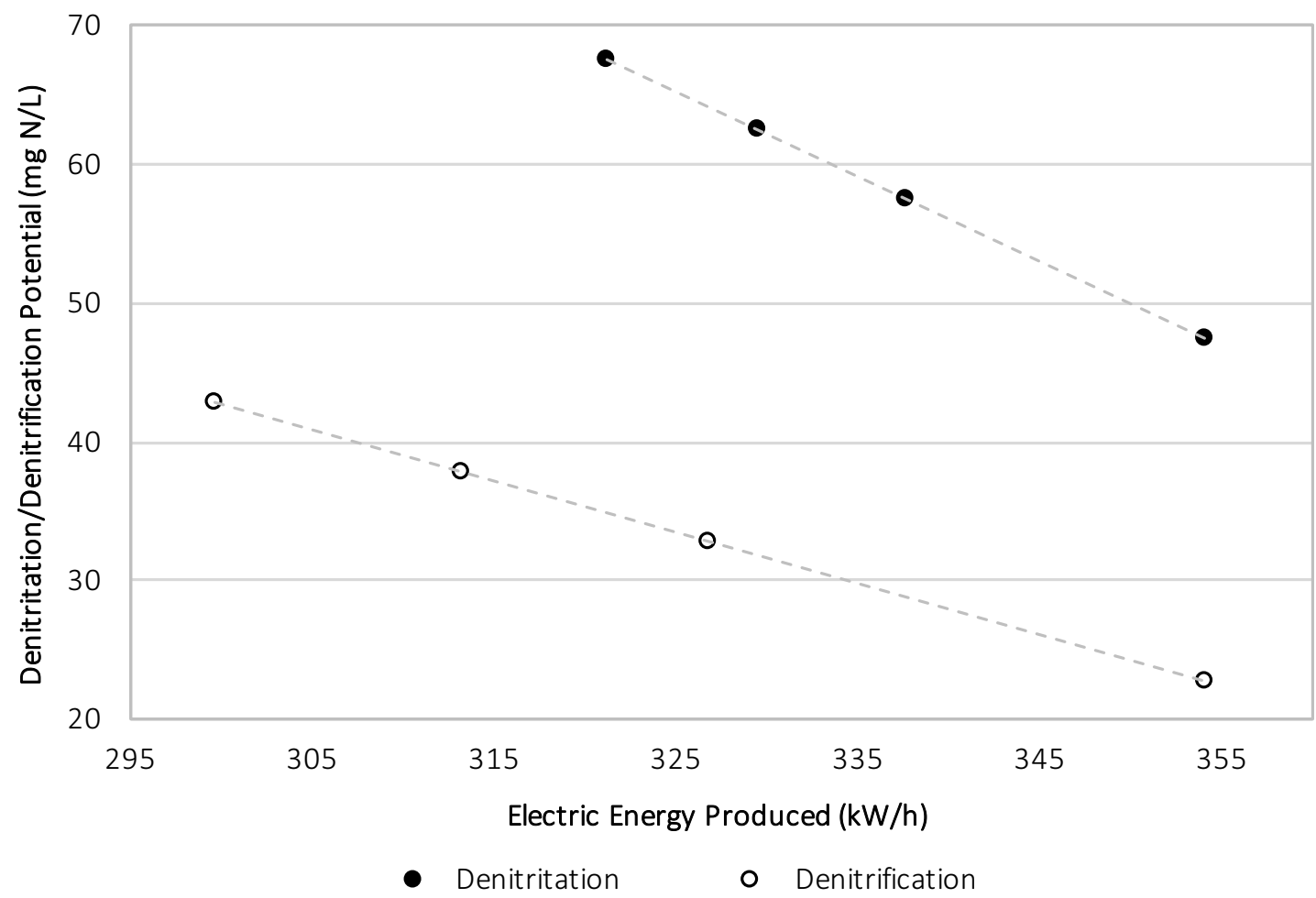

Figure 5: Relationship between the denitritation $(\bullet)$ and denitrification (o) potentials with the electric energy produced using the biogas generated in the anaerobic reactor.

\subsection{Effect of combined COD and methane}

The scenarios previously evaluated can be combined at the same time to get better results. As depicted in Figure 6, the study of the effect of both variables in the two analyzed systems shows that the increment of the available soluble COD has a higher effect on the nitrogen removal potential when the biogas addition is lower.

On the other hand, in the denitrification case, the effect of the COD is minimum, so the combined effect is mainly due to the methane. So, the combination of the two variables do not shows big changes. 


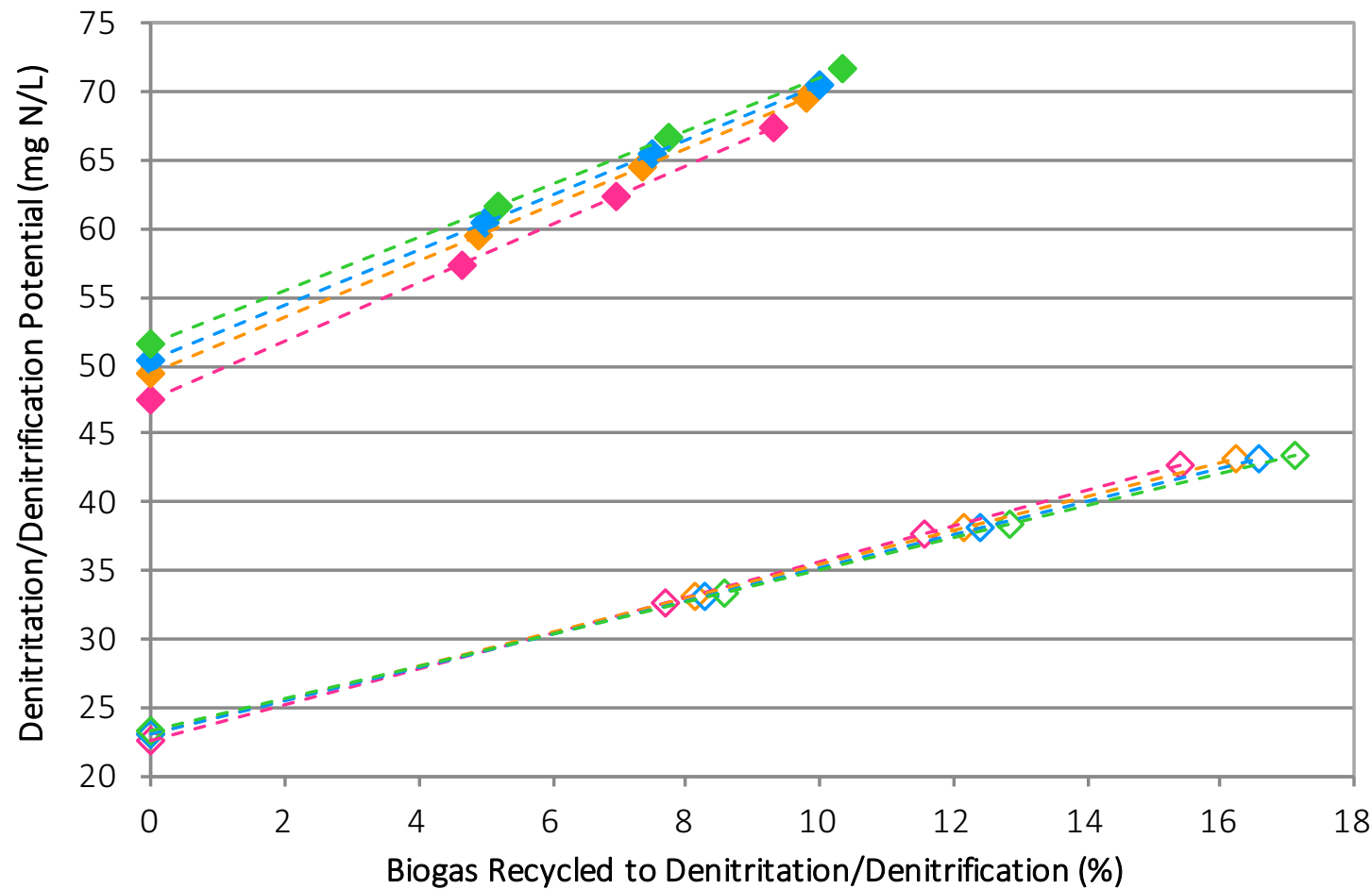

Denitritation:

- sCOD increment (0\%) • sCOD increment $(15 \%) \diamond$ sCOD increment $(21 \%) \diamond$ sCOD increment $(30 \%)$

Denitrification:

$\diamond$ sCOD increment $(0 \%) \diamond$ sCOD increment $(15 \%) \diamond$ sCOD increment $(21 \%) \diamond$ CODs increment $(30 \%)$

Figure 6: Relationship between the denitritation (a) and denitrification (b) potentials with the percentage of biogas recycled in function of the soluble COD increment.

Both strategies imply the reduction in the energy production from biogas. So, their combination should contemplate the addition of this reduction (depicted in Figure 7). In the denitrification case, considering that the methane/nitrate ratio is higher than the methane/nitrite ratio, the needs of biogas will be higher to reach certain nitrogen removal, so, the energy balance is less favorable. 


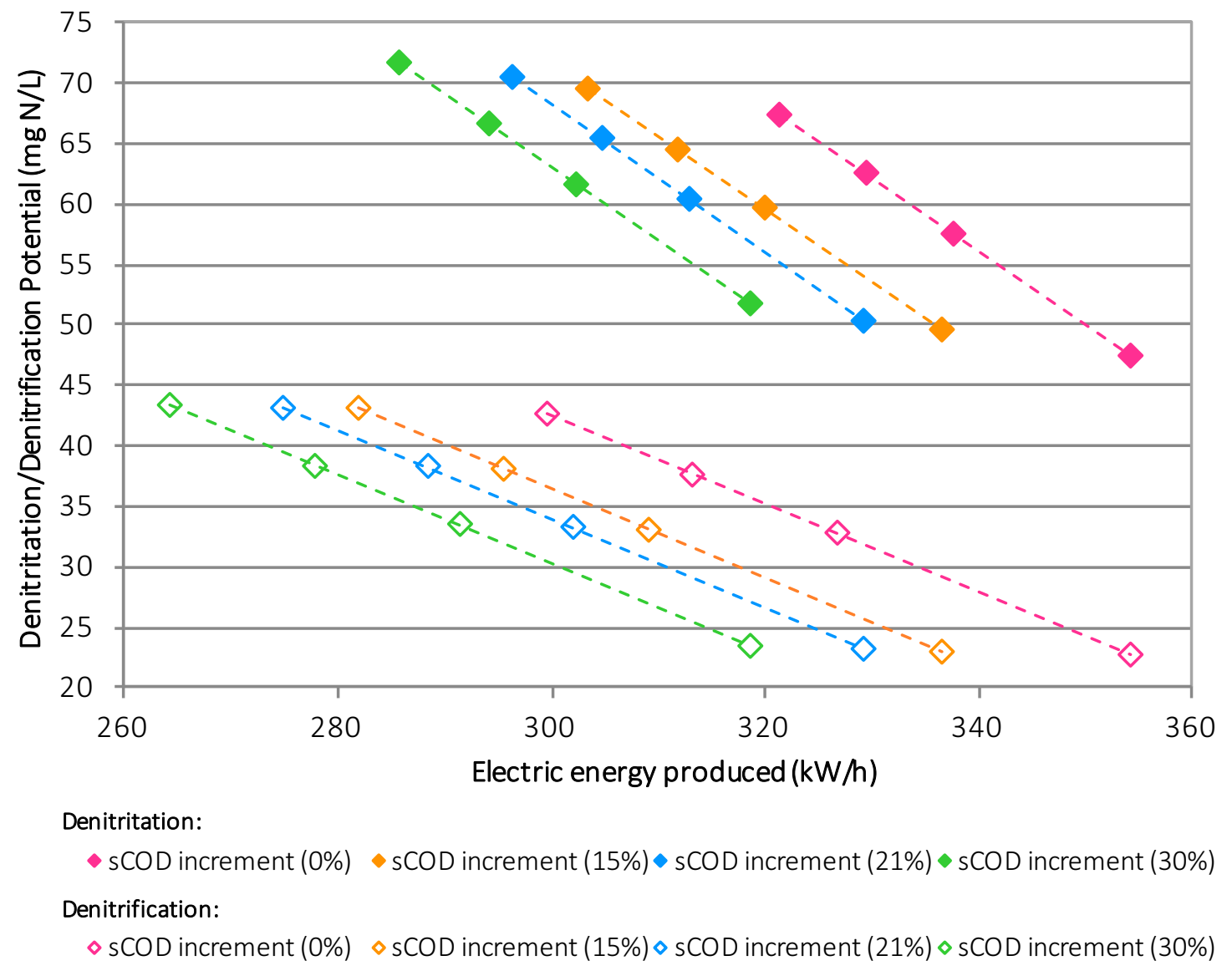

Figure 7: Relationship between the denitritation (a) and denitrification (b) potentials with the produced electric energy.

\subsection{Economic evaluation}

Once the nitrogen removal capacity of both systems was evaluated, the optimum option should be decided. The key for deciding that is the choice between the analyzed scenarios that maximizes the nitrogen elimination (nitrates/nitrites to nitrogen) and keeps as high as possible the electric energy production from biogas. In any case, respecting the quality required for the effluents by the Law.

The maximum concentration of nitrates and nitrates that can be reduced (considering the potentials evaluated above) depends on the flow of the recycle stream. This recycling flow will affect also the design of the next stages of the process.

The simulation was done considering the following parameters:

- Feed Flow to the process: $20.000 \mathrm{~m}^{3} / \mathrm{d}$.

- Ammoniacal nitrogen concentration: $95 \mathrm{mg} \mathrm{N} / \mathrm{L}$. 
- Ammoniacal nitrogen conversion to nitrites/nitrates: 95\%.

- Concentration of nitrites/nitrates in the effluent: $\leq 8 \mathrm{mg} \mathrm{N} / \mathrm{L}$.

Assuming these working conditions, the optimum process will be composed of: an anaerobic biological reactor without derivation of the flow; followed by a denitritation system with a recycling of biogas of $20.5 \%$ respect to the total amount of produced biogas; and finally, a nitritation stage with a recycling of 1.2 time the flow of the influent.

The working option employing the stages of complete nitrification and denitrification were discarded because its needs for aeration are high, which is translated in an increment in the overall energetic costs of $12 \%$.

Once the optimum working line was decided, it was done and economic study of the costs associated with the selected process. It was also included a comparison to a WWTP with the same treatment capacity, which will be used to determine the viability of the proposed process. The operation schemes of the two evaluated facilities are depicted in Figures 8 and 9.

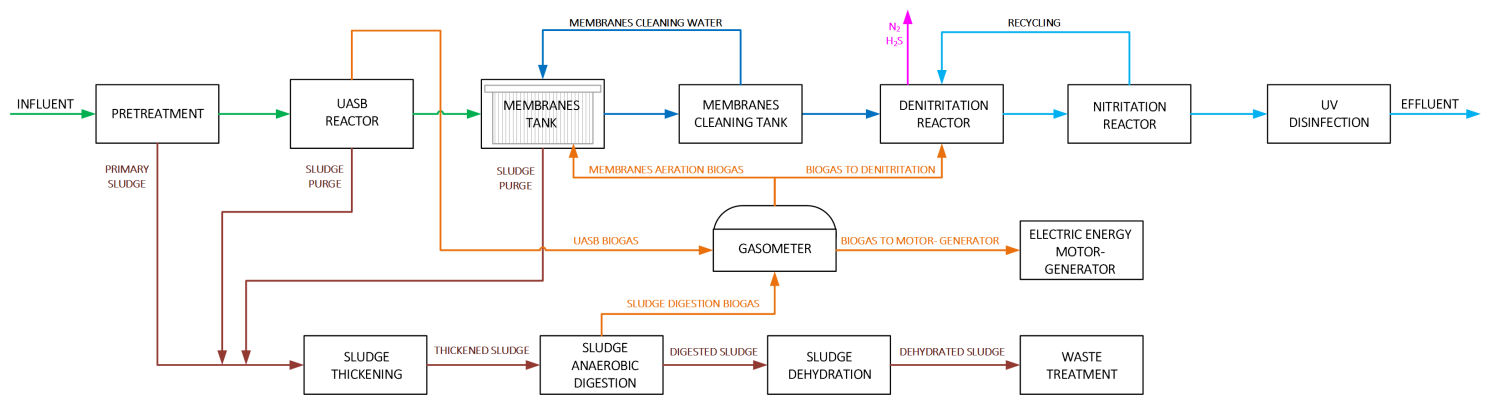

Figure 8: Schema of the proposed facility.

The schema presented in Figure 8 is composed of the following process units:

- Water line: pretreatment, biological anaerobic reactor with membrane tank, membrane cleaning deposit, denitritation reactor, nitritation reactor and disinfection with UV.

- Sludge line: thickening, anaerobic digestion, dehydration and residues treatment.

- Gas line: gasometer and electric energy generation. 


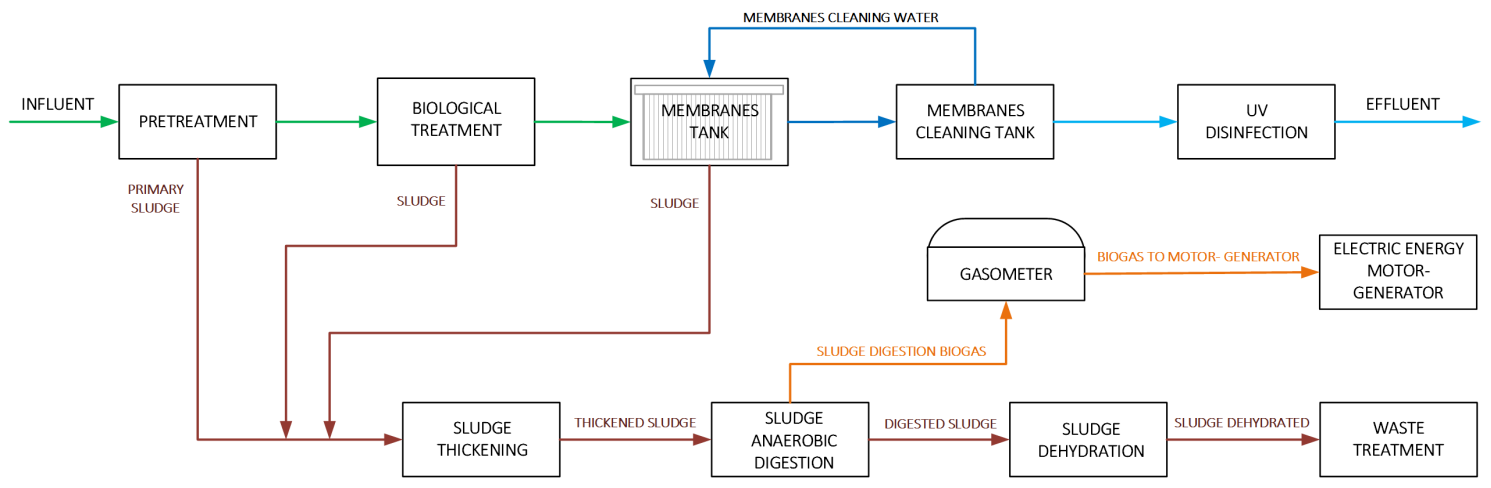

Figure 9: Schema of a conventional WWTP with MBR treatment.

The schema presented in Figure 9, for a conventional WWTP is composed of:

- Water line: pretreatment, biological anaerobic reactor with membrane tank, membrane cleaning deposit and disinfection with UV.

- Sludge line: thickening, anaerobic digestion, dehydration and residues treatment.

- Gas line: gasometer and electric energy generation.

The design data to carry out the economic study are listed as follows:

- Design flow: $20.000 \mathrm{~m}^{3} / \mathrm{d}$.

- A conventional WWTP was taken as reference with membrane bioreactor (MBR) technology.

- The employed membranes in the MBR system, conventional plant as well as in the AnMBR were assumed to be supplied by General Electric (membranes of PVDF, nonionic and hydrophilic) ${ }^{[21]}$. The configuration of the membrane was enforced fiber with flow direction out-in and a nominal pore diameter of 0.04 microns. The commercial membrane employed is "Zeewed 500".

- The initial investment cost affects the amortization of the facility. It was considered a period of 50 years for building and 20 years for equipment as amortization time.

Cost analysis are based on actual costs. The fixed and variable costs of the facility were studied in an independent way. In the fixed costs are include: the amortization of the facility, the fixed cost of energy, the process control, the maintenance and conservation, salaries and other costs such as insurances, taxes or rents.

The fixed costs of both facilities are quite similar, being a little lower the costs associated to the conventional treatment. The main reason of that, is the amortization of the facilities (Figure 10). 

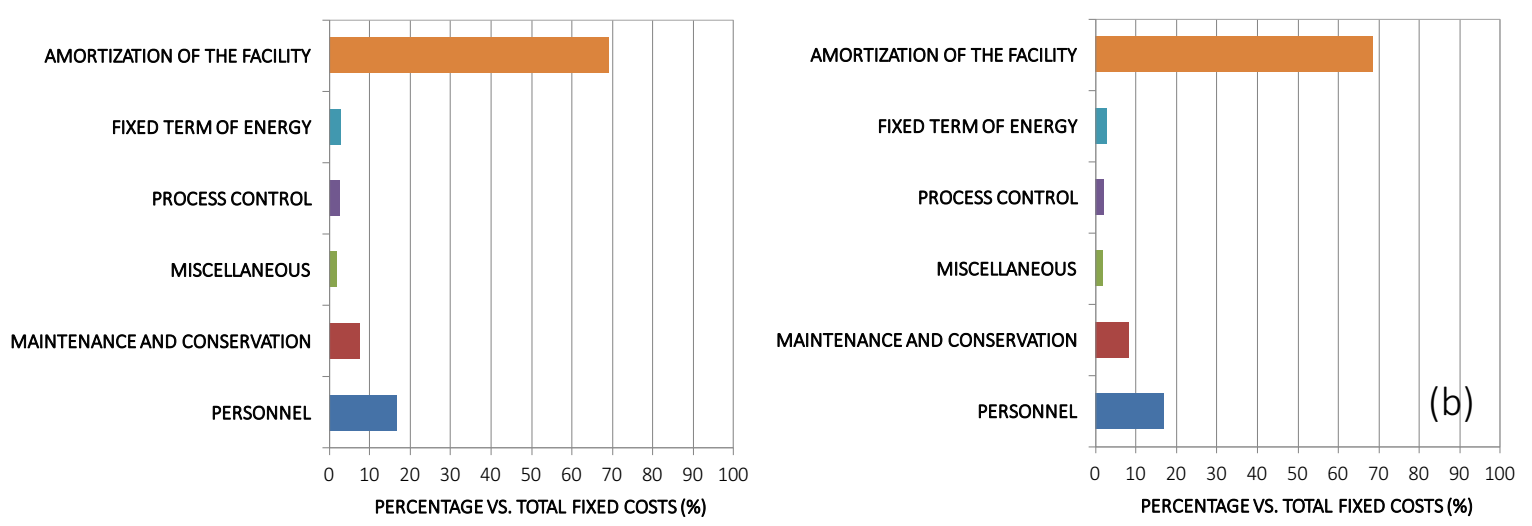

Figure 10: Fixed costs including the amortization of the facility with the proposed process (a) and conventional plant (b).

The cost associated to the amortization (the gradual charging to expense of the cost over the useful life of the asset) of the facility is the(bi)ghest amount of cost in the total costs. These costs are higher for the proposed facility (Figure 10a) than for the traditional (Figure 10b). The main reason of that, is the required building of two extra stages, the denitritation and nitritation, which are not included in a traditional process. In this sense, the increment in the biogas production obtained with the proposed technology in the anaerobic reactor make it necessary to install bigger equipment in the gas line than in the traditional facility. Nevertheless, in comparison to the aerobic systems, the anaerobic systems produce less amount of sludge, so the equipment involved in this stage will be smaller and so, the construction costs.

The rest of the costs are similar in both working procedures. A small difference can be notice in the section of process control. In the proposed process, this cost is higher because there are three additional stages that should be controlled.

After the costs associated to the amortization in the fixed costs, the personnel cost followed by the maintenance and facility conservation are the highest fixed costs associated to the facilities, as can be seen in Figure 11. 

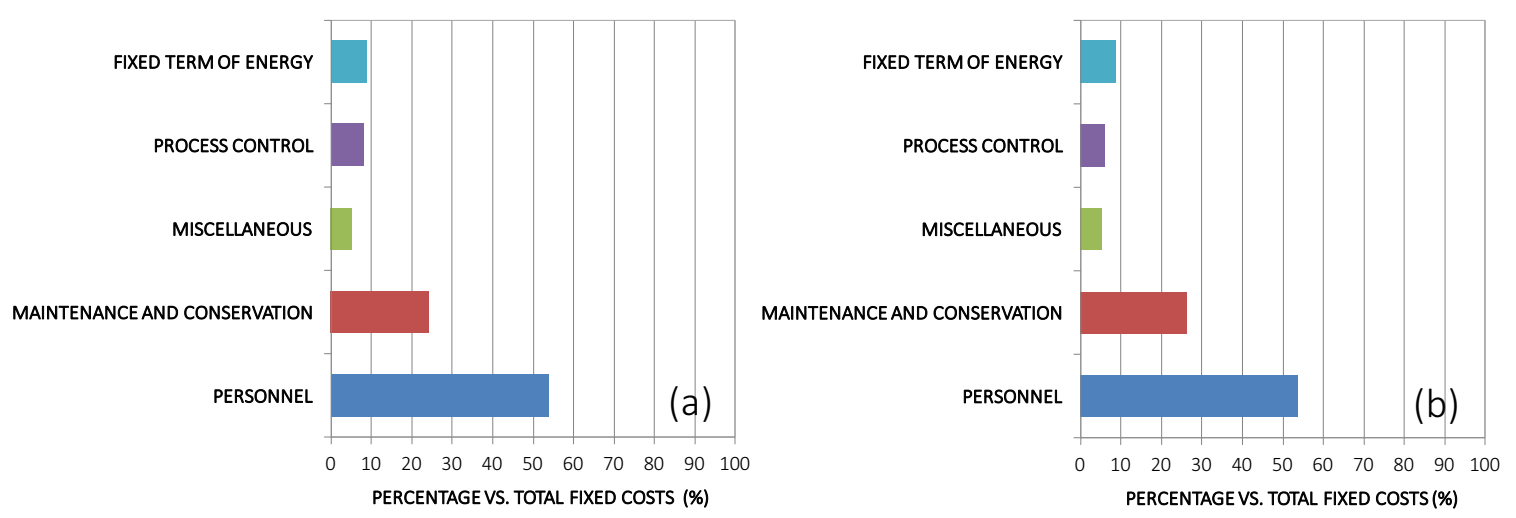

Figure 11: Fixed costs excluding the amortization costs for the proposed process (a) and a conventional WWTP (b).

The variable costs include the replacement of membranes (the membranes of the biological process as well as the replacement of the UV disinfection lamps), the consumption of electric energy, transportation and discharge of residues and consumption of chemical reagents.

The variable costs (Figure 12) associated to the proposed process are slightly lower than those required in the traditional process. The consumption of electric energy in one of the main reasons of this cost difference. It should be mentioned that the electric energy consumption in the proposed method is higher but the generation of electricity is also higher. It should be noted that in the proposed method there are two sources of biogas, the membrane anaerobic reactor and the anaerobic digestion of sludge. In the conventional option there is only one source of biogas, the anaerobic digestion of sludge. So, the overall energy balance shows lower energy consumption for the proposed method than the conventional one.

The other important cost to analyze is the transportation and discharge of the residues. Focusing in the sludge production and considering that the sludge production in an anaerobic reactor is lower than in an aerobic one, the proposed method has the advantage over the conventional process of reducing the transportation and discharge costs. 

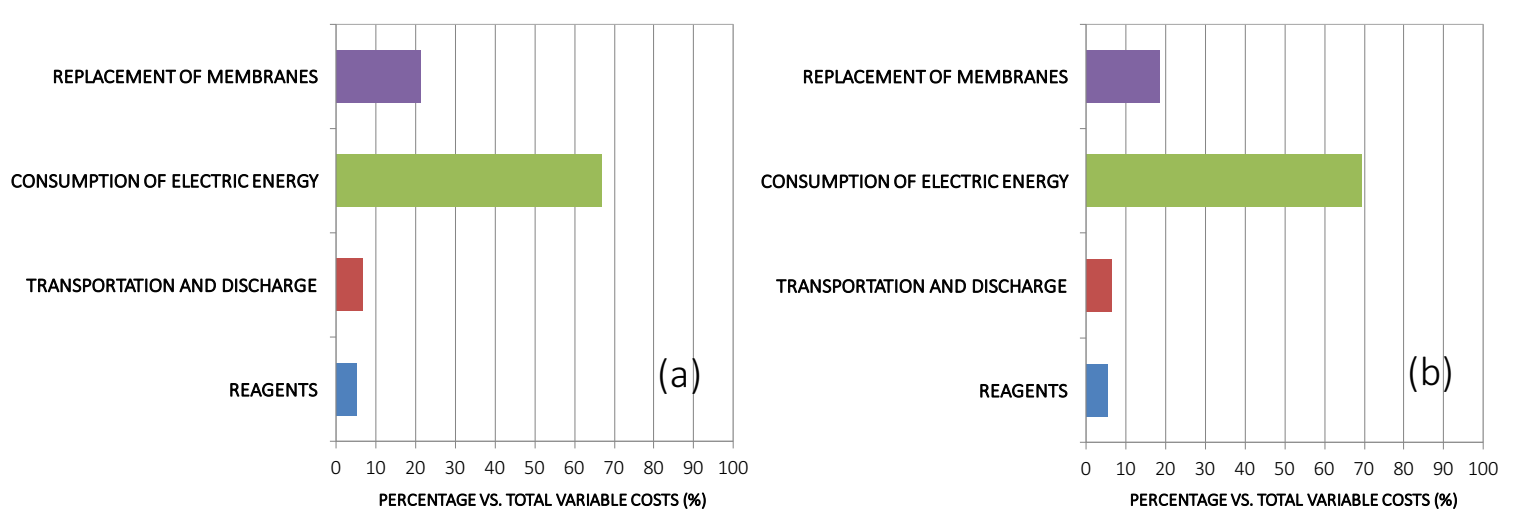

Figure 12: Variable costs of the proposed facility (a) and the conventional WWTP (b).

\section{CONCLUSIONS}

The increment in the available soluble COD to carry out the process does not imply the same amount of increments in the denitritation and denitrification potentials. A COD increment of $15 \%, 21 \%$ and $30 \%$ means an increase in the denitritation potential between $4.5 \%, 6.3 \%$ and $9 \%$, the denitrification potential is increase between $1.6 \%, 2.2 \%$ and $3.2 \%$ with the same change in COD.

The use of a by-pass to the anaerobic reactor to increase the soluble COD in the denitritation reactor provokes a reduction in the amount of biogas produced which affects directly to the economic viability of the proposed process.

It was demonstrated that the increment of available methane in the reactor is the most promising alternative to increase the denitrification/denitritation potential in both aspects: technical and economical.

When comparing to a conventional WWTP, it was concluded that the fixed costs of both alternatives are similar. However, the proposed method in this research work shows slightly higher costs than the conventional process. These differences are associated mainly to the amortization of the facility and equipment and the addition of new stages to the process. In terms of variable costs, the proposed method showed lower costs than the conventional process. In this case, the difference lies in the higher amount of produced energy and lower requirement of residues accommodation. 


\section{ACKNOWLEDGEMENTS}

The authors thank the company Cadagua S.A., the European Regional Development Fund, and the project IPT-2011-1078-310000, and the INNPACTO 2011 program of the Ministry of Economy and Competitiveness for the technical and financial support. The authors acknowledge Dr. Jorge Ignacio Pérez Pérez (Department of Civil Engineering, University of Granada). 


\section{References}

1. H. Gao, Y. D. Scherson and G. F. Wells, Towards energy neutral wastewater treatment: methodology and state of the art, Environmental Science: Processes \& Impacts, 2014, 16(6), p.1223-1246.

2. M. Zessner, C. Lampert, H. Kroiss and S. Lindtner, Cost comparison of wastewater treatment in Danubian countries, Water science \& Technology, 2010, 62(2), p.

3. S. Evangelisti, P. Lettieri, D. Borello and R. Clift, Life cycle assessment of energy from waste via anaerobic digestion: A UK case study, Waste Management, 2014, 34(1), p.226-237.

4. M. Grosso, C. Nava, R. Testori, L. Rigamonti and F. Viganò, The implementation of anaerobic digestion of food waste in a highly populated urban area: an LCA evaluation, Waste Management \& Research, 2012, 30(9 suppl), p.78-87.

5. L. Appels, J. Baeyens, J. Degrève and R. Dewil, Principles and potential of the anaerobic digestion of waste-activated sludge, Progress in energy and combustion science, 2008, 34(6), p.755-781.

6. J. Gouveia, F. Plaza, G. Garralon, F. Fdz-Polanco and M. Peña, Long-term operation of a pilot scale anaerobic membrane bioreactor (AnMBR) for the treatment of municipal wastewater under psychrophilic conditions, Bioresource Technology, 2015, 185225 233.

7. W. Zeng, L. Li, Y. Yang, S. Wang and Y. Peng, Nitritation and denitritation of domestic wastewater using a continuous anaerobic-anoxic-aerobic (A2O) process at ambient temperatures, Bioresource Technology, 2010, 101(21), p.8074 - 8082.

8. S. Aslan and M. Dahab, Nitritation and denitritation of ammonium-rich wastewater using fluidized-bed biofilm reactors, Journal of Hazardous Materials, 2008, 156(1-3), p.56-63.

9. W. Zeng, X. Wang, B. Li, X. Bai and Y. Peng, Nitritation and denitrifying phosphorus removal via nitrite pathway from domestic wastewater in a continuous MUCT process, Bioresource Technology, 2013, 143187-195.

10. B. Moraes and E. Foresti, Determination of the intrinsic kinetic parameters of sulfideoxidizing autotrophic denitrification in differential reactors containing immobilized biomass, Bioresource Technology, 2012, 104250-256.

11. M. B. de S, J. Orrú, C. de Andrade, D. Fonseca and E. Foresti, Shortcut NitrificationDenitrification Coupled With Sulfide Oxidation In A Single Reactor, J Microb Biochem Technol, 2014, 6087-095. 
12. A. Sánchez, L. Rodríguez-Hernández, D. Buntner, A. L. Esteban-García, I. Tejero and J. M. Garrido, Denitrification coupled with methane oxidation in a membrane bioreactor after methanogenic pre-treatment of wastewater, Journal of Chemical Technology \& Biotechnology, 2016n/a-n/a.

13. O. Modin, K. Fukushi and K. Yamamoto, Denitrification with methane as external carbon source, Water Research, 2007, 41(12), p.2726 - 2738.

14. S. Uemura and $\mathrm{H}$. Harada, Treatment of sewage by a UASB reactor under moderate to low temperature conditions, Bioresource Technology, 2000, 72(3), p.275-282.

15. J. Cookney, A. McLeod, V. Mathioudakis, P. Ncube, A. Soares, B. Jefferson and E. J. McAdam, Dissolved methane recovery from anaerobic effluents using hollow fibre membrane contactors, Journal of Membrane Science, 2016, 502141 - 150.

16. J. Gouveia, F. Plaza, G. Garralon, F. Fdz-Polanco and M. Peña, A novel configuration for an anaerobic submerged membrane bioreactor (AnSMBR). Long-term treatment of municipal wastewater under psychrophilic conditions, Bioresource Technology, 2015, 198510-519.

17. I. Angelidaki, L. Ellegaard and B. K. Ahring, A comprehensive model of anaerobic bioconversion of complex substrates to biogas., Biotechnology and Bioengineering, 1999, 63(3), p.363-372.

18. S. Montalvo and L. Guerrero, Tratamiento anaerobio de residuos. Producción de Biogás, Registro de la propiedad intelectual, 2003, 134.

19. J. C. Lackey, B. Peppley, P. Champagne and A. Maier, Composition and uses of anaerobic digestion derived biogas from wastewater treatment facilities in North America, Waste Management \& Research, 2015, 33(8), p.767-771.

20. A. Wellinger, J. D. Murphy and D. Baxter, The biogas handbook: science, production and applications, Elsevier, 2013.

21. General Electric Company, GE's Water \& Process Technologies, DOI: http://www.gewater.com/products/zeeweed-500-membrane.html). 
Conclusions 
The general conclusions of this PhD Thesis are presented below. The specific conclusions of each research are presented in the chapter conclusions.

In this PhD thesis has been extensively studied the process of nitrification and denitrification to remove ammoniacal nitrogen from the effluent of an AnMBR reactor that treated domestic wastewater at $18 \stackrel{\circ}{\circ}$.

A SBR process was applied to ascertain its suitability for simultaneous nitrification and denitrification. Cycle times of $12 \mathrm{~h}, 8 \mathrm{~h}$ and $6 \mathrm{~h}$ in SBR were considered in the study, and the $6 \mathrm{~h}$ cycle time was selected as the optimal for the treatment. The process was successful in an anoxic/aerobic/anoxic cycle sequence with the addition of methanol just before the second anoxic stage. Thus, it has been demonstrated that the SBR process in a single reactor at low temperature is a suitable process for the simultaneous removal of nitrogen and organic matter of a domestic wastewater with low COD with only the addition of external carbon source. The addition of methanol was a key point in the denitrification process employed as a model for the wastewater by-pass in the WWTP.

The denitrification of domestic wastewater with a low concentration of COD could be possible by using the methane and sulfide that contains the water after the anaerobic treatment. $\mathrm{NO}_{2}$ and $\mathrm{NO}_{3}{ }^{-}$were the electron acceptors, while the $\mathrm{OM}, \mathrm{CH}_{4}$ and $\mathrm{H}_{2} \mathrm{~S}$ were the electron donors. A fixed film anoxic bioreactor for partial and total denitrification was studied.

From the one hand, nitrogen removal was demonstrated obtaining a successful $\mathrm{NO}_{2}{ }^{-}$and $\mathrm{NO}_{3}{ }^{-}$elimination when the feed was $80 \mathrm{mg} \mathrm{N}-\mathrm{NO}_{x}{ }^{-} / \mathrm{L}$, except when the feeding was formed only by nitrate. In this case, the process was at the limit of the denitrification process. The optimal HRT to obtain both, denitritation and denitrification was $2 \mathrm{~h}$. The amount of methane available in the water was enough to achieve the goal being the main electron donor used with more than $70 \%$ or participation.

On the other hand, when only partial denitrification was studied in the same plant and the same HRT of $2 \mathrm{~h}$, the results demonstrated very good denitritation yields for the nitrite removal up to $75 \mathrm{mg} \mathrm{NO}{ }_{2}^{-}-\mathrm{N} / \mathrm{L}$. For high inlet concentrations of nitrite, the recirculation of the gas collected in the anoxic reactor was a successful solution, thus achieving a nitrite removal efficiency upper than $98 \%$ when the nitrite concentration in the feed was $95 \mathrm{mg} \mathrm{NO}{ }_{2}^{-} \mathrm{N} / \mathrm{L}$. Specifically, denitritation is a feasible process for the simultaneous removal of $\mathrm{NO}_{2}{ }^{-}, \mathrm{OM}, \mathrm{CH}_{4}$ and $\mathrm{H}_{2} \mathrm{~S}$ for actual wastewater and the recirculation of the gas from the anoxic reactor is an efficacious system to enhance the nitrites removal. 
A denitrification/nitrification integrated system with a short HRT of $2 \mathrm{~h}$ for the anoxic bioreactor and $4 \mathrm{~h}$ for the aerobic one was studied. The plant was operated to examine the effect of the nitrate recycling and the $C O D / N$ ratio on the nitrogen and the remaining organic matter removal. The successful results of the system to remove COD and TN from domestic wastewater after anaerobic treatment could be achieved mainly due to the addition of methanol. Methanol increased the molar ratio of $\mathrm{C} / \mathrm{N}$ in the wastewater accelerating the nitrification and denitrification rates, being the key point in the nitrogen removal. On the other hand, despite nitrate recycling did not suppose a significant improvement in the process, it improved the homogeneous distribution of microbial communities in the reactors increasing the removal efficiency of nitrogen. As result of the combined impacts, it was obtained an effluent that met the requirements of wastewater discharge, in terms of organic matter and nitrogen content.

It is noteworthy that instead of the addition of methanol, the enhancement of the $C / D$ ratio can be made (at least partially) by bypassing part of the feedstream from a point before the anaerobic treatment to another point in the end of this reactor. In this way, it is provided to the denitrification process a feed with a higher concentration in organic matter.

Finally, a techno-economical feasibility of the domestic wastewater treatment consisting in an anaerobic membrane reactor followed by a nitrogen removal plant was simulated. Different scenarios have been assessed changing the concentration of the involved components and evaluating their effect on the nitrogen elimination capacity as well as the ability to produce biogas in the anaerobic treatment. The increment in the available soluble COD to carry out the process implied more increment in the denitritation potential than in the denitrification one. The use of a by-pass to the anaerobic reactor to increase the soluble COD in the denitritation reactor provokes a reduction in the amount of biogas produced which affects directly to the economic viability of the proposed process. It was demonstrated that the increment of available methane in the reactor is the most promising alternative to increase the denitrification/denitritation potential in both aspects: technical and economical.

Then, the most promising scenario was studied in detail and it was compared to the costs associated to the WWTP with a biological anaerobic treatment using a MBR system. When comparing an AnMBR+Denitritation/Nitritation plant to a conventional WWTP, it was concluded that the fixed costs of both alternatives are similar. However, the proposed method in this research work shows slightly higher costs than the conventional process. These differences are associated mainly to the amortization of the facility and equipment and the addition of new stages to the process. In terms of variable costs, the proposed method showed lower costs than 
the conventional process. In this case, the difference lies in the higher amount of produced energy and lower requirement of residues accommodation. The results indicated that the proposed process is feasible since the fixed and variables costs of both treatment plants.

\section{Future Work}

From the studies developed in this PhD, it can be concluded that the field of nitrogen removal in domestic wastewater is an interesting area with several interesting topics to address. The main topics to be developed in the research of nitrogen removal are presented in the next paragraphs.

It was observed that the $\mathrm{C} / \mathrm{N}$ ratio in the feed is one of the most critical parameters that can affect directly the biological nitrogen removal efficiency. As the amount of biodegradable organic carbon of domestic wastewater after anaerobic treatment is limited, the addition of external carbon sources such as methanol, often becomes necessary for achieving highefficiency BNR. It would be interesting to evaluate the effect of increasing the $\mathrm{C} / \mathrm{N}$ ratio using the mixing of the anaerobic reactor effluent and the raw feed. That is bypassing part of the feedstream from a point before the anaerobic treatment to another point in the end of this reactor. In this way, it is provided to the denitrification process a feed with a higher concentration in organic matter.

In the denitrification/nitrification integrated plant (Chapter 6) it was no possible to achieve nitritation in the aerobic reactor. Reducing the aeration to provide less DO in the reactor, or the HRT not only did not increased the nitrite production, but nitrate yield got worse. It would be important to study the way to reach partial nitritation to shortcut the denitrification reactions.

Methane and sulfide from anaerobic biogas was considered as an electron donor source. Based on the results obtained in Chapter 5, recycling of the gas collected in the anoxic reactor was a successful solution to achieve high nitrite removal efficiency for feed concentrations of 95 $\mathrm{mg} \mathrm{NO}_{2}-\mathrm{N} / \mathrm{L}$. The gas collected contained desorbed methane and it can be used for denitrify by its recycling. When the integrated system was performed this proceeding was not possible to carry out because most of the methane remained occluded in the liquid stream at low temperatures. It would be relevant to find the way to enhance the methane desorption to be able of collect it in the top of the anoxic reactor to recirculate it, improving the denitrification yields.

Another way of operation that allows the use of sulfide and methane from the biogas as electron donor source, is the addition of the anaerobic biogas in the denitrification reactor. The 
biogas would increase the methane and sulfide concentration inside the reactor, and the nitrite/nitrate removal capacity would also increase. 


\section{Agradecimientos}

Acknowledgements 
En primer lugar quiero agradecer a María su labor de dirección. Su apoyo y confianza en mi trabajo, así como su capacidad para guiar mis ideas han sido un aporte invaluable, no solamente en el desarrollo de la tesis, si no también en mi formación como investigadora.

Quiero agradecer a la Universidad de Valladolid, al Ministerio de Economia y Competitividad de España y a la empresa Cadagua S. A., por haberme brindado la oportunidad y financiación de integrarme al sistema de investigación.

A todo el Departamento de Ingeniería Química y Tecnología del Medio Ambiente de la UVa por formarme como profesional. A Mar, Polanco, Pana, Dani, Araceli...

Quisiera expresar mi más sincero agradecimiento a Alicia Gómez González, por su importante aporte y participación activa en el desarrollo de esta tesis. Debo destacar por encima de todo su disponibilidad, dedicación y confianza.

A mis compañeros y amigos del grupo de investigación, los cuales han sido y seguirán siendo parte importante en mi vida: Rebeca, leva, Natalia, Isra, Juan Carlos, Osvaldo, Alma, Sara, Dimas, Inés... Por el buen ambiente en el laboratorio y calidad en el desempeño de su trabajo. En especial a Jaime, Joao, Roberto, por echarme una mano siempre que lo he necesitado.

Gracias a Anita, Begoña, Flor, Miriam, Cynthia, Sheila, Laura, Vito, Rebeca, Teresa ... por compartir tantos momentos dentro y fuera del departamento, por su amistad.

A mis amigas de Villambroz y de Palencia... por ser tan divertidas y ser un gran apoyo.

A mi familia. A mis padres, gracias por haber sido la guía en el camino de la vida, por haberme ayudado a levantar después de los tropiezos, por dármelo todo sin condiciones. Soy lo que soy gracias a vosotros. Gracias papá, porque animarme a empezar el doctorado. Estés donde estés me guías y sé que cuidas de tus chicas, nuestro ángel de la guarda. Gracias mamá, por ser la persona más fuerte que conozco, por estar siempre ahí y animarme siempre. Gracias Virginia, por tu generosidad, cariño y amistad. En definitiva, gracias por ser mi hermana y por haberme dado una sobrina tan preciosa, Carla, que trajo la luz en la oscuridad. Gracias familia por vuestro amor incondicional. No habría llegado hasta aquí sin vosotros.

Quiero agradecer a Danilo, por su amor, su cariño, su apoyo, su ánimo, su gran ayuda en la vida personal y profesional... y su entusiasmo en conseguir que llegara esta tesis. Gracias por ser mi otra mitad. 
